\author{
UNIVERSIDADE DE SÃO PAULO \\ ESCOLA DE COMUNICAÇÕES E ARTES
}

RODRIGO CAMPOS DE OLIVEIRA

\title{
OLHAR EM PRIMEIRA PESSOA \\ Uso contemporâneo da câmera subjetiva no cinema de ficção
}

São Paulo

2016 
RODRIGO CAMPOS DE OLIVEIRA

\section{OLHAR EM PRIMEIRA PESSOA \\ Uso contemporâneo da câmera subjetiva no cinema de ficção}

Dissertação de mestrado apresentada à Escola de Comunicações e Artes da Universidade de São Paulo para obtenção do título de Mestre em Meios e Processos Audiovisuais

(versão corrigida)

A versão original se encontra disponível na Biblioteca da ECA e na Biblioteca Digital de Teses e Dissertações da USP

Área de concentração: Audiovisual

Orientadora:

Prof $^{a}$ Dra Patricia Moran Fernandes 
Autorizo a reprodução e divulgação total ou parcial deste trabalho, por qualquer meio convencional ou eletrônico, para fins de estudo e pesquisa, desde que citada a fonte.

Catalogação na Publicação

Serviço de Biblioteca e Documentação

Escola de Comunicações e Artes da Universidade de São Paulo

Dados fornecidos pelo(a) autor(a)

Oliveira, Rodrigo Campos de.

Olhar em primeira pessoa: Uso contemporâneo da câmera subjetiva no cinema de fícção.

/ Rodrigo Campos de Oliveira -- São Paulo: R. C. Oliveira, 2016.

94 p. : il.

Dissertação (Mestrado) - Programa de Pós-Graduação em Meios e Processos Audiovisuais - Escola de Comunicações e Artes / Universidade de São Paulo.

Orientadora: Patricia Moran Fernandes

Bibliografia

1. Cinema 2. Câmera subjetiva 3. Ponto de vista

I. Fernandes, Patricia Moran II. Título.

CDD 21.ed. - 791.43 
Nome: OLIVEIRA, Rodrigo Campos de

Título: OLHAR EM PRIMEIRA PESSOA: Uso contemporâneo da câmera subjetiva no cinema de ficcão.

Dissertação de mestrado apresentada à Escola de Comunicações e Artes da Universidade de São Paulo para obtenção do título de Mestre em Meios e Processos Audiovisuais.

Aprovado em:

\section{Banca Examinadora}

Prof. Dr. Instituição:

Julgamento: Assinatura:

Prof. Dr. Instituição:

Julgamento: Assinatura:

Prof. Dr. Instituição:

Julgamento: Assinatura:

Prof. Dr. Instituição:

Julgamento: Assinatura:

Prof. Dr. Instituição: Julgamento: Assinatura: 
Para Barbara, Cecilia, Crea e Vano 


\section{AGRADECIMENTOS}

Agradeço ao espírito generoso de todos que contribuiram direta e indiretamente para esta pesquisa.

Agradeço a Patricia Moran pela orientação e interesse na pesquisa. Agradeço a Ilana Feldman, Ismail Xavier, Dora Longo Bahia pelas críticas e ideias generosas em suas participações nas bancas examinadoras.

Agradeço a CAPES pela bolsa na fase de conclusão da pesquisa.

Agradeço às conversas ricas com Alexandre Souza, Almir Almas, Andréa Scansani, Branca de Oliveira, Carlos Fajardo, Carolina Berger, Carolina Gonçalves, Dora Longo Bahia, Ivan Vilela, Marco Giannotti, Mário Ramiro, Maurício Trentin, Mônica Tavares, Priscilla dos Santos, Luiz Renato Pera, Rogério Salatini, Rogério Schlegel, Thiago Mendes, professores e amigos que me ajudaram a entender e situar-me em uma pesquisa acadêmica. Sincera gratidão a todos.

Agradeço a Eduardo Santos Mendes e a Marcus Bastos, pela força e confiança.

Agradeço aos meus familiares, Pai, Mãe, Barbara, Zé Du, Cecilia, pelo carinho, pelo suporte, pelo amparo, pela paciência, enfim... Pleno coração!

Agradeço ao Luan, ao Dimitri, ao Francisco Otto e ao Tito por serem pessoas lindas que enchem minha vida de força e alegria. 


\title{
RESUMO
}

A câmera subjetiva abrange o ponto de vista, em suas múltiplas implicações narrativas, enunciativas, audiovisuais. À sua crescente presença no audiovisual contemporâneo correspondem expansões de seus sentidos comumente relacionados à linguagem clássica narrativa cinematográfica e a uma normatividade que restringe seu uso sistemático. Novos usos da câmera subjetiva associam novos fatores e novas funções dentro do cinema, relacionando técnicas e tecnologias com resultados estéticos. Esta pesquisa investiga a câmera subjetiva como recurso de linguagem e de estilo audiovisual que movimenta variáveis entre a espectatorialidade e o filme.

Palavras-chave: câmera subjetiva, ponto de vista, narrativa audiovisual

\begin{abstract}
Subjective camera embraces point of view, in several narrative, enunciative and audiovisual implications. The sense commonly related to classical cinema narrative language becomes expanded with new approaches of subjective camera in contemporary works, breaking the rules that restrain its systematic utilization. New usage of subjective camera links new functions and new elements inside cinema, connecting technologies and technics with aesthetics results. This research examines subjective camera as an audiovisual stylistic feature that crosses film language and spectatorship.
\end{abstract}

Keywords: subjective camera, point of view, audiovisual narrative 


\section{SUMÁRIO}

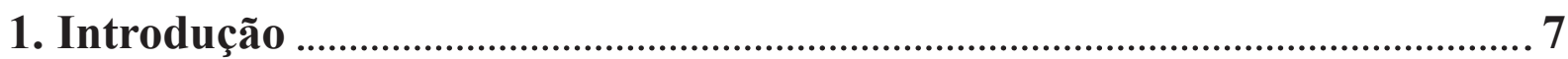

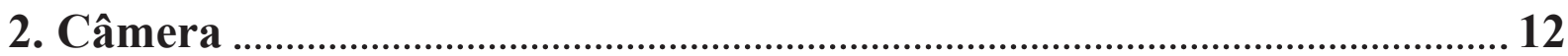

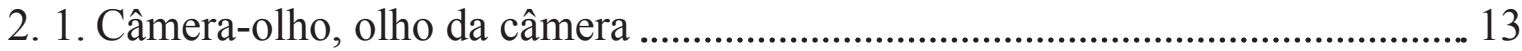

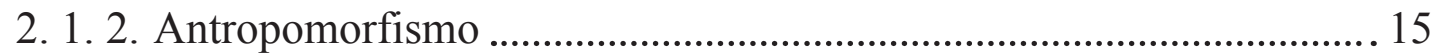

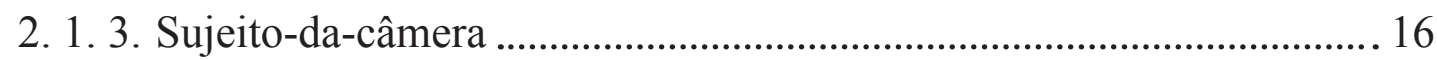

2. 1. 4. Identificação ……………………………………………………………... 17

2. 1. 5. Ponto de vista e ponto de escuta ............................................................... 19

2. 2. Câmera subjetiva e antropomorfismo ............................................................... 21

2. 2. 1. A Dama do Lago ..................................................................................... 21

2. 2. 2. La femme défendue …………………………………………………....... 25

2. 2. 2. Maniac, Peeping Tom ………………………………………………... 30

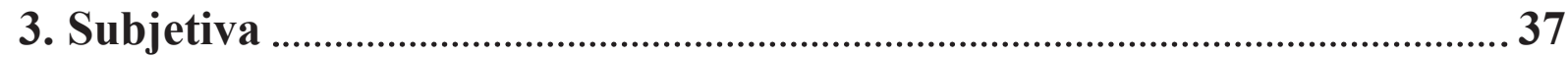

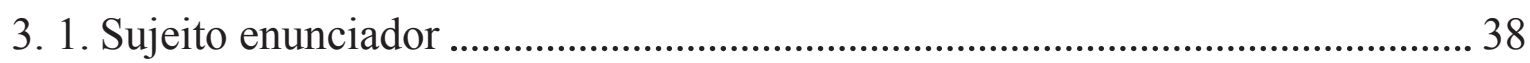

3. 1. 1. Narratologia, enunciação: discurso da câmera subjetiva ........................ 44

3. 1. 2. Focalização narrativa, entre literatura e cinema, o discurso de um narrador ........................................................................ 46

3. 1. 3. Pasolini e a subjetiva indireta livre …………………………………..... 50

3. 1. 4. Acontecimento, semiótica da câmera subjetiva ..................................... 52

3. 2. Sujeito expandido: $O$ Escafandro e a Borboleta e Enter the Void ........................ 60

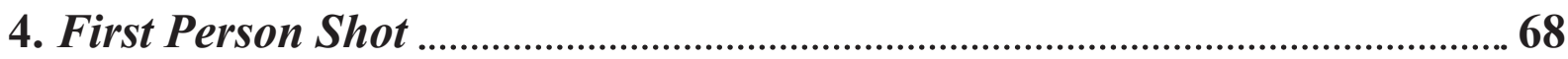

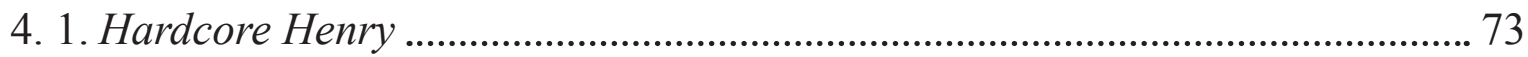

4. 2. Câmera intradiegética ..................................................................................... 77

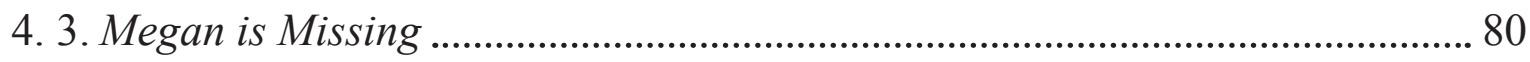

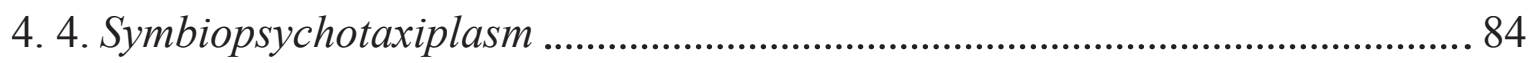

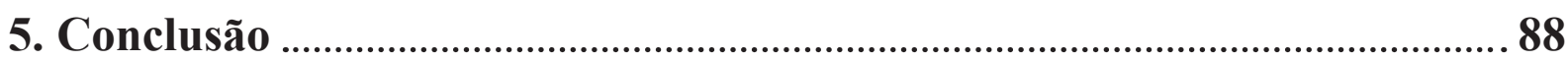

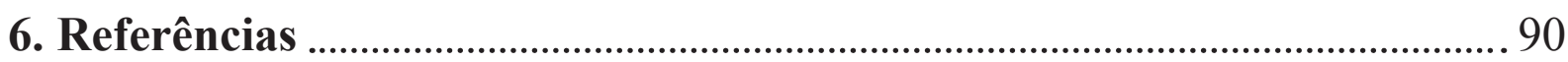

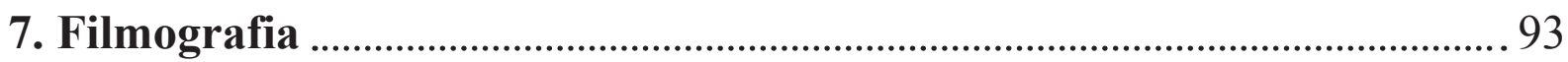




\section{Introdução}

O uso da câmera subjetiva vem desde os primórdios do cinema. O primeiro filme no qual este recurso de linguagem aparece, segundo Arlindo Machado ${ }^{1}$, data de 1900: As seen through a telescope, de George Albert Smith. Neste filme, o ponto de vista (POV, em inglês, PPV ou plano-ponto-de-vista, em português) subjetivo aparece marcado por uma íris e sucede a imagem de alguém olhando algo com uma luneta. A câmera subjetiva exibe o olhar de um curioso que aponta sua luneta para um casal com uma bicicleta, o companheiro da moça amarra os sapatos dela, e ao levantar um pouco a saia dela, deixa ver parcialmente sua perna. A moldura circular preta que circunscreve a imagem cinematográfica simula o interior do tubo da luneta, uma câmara escura cilíndrica, com suas lentes que permitem a aproximação do detalhe, a parte, o fetiche, mas também a distância e o anonimato. Um olhar voyeur, que desde o início do audiovisual associa a utilização de instrumentos ópticos da modernidade visual à satisfação de uma pulsão escópica. Marcas, máscaras, limitam a imagem, representando dispositivos ópticos como binóculos, lunetas, buracos de fechadura, denotando alguém que espia através deles, limitam o campo de visão com um enquadramento que se faz sentir enquanto materialidade.

Desde já a câmera subjetiva é determinada em sua própria matéria imagética, como também já é designada como visão de alguém pelo encadeamento narrativo das imagens: porque alguém olha por uma luneta que é possível ver, na imagem, o olhar do sujeito que vê, o personagem do filme. Curiosamente, como espectador posso ver também, uma vez que tudo parece bem arranjado para que eu justamente veja tudo, desde que me seja mostrado. A relação entre o ponto de vista ocular e o todo se codifica no filme pela reciprocidade do campo-contracampo: mostra-se objetivamente quem vê, mostra-se subjetivamente o que ele vê. Diferentes instâncias então concorrem a participar deste olhar, eu-espectador, ele-personagem, e o narrador-imagista que exibe as imagens em determinada ordem para caracterizá-lo como um olhar atribuído ao personagem, configurado por esta coincidência de pessoas diferentes que compartilham um mesmo eixo de olhar.

1 MACHADO, Arlindo. Pré-cinemas e pós-cinemas. Campinas: Papirus, 2007, p. 125. 


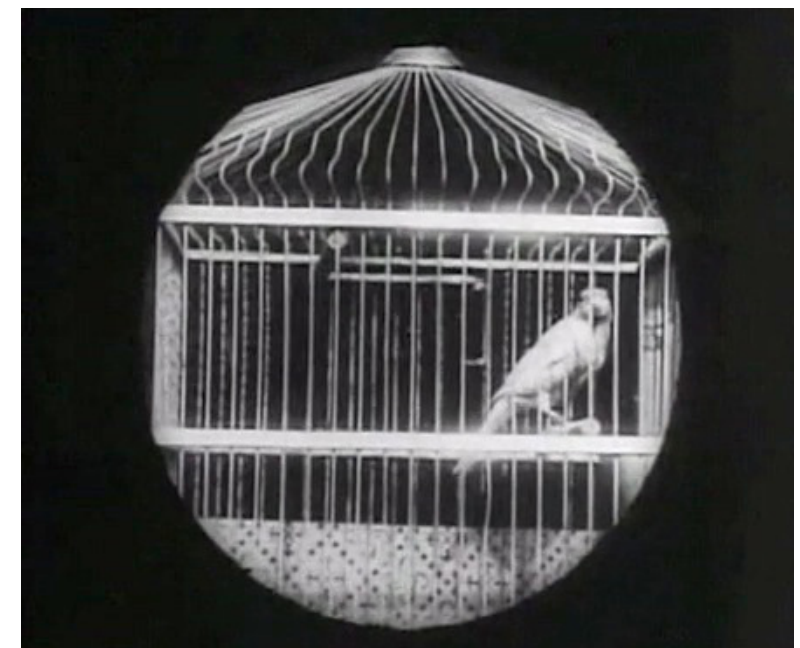

Grandma's Reading Glass, 1900

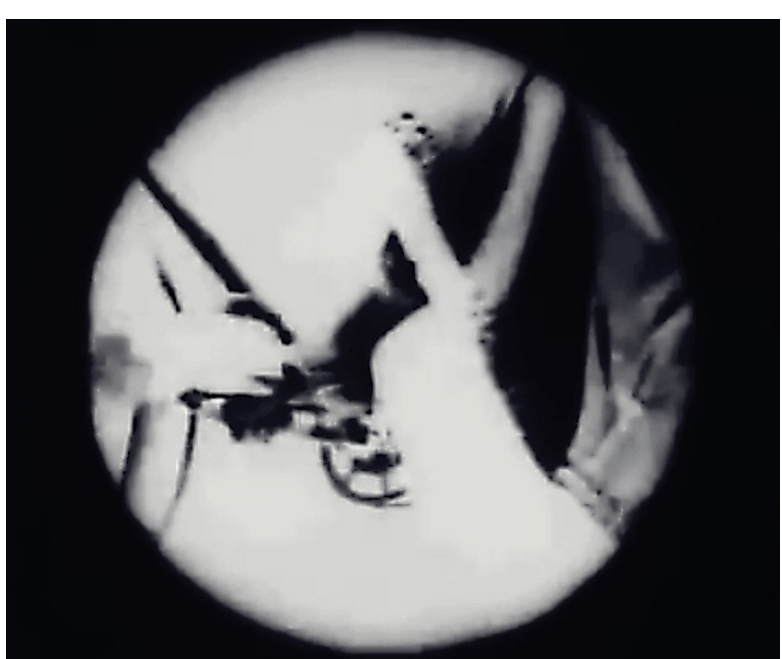

As Seen Through a Telescope, 1900

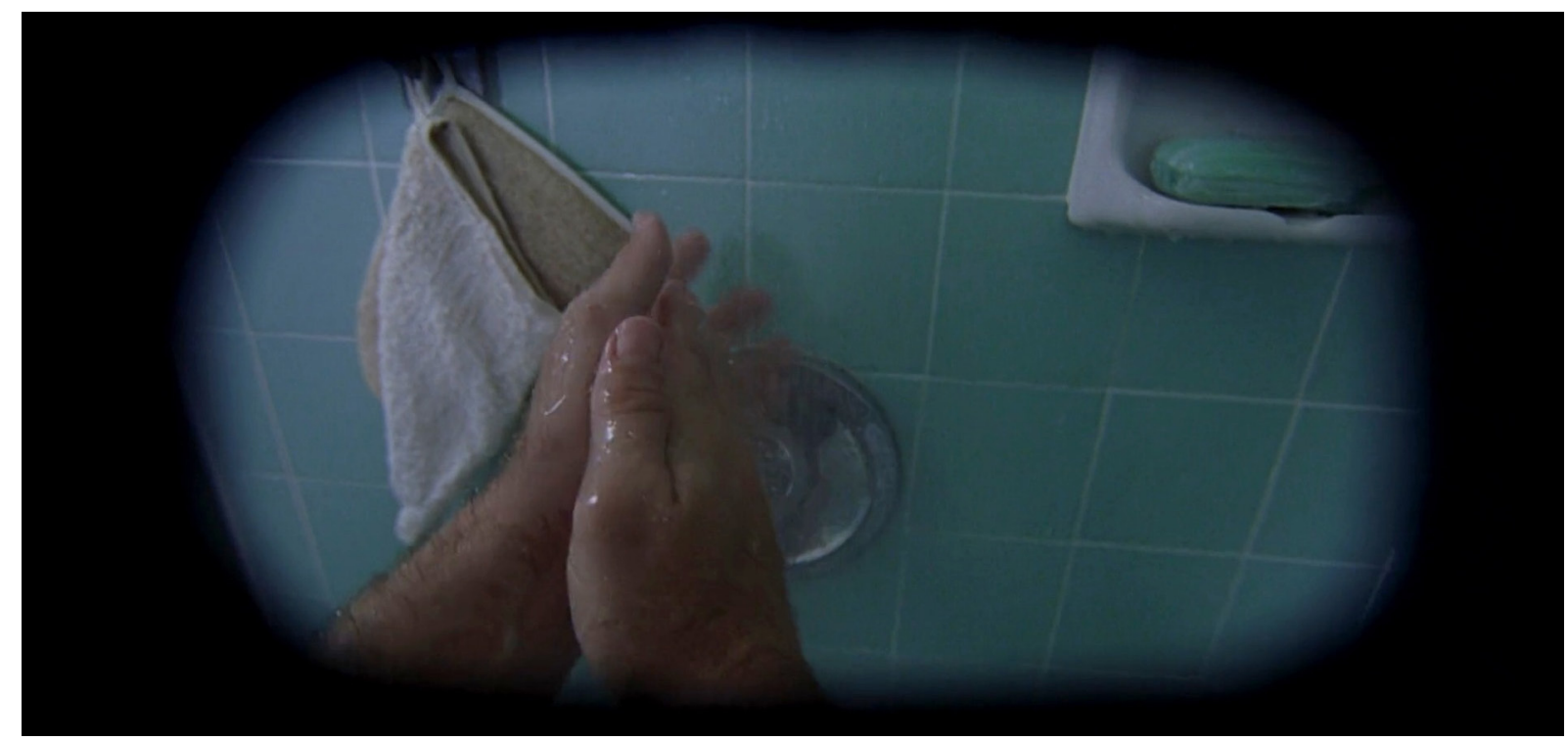

Quero ser John Malkovich, 1999

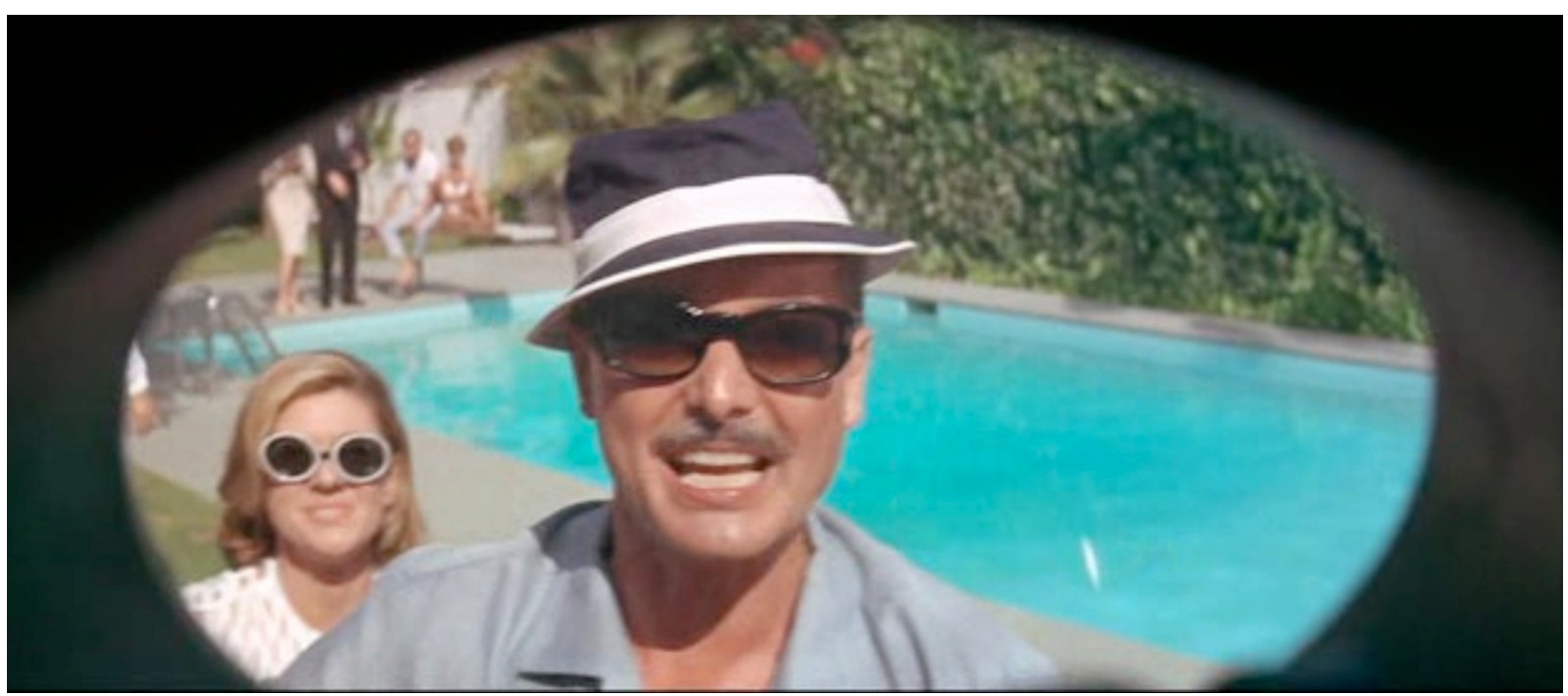

A Primeira Noite de um Homem, 1967.

Figuras 1 a 4. Máscaras na imagem do POV subjetivo. 
O olhar intradiegético entre personagens implica um olhar da câmera e um olhar do espectador, no qual o olhar da personagem para a câmera (para o espectador, por contiguidade), na convenção narrativa clássica foi algo a ser evitado. Quando coincidiam os olhares do personagem e da câmera/espectador, denominava-se plano subjetivo, câmera subjetiva: o olhar do personagem, a que o olhar do espectador se integra em maior ou menor grau. Este olhar é simetricamente oposto ao olhar do personagem à câmera. Como vetores de mesma direção e sentidos opostos, para dentro e para fora da diegese fílmica, estes olhares atuantes no eixo de profundidade questionam e mesmo denunciam a ilusão de transparência do cinema narrativo dominante. Por ser o olhar dirigido à câmera interdito no modo de representação clássico (porque destruiria a crença do espectador na verdade do mundo representado) tornava tão perturbadora a interpelação do olhar direto à câmera, como faz a personagem de Harriet Andersson em Monika e o desejo, de Ingmar Bergman.

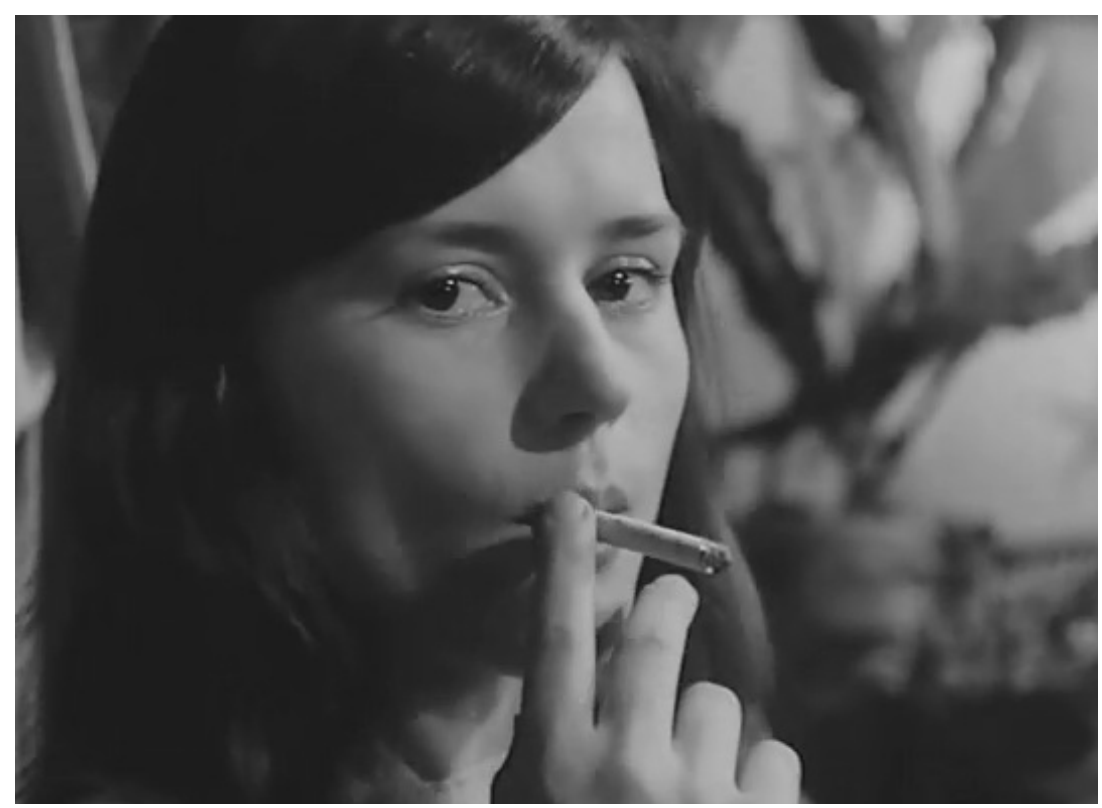

Figura 5. Harriet Andersson fita longamente a câmera em Monika e o desejo, de Ingmar Bergman.

A câmera subjetiva, portanto, faz coincidir no mesmo eixo que os atravessa, os olhares do personagem e do espectador em um olhar remissivo, endereçado, coincidente, um olhar em primeira pessoa. Estabelece entre filme e espectador um modo de imersão, pela percepção simultânea do corpo-câmera profílmico e da consciência-câmera do espectador. A câmera subjetiva sistemática, orientando a totalidade ou uma parcela majoritária da duração do filme, estabelece coordenadas de inserção perceptiva e cognitiva para seu espectador, para que este usufrua dos 
dados materiais e lógicos que a organização do filme dispõe, para que possa construir um discurso e, ao mesmo tempo, interceder em uma experiência.

Nos anos 30, em O Médico e o Monstro, baseado na obra de Stevenson, Rouben Mamoulian cria uma sequência admirável em câmera subjetiva na abertura do filme. A Dama do Lago e O Prisioneiro do Passado, ambos de 1947, ousam sistematizar o uso da câmera subjetiva, inserindo o espectador em uma experiência sensorial e perceptiva que não cede à ubiquidade de múltiplos pontos de vista, mas associa à câmera um ponto de vista antropomórfico duradouro. A câmera subjetiva sensório-motora se inscreve em um espaço e em um tempo vividos, e padece também das limitações advindas de sua ancoragem na situação, como restrições de mobilidade ou dificuldades de transpor limites físicos e temporais. Visto que o ponto de vista subjetivo é necessariamente seletivo e restritivo por sua própria definição, acarreta um zoneamento da diegese diferente da ubiquidade proporcionada pelos múltiplos pontos de vista assumidos pela câmera. Essa ancoragem dá à movimentação da câmera e sua disposição no espaço, bem como à duração da tomada, uma vinculação às mesmas coordenadas de tempo e espaço que incidem sobre o sujeito que sustenta o ponto de vista. Por isso mesmo, do ponto de vista narrativo, é quase que condenado à mobilidade para compensar sua ancoragem: para além de uma mise-en-scéne, tratar-se-ia de uma mise-en-caméra onde o mundo preexistiria à filmagem.

Nos últimos vinte anos há uma onda crescente de filmes que utilizam a câmera subjetiva, a câmera intradiegética e o first person shot como recurso estrutural audiovisual narrativo. O termo câmera subjetiva, já consagrado no vocabulário do cinema, é uma denominação comum. Mas é genérico e engloba diversas configurações do sensível que, se por um lado implicam um sujeito que olha aquela imagem, um dono daquele olhar, por outro lado mobilizam redes de câmeras, de monitores, dispositivos compartilhados, material coletado, todo um domínio da técnica que transfigura este sujeito, de modo que o termo genérico câmera subjetiva é aplicável, mas é necessário distinguir implicações diferentes de subjetividade. O sujeito passa a ser configurado pelo dispositivo, por seu sistema referencial e enunciativo, um sujeito-da-câmera.

A câmera subjetiva se desdobra em novas figuras de subjetividade contemporâneas, em função de novos usos deste recurso em franca ascensão no audiovisual contemporâneo, como a câmera intradiegética e outras configurações do first person shot. É importante salientar que a primeira pessoa, além do caráter designativo pertinente ao ato de enunciação, operado pela fala, pela montagem, etc. possui uma corporeidade, e possuir um corpo acarreta uma centralidade referencial, à qual convergem as imagens do mundo, tornando-o um body sensor, transiente pela diegese fílmica. A câmera se faz notar adquirindo um corpo, visível parcialmente ou invisível, parte de seu operador, parte da personagem que a encarna, parte sensório-motora 
de um espectador embutido, que transparece como corpo-câmera na imagem produzida, como indício, rastro de movimento, fantasma, ponto de vista, ancoragem e reciprocidade perceptiva intradiegética.

Se esta figura era devedora de uma concepção antropomórfica, que implicava equivalência a um olhar humano, hoje é possível referirmo-nos a um olhar sem olho, limite onde uma máquina de visão pode dispensar o olhar humano para se exercer, como é o caso de câmeras de vigilância, produtoras de imagens que provavelmente nunca serão vistas por ninguém. Há a invisibilidade de uma multiplicação e onipresença de dispositivos audiovisuais miniaturizados que podem ser instalados em lugares cada vez mais inusitados. Por outro lado, há na presença e na visibilidade das câmeras intradiegéticas um papel testemunhal: de registradora inserida no cerne do acontecimento, também exerce uma função catalisadora e mesmo desencadeadora do acontecimento fílmico.

O first person shot, que será abordado adiante, é uma condição contemporânea tributária de diferentes técnicas, principalmente da imagem sintética digital, mas encontra respaldo também em uma valorização social e política do testemunho subjetivo e do apelo do vivido para o atestado de veracidade do relato em primeira pessoa. Contribui também para afrouxamento sensório-motor dos encadeamentos narrativos em prol das qualidades afetivas das situações e do poder de atração por vínculos sensoriais, por associações diretas do pensamento, mais que pela via da representação. 


\section{Câmera}

"De todos os instrumentos feitos pelo homem, nenhum se parece mais com uma parte de seu corpo do que a câmera com o olho. E não é somente pela aparência. Uma câmera não é mais cópia do olho do que uma asa de pássaro o é de uma asa de inseto. Cada um deles é um produto de uma evolução independente; e se isso aproxima o olho e a câmera, não é porque um imitou o outro, mas porque ambos tiveram de enfrentar os mesmos problemas, e frequentemente do mesmo modo. Este é o tipo de fenômeno que os biólogos chamam de evolução convergente, ainda que em um caso a evolução seja orgânica, e no outro, tecnológica."

George Wald, Nobel de Fisiologia em 1967

"Se o olho se assemelha até certo ponto a uma máquina fotográfica, se a retina é comparável a uma espécie de chapa sensivel, o essencial da percepção visual realiza-se depois."

Jacques Aumont, A Imagem, p.16 


\section{1. Câmera-olho, olho da câmera}

A aproximação entre a câmera e o olho transcende a óptica e configura uma experiência tecnestésica, como quer Edmond Couchot. A técnica e a sensação coalescem em uma percepção mediada. Entre o automatismo técnico e a subjetividade, repousa a questão do voluntário e do singular, atributos da subjetividade, mas também a questão da técnica enquanto uma modelagem da percepção, que cria um sujeito modelado, coletivo, partilhado, e se ainda é possível atribuir-lhe singularidade, deve-se ao poder de reverter a técnica a seus desígnios. Para Couchot, esses dois componentes do sujeito convivem dinamicamente:

Um sujeito-NÓS modelado pela experiência tecnestésica e um sujeito-EU que resgataria a expressão de uma subjetividade irredutível a todos os mecanismos técnicos e a todo habitus perceptivo, singular e móvel, própria ao operador, à sua história individual, a seu imaginário².

A técnica (e principalmente o digital, ou nos termos de Couchot, o numérico), por sua evolução tecnológica e teleológica, ameaça automatizar a própria criação artística, autonomizando os processos com o risco de levá-los ao tecnicismo. Para o artista torna-se necessária a mobilização de sua capacidade inventiva, da vontade de não se submeter ao automatismo técnico e tomar as rédeas de sua criação. Desde o Quattrocento tornou-se necessário para a arte "contrabalançar a visão despersonalizada imposta pela automatização da imagem, insistindo na singularidade e na individualidade do criador, sobre sua imaginação criadora. Era necessário que à máquina se opusesse o que para ele, era menos maquínico: a subjetividade"3.

O pintor do Renascimento já lidava com esta polarização, e de uma série de dispositivos imagéticos resultaram modos de figuração que mantiveram a tensão entre automatização técnica e a subjetividade posteriormente:

Não há ruptura essencial na relação do sujeito, da imagem e do objeto (esta fração do mundo ou do real a representar) entre o sistema teorizado por Alberti e a fotografia. Há um prolongamento e reforço, um reforço que aproveita toda a potência dos procedimentos de automatização da imagem - de sua produção e reprodução - desenvolvidas entre o fim do séc XVIII e a primeira metade do séc XIX e já em semente desde as invenções do Quattrocento ${ }^{4}$.

2 COUCHOT, E. A tecnologia na arte: da fotografia à realidade virtual. Porto Alegre: Editora da UFRGS, 2003, p. 17.

3 Ibid, p. 27

4 Ibid, p.26 
O dispositivo intersector, com o qual o pintor podia medir as proporções relativas da projeção em tela do objeto, é uma máquina simples que faz corpo com o pintor, uma técnica compartilhada, mas que não é suficiente para a obtenção automática da imagem. A operação figurativa implica o sujeito aparelhado, impessoal e anônimo, compartilhado enquanto técnica com os outros pintores. A subjetividade singular do pintor sobressairia sobre a sua técnica, para Alberti, não através da técnica óptica, mas pela configuração narrativa de uma historia.

A tradição epistemológica moderna, desde Descartes, quis supor sempre um sujeito por detrás do ato perceptivo. A perspectiva artificial, desenvolvida desde o Renascimento, e contemporânea desta epistemologia, dispõe o observador diante da bidimensionalidade e simula a terceira dimensão espacial inexistente na superfície da tela: um eixo de profundidade que representa um mundo proporcional ao observador, e que o posiciona ao longo dessa direção perspectiva, essa linha de visão, fazendo do olho do observador um ponto matemático virtual dedutível da projeção das linhas perspectivas. Segundo este modelo perspectivo monocular denominado perspectiva artificial é possível, através da imagem vista reconstituir o seu ponto de vista, segundo seu código exclusivamente espacial. $\mathrm{O}$ olho virtual que ocupa este ponto de vista, seja vivo ou seja máquina, lhe corresponde ponto por ponto, espacial e perspectivamente. A perspectiva instaura um centro organizador bem definido que se confunde com um olho, mas um olho sem corpo.

$\mathrm{Na}$ busca pela definição da imagem, em seus parâmetros de luminosidade, proporção e espacialidade perspectiva ${ }^{5}$ em função da representação verossímil, desde o Renascimento vem sendo utilizados espelhos e lentes, entre outros instrumentos ópticos e de medição, para desenvolver as técnicas da perspectiva e do realismo pictórico, fotográfico, pré e pós-cinematográfico. A produção de imagens é um poder de re-produzir o mundo. A perspectiva linear teve que impor correções às anomalias perspectivas para estabelecer o código visual da visão especular renascentista. A construção de lentes e câmeras implica o fundamento da perspectiva, e a placa sensível, a película fotográfica e o sensor cumprem o papel de superfície bidimensional sobre a qual a tridimensionalidade real se projeta.

Câmeras escuras, lentes, fontes luminosas, a óptica define o olho como ponto, centro sem corpo, função de uma câmera objetiva necessariamente transparente, puro veículo ou passagem desmaterializada que dá acesso a uma realidade preexistente à sua presença. Um olho "sepa-

5 HOCKNEY, D. David Hockney e o Conhecimento Secreto. Documentário. David Hockney estima que por volta de 1420 o caráter realista da pintura foi se impondo nas artes visuais graças à utilização de dispositivos ópticos. A camera lucida permitia ao desenhista uma acuidade fotográfica ao sobrepor à superfície do suporte a imagem do modelo, juntamente à observação presencial tradicional, que auxiliava na demarcação dos traços, contornos, proporções e distâncias, bem como da volumetria e luminosidade. A pesquisa de Hockney desvenda o papel fundamental de dispositivos ópticos simples, como espelhos côncavos e lentes convergentes, na representação pictórica e na busca do realismo visual. 
rado e externo", uma objetiva, vidro cristal líquido e certo, tênue, quase evanescente, película formada por tensão superficial da membrana, meio, medium.

O aparelhos de captura audiovisual (tanto a câmera de filmagem quanto o gravador de áudio), responsáveis pela captura de imagens e sons simultâneos, são resultado da evolução e da convergência de processos tecnológicos, amparados pela instituição social do cinema, tanto o dominante quanto a constelação de formas alternativas adjacentes. A representação visual, fruto de convenções e construída através da verossimilhança, atribui aos dispositivos ópticos, aos processamentos e à imagem valores advindos de concepções determinadas historicamente . $^{6}$

Se a perspectiva moderna, linear, aparenta uma construção subjetiva simbólica e formal, sua construção não corresponde de fato em nada à experiência perceptiva do mundo, mas sempre uma aproximação, um código, um sistema diferente da fenomenologia da percepção natural.

\section{1. 2. Antropomorfismo}

Para que os aparelhos de captura de imagem e som funcionem como olhos e ouvidos do personagem em um regime de vinculação, a que se pode chamar de orgânico, de clássico ou mesmo de naturalista, diversos códigos imagéticos e sonoros foram criados de modo a naturalizar o modus operandi dos gravadores em um simulacro de percepção natural. O aparelho se oculta (ou se torna transparente: imperceptível ao máximo possível) para que o resultado de sua operação simule a percepção imediata do personagem. Essa codificação é um trabalho de linguagem, de técnica, de recursos tecnológicos que a possibilitaram, ao longo da história em seus múltiplos dispositivos?. "Há dispositivo desde que a relação entre elementos heterogêneos

6 CRARY, J. Técnicas do Observador. Rio de Janeiro: Contraponto, 2012, passim. Jonathan Crary analisa o modelo da camara oscura na constituição do sujeito observador e seu deslocamento no séc. XIX por conta de novas técnicas imagéticas. A mudança de paradigma descrita por Crary em Técnicas do Observador, tinha na camera oscura a base monocular de produção de imagens, que correspondia à epistemologia do sujeito defendida por Descartes, e passou a um paradigma subjetivo, onde a percepção da imagem é afetada por um sujeito que a limita e condiciona, e que deu origem a novas pesquisas e novos dispositivos ópticos, tais como as afterimages e o estereoscópio. Crary reflete sobre como dispositivos ópticos atuam no corpo e na subjetividade, e afetam os fenômenos perceptivos de uma época.

7 AGAMBEN, G. O que é o contemporâneo e outros ensaios. Chapecó: Argos, 2009. Giorgio Agamben ressalta a importância que o dispositivo assume no trabalho de Michel Foucault e resume suas características: "a. É um conjunto heterogêneo, linguístico e não-linguístico, que inclui virtualmente qualquer coisa no mesmo título: discursos, instituições, edifícios, leis, medidas de polícia, proposições filosóficas, etc. O dispositivo em si mesmo é a rede que se estabelece entre esses elementos. b. O dispositivo tem sempre uma função estratégica concreta e se inscreve sempre numa relação de poder. c. Como tal, resulta do cruzamento de relações de poder e relações de poder" (p. 29). Para Agamben, o dispositivo comporta em Foucault significados jurídicos, tecnológicos e militares. Agambem ressalta as noções de "positividade" e "dispositio", da qual deriva o termo dispositivo. Dispositio é a tradução latina para a palavra grega oikonomia, que literalmente quer dizer "gestão da casa", e foi aplicada pela teologia cristã ao papel da Santíssima Trindade. Assim, o termo dispositivo recobriria "aquilo em que e por meio do qual se realiza, na cisão entre ação e ser, uma pura atividade de governo sem nenhum fundamento no ser"(p. 38) e implicam processos de subjetivação e produzem sujeitos, que, como define Agamben, são resultados da relação e, por assim dizer, do corpo a corpo entre os viventes e os dispositivos” (p. 41) 
(enunciativos, arquitetônicos, tecnológicos, institucionais etc.) concorram para produzir no corpo social um certo efeito de subjetivação" ". Essa naturalização do efeito subjetivo, simulador da percepção natural humana, é um antropomorfismo.

Antropomorfismo é a atribuição de características humanas ou pessoais a um objeto não humano. Alguns aspectos referentes a uma câmera como ângulo de visão, posição, movimentação, direção e velocidade de deslocamento, sua "atenção" aos objetos, podem simular as percepções e o corpo de um ser humano. Muitas qualidades de uma imagem-câmera referem-se ao modo humano de ver, mover-se, ou mesmo sentir e pensar. O grau de antropomorfismo está conectado ao envolvimento sensório-motor e sentimental com o mundo e com os personagens deste mundo. Se traços humanos são atribuídos a uma câmera, revelando de algum modo ou em algum grau a experiência subjetiva da personagem, um ser humano, diremos que se trata de uma câmera subjetiva antropomórfica. Se for um animal, um inseto, por exemplo, cuja visão é simulada por uma câmera/dispositivo, (e chamá-la de zoomórfica nada resolve, muito menos antropomórfica), deve haver no deslocamento deste dispositivo imagético uma mobilidade que simule um vôo de inseto, pode haver na textura imagética signos que modifiquem a imagem de modo a simular a visão dele, mas de qualquer modo a simulação leva em conta o tamanho, a proporção, a qualidade, a possibilidade e a velocidade do movimento e do deslocamento do sujeito, características de sua percepção visual e de sua propriocepção.

\section{1. 3. Sujeito-da-câmera}

Em A imagem-câmera, Fernão Ramos denomina sujeito-da-câmera a interação fenomenológica da presença da câmera e de seu operador na cirscunstância da tomada da imagem. O sujeito-da-câmera indica uma ancoragem no mundo do dispositivo, que refletido em seu suporte sensível, remete esta representação a um fruidor, um espectador. É primordial o caráter indexical de presença no mundo deste aparato, presença que é delegada em segunda mão ao espectador da imagem-câmera. "O sujeito-da-câmera existe sempre através do sujeito concreto espectador; é, portanto, determinado em sua característica de se remeter à situação de fruição, de poder existir para o espectador"’. O sujeito-da-câmera, índice de subjetividade produzido pelo filme, propõe-se a inscrever a presença do sujeito no corpo da imagem.

8 PARENTE, A. in PENAFRIA, M. MARTINS, I.M. Estéticas do Digital. Covilhã: Livros LABCOM, 2007, p. 9-10.

9 RAMOS, F. A imagem-câmera. Campinas: Papirus, 2012, p. 91. 
A ancoragem perceptiva que a câmera subjetiva implica na diegese dificulta o fluxo fragmentado das imagens, a menos que o sujeito-da-câmera se ponha em movimento vertiginoso. $\mathrm{O}$ fluxo das imagens está diretamente ligado à ancoragem perceptiva deste sujeito na diegese, em uma câmera subjetiva, que recorre frequentemente ao plano-sequência, mas também recorre à sutura: os cortes existem e devem ser costurados também pelo espectador, as elipses espaciais e temporais continuam a ser articuladas no desenvolvimento do personagem-câmera. Além disso, ao simular esta identificação com o ponto de vista naturalizado de um ser vivo, e requerer o embarque do espectador para consumá-lo, simultaneamente dificulta a identificação com o personagem através do qual se vê mas que não aparece propriamente em imagem, gerando uma identificação paradoxal.

A ausência deste personagem em imagem, salvo pontualmente e secundariamente, em reflexos e espelhos, constitui uma possibilidade de acoplamento personagem/sujeito/espectador, e o dispositivo personagem/sujeito seria algo a se dispor ou não, afim de que a identificação ocorra. Mas a ausência em imagem do sujeito-da-câmera (como ele poderia estar diante da câmera se ele está "imediatamente" atrás dela?) não deixa de gerar mal-estar para a identificação (como poderia me identificar completamente com alguém que não conheço?). Talvez este tenha sido o motivo de tanta desconsideração e desestímulo de seu emprego por parte da teoria e da crítica cinematográfica.

A câmera subjetiva envolve mais que unicamente a percepção visual. Como percepção de um sujeito-da-câmera, ela envolve uma rede de vínculos não somente espaciais, mas sonoros, hápticos, temporais; como entidade física de aparelho de captura envolve tecnologias e processos, procedimentos que facultam ou intervêm no seu trabalho de produção de imagens e em sua presença no ato de captação; como indicadora da pessoa que representa, possui o poder de identificar e referir, de designar e de autodesignar, por atos de fala de personagens ou narradores que a amparam, e por seus recursos materiais sensíveis.

\section{1. 4. Identificação}

Renato Luiz Pucci Jr. ressalta a importância do efeito de identificação promovido pela câmera subjetiva:

Cineastas e teóricos nunca menosprezaram os efeitos desse procedimento. Além do incremento de verossimilhança narrativa por meio da identificação espectador/personagem, destaca-se a sugestão de falsa neutralidade do narrador. Em outras palavras, quando a narração é entremeada por planos de câme- 
ra subjetiva, ao invés de apresentar apenas uma visão externa dos fatos narrados, ela é supostamente corroborada por exibir de forma direta a experiência de quem vive a cena ficcional. Para o cinema clássico, em que a credibilidade da narração é fundamental, a câmera subjetiva se torna um dos recursos mais importantes à disposição dos realizadores ${ }^{10}$.

Jean-Louis Baudry partiu da configuração da perspectiva para teorizar o dispositivo cinematográfico assentado no "aparelho de base". Baudry propôs em 1970 a ideia de que o dispositivo cinematográfico era responsável pela constituição do espectador como sujeito. O regime perspectivo definia um lugar pontual para o observador, onde o situava. Depois, as imagens em movimento definiam o "sujeito transcendental" que reunia numa unidade de consciência o fluxo fragmentado das imagens; e, finalmente, o dispositivo como um todo produzia a identificação do espectador com este sujeito observador transcendental, no qual o filme funcionaria com um espelho.

Uma outra teoria fundada na psicanálise se vale da falta ou ausência de um sujeito real para construir um sujeito transcendente e incorpóreo. A teoria da sutura quer preencher o espaço da visada com um sujeito, a quem o espectador corresponde. Herdeira da psicanálise freudiana e lacaniana, lhe interessa a noção de falta. No cinema subjetivo clássico, o plano é complementado com o contra-plano de um personagem, com quem então o espectador identifica-se como o sujeito da percepção. O campo/contracampo atribui um olhar a alguém, dentro da diegese, e este pertencimento é sempre designado pelos eixos de olhar e pela sucessão olhar/olhado. Para a teoria da sutura, é o sujeito que exerce o processo de leitura cinemático, mesmo que inconsciente disso durante a leitura. Identificação é a chave, o sujeito fílmico confunde-se com o sujeito filmado, o espectador identifica-se com um personagem, ou mesmo um ator do filme. Todo plano filmado evoca um campo ausente onde está um personagem imaginário criado, mas não o tempo todo, pelo espectador. Convencionou-se que o plano frontal, ao ocupar a posição de visão de um personagem, causa um estranhamento que denuncia a ilusão. O lugar de sujeito do discurso cinemático que o espectador deve ocupar só é possível a partir de uma ausência na imagem, que seria o correlato do campo do imaginário. O espectador posiciona-se fora de quadro, adotando o Ausente como o sujeito de uma visão que não é a sua, e a imagem como significante dessa ausência. Dessa forma, o espectador recupera a sua diferença.

Jean-Pierre Oudart, defensor da teoria da sutura, revela como em O Processo de Joana D’Arc, Bresson posiciona a câmera de modo que a ela corresponda um sujeito, o espectador, 
assegurando-lhe um espaço reservado na diegese. Aqui, a obliqüidade da câmera em relação ao eixo dos olhares indica o lugar próprio do espectador. Mas de tal forma que este não é um sujeito fictício, mas um sujeito simbólico, que trava uma relação deliberada com o discurso fílmico: seu lugar está reservado e designado pela mise-en-scéne como mais uma testemunha, tal qual os outros personagens do julgamento de Joana. Bresson, com este procedimento, desnuda o que era apenas imaginário, cria um lugar simbólico que explicita a participação efetiva do espectador. A obliqüidade do ângulo atesta um deslocamento do espectador em relação à transparência do discurso. Desse modo, Bresson rompe com o ilusionismo do discurso clássico. Expor o mecanismo de sutura é expor aquilo que deveria ter permanecido oculto no processo de significação. Porque o discurso produziu-se a nível ficcional, gerando uma narrativa dividida ou dupla, o sujeito imaginário do discurso é subvertido. A dificuldade da teoria da sutura com a câmera subjetiva é justamente essa: a evidência da participação do espectador no processo de significação. Não se pode chamar de subjetivo esse que Bresson faculta ao espectador: a imagem não designa um personagem entre o espectador e o filme. Nada indica o personagem, não há interpelação direta, não se olha à câmera, nada de travellings. Como não há o personagem-câmera, não há reciprocidade perceptiva intradiegética entre ele e os outros personagens. Mas há uma via aberta pelo ponto de vista ocular da câmera que conecta, no eixo da profundidade, o espectador e a diegese do filme pela função testemunhal, um antropomorfismo que designa um lugar pontual a ser ocupado, e o que ver a ser ocupá-lo se dá em um âmbito participativo articulado como dispositivo: uma estratégia para significar o olhar pretensamente isento do espectador.

Este sujeito transcendental e incorpóreo não poderia ser interpelado diretamente por um personagem, pois não pertence a diegese, mas está fora dela, e por estar nessa condição extradiegética transcendental é que pode suturar as lacunas de um fluxo fragmentado de imagens.

\section{1. 5. Ponto de vista e ponto de escuta}

O ponto de vista e o de escuta, na narrativa audiovisual, referem-se principalmente a duas acepções: uma acepção espacial e uma acepção subjetiva.

A acepção espacial diz respeito ao lugar de onde a cena é mostrada, de onde a câmera foi posicionada, e de onde o espectador, consequentemente, vê e ouve.

A acepção subjetiva leva em conta estas mesmas coordenadas, com o acréscimo de que elas pertencem a um personagem. Então, há um compartilhamento do ponto de vista do personagem e do espectador. Para que o espectador depreenda que o que ele vê ou ouve corresponde 
ao mesmo que o personagem percebe, é necessária uma designação contextual, simultânea ou sucessiva. Pode ser designada pela montagem, quando sucede-se a um plano de um rosto olhando para um ponto qualquer que não a câmera, um outro plano de imagem; pode ser que esta segunda imagem seja o que o personagem da primeira imagem via. Pode ser designada na própria imagem, prescindindo da articulação semântica da montagem, como quando algo é visto com uma moldura de binóculo, por exemplo. Neste caso, a própria imagem é dotada de uma segunda camada de observação, que pressupõe o ato de um observador diegético.

Em relação ao ponto de escuta, conceito derivado do ponto de vista, devido à natureza da percepção sonora, que não admite uma localização tão precisa, e da natureza omnidirecional do som, torna-se mais difícil falar de uma posição exata no espaço, não um ponto, mas antes um lugar ou uma área de escuta.

E no caso de um ponto de escuta subjetivo, geralmente este é condicionado pelo ponto de vista imagético, mais bem determinado espacialmente. Quando, por exemplo, ouve-se sons de fraco alcance, indícios de proximidade da fonte sonora; ou no caso de uma conversa telefônica, onde a materialidade do som permite situar o ponto de escuta como o de quem recebe ou efetua a chamada; ou mesmo o caso da respiração em off, muito associada à câmera subjetiva; é possível estabelecer pontos de escuta com maior acuidade e associá-los a um personagem. Mas, como ressalta Michel Chion, "na condição, evidentemente, de que a imagem, a planificação visual e o desempenho do ator lhe confirmem as deduções que pode fazer a esse propósito"11.

11 CHION, M. A audiovisão. Lisboa: Texto \& Grafia, 2011, p.75. 


\section{2. Câmera subjetiva e antropomorfismo}

Quero aqui levantar a hipótese de que a câmera subjetiva, vinculada ao regime da representação, atendo-se às narrativas que simulam a percepção de um sujeito antropomórfico ancorado no mundo, é insuficiente para lidar com narrativas que valorizam a flutuação, a errância, a deriva, a permuta e o compartilhamento da subjetividade. Por meio de uma relação entre a câmera e o olho - entre o dispositivo e o ato de olhar - no que essa relação implica um sujeito mediado, abordarei a intersubjetividade múltipla e móvel, ao mesmo tempo fluida e incorporável, construída pelos filmes contemporâneos que se valem do olhar em primeira pessoa. A câmera subjetiva, no código clássico do cinema, como instrumento da focalização, ocularização e auricularização narrativas, é justificada por ou designada a um pertencimento, um ponto de onde parte um olhar (ou de uma escuta), de um sujeito. Enquanto este se dá direta e imediatamente pela imagem enquanto consequência da espessura de sua matéria visual e sonora, ao mesmo tempo que só pode ser referido pela organização e configuração narrativa. À figura da câmera subjetiva, por sua limitação relacionada à sua ancoragem e seu antropomorfismo, defrontar-se-ão adiante outras formas híbridas e mais ambíguas como a subjetiva indireta livre ou o first person shot.

\section{2. 1. A Dama do Lago}

Diversos filmes iniciam em câmera subjetiva introduzindo o espectador na experiência perceptiva da personagem, geralmente anômala ou extraordinária, tais como $O$ Médico e o Monstro (Dr Jekyll e Mr. Hyde, 1931) de Rouben Mamoulian; Prisioneiro do Passado (Dark Passage, 1947) de Delmer Daves; Enter the Void (2009) de Gaspar Noé, O Escafandro e a Borboleta (Le Scaphandre et le Papillon, 2008) de Julian Schnabel; Estranhos Prazeres (Strange Days, 1995) de Kathryn Bigelow, entre outros. Como afirma Edward Branigan, o ponto de vista subjetivo frequentemente mostra, mais do que a visão, a dificuldade em ver de um personagem, correspondendo a visões motivadas por estados alterados de consciência, por anteparos dispostos defronte ao rosto ou aos olhos do personagem, ou o meio no qual ele está inserido, como a visão submarina, por exemplo.

Uma das funções da câmera subjetiva é introduzir o espectador no filme. $\mathrm{O}$ cartaz de $A$ Dama do Lago (Lady in the Lake, Robert Montgomery) convidava o espectador a entrar no filme e solucionar o mistério do crime junto com o diretor-ator Robert Montgomery.

Esse convite cria um espectador-personagem, apostando na câmera subjetiva como dispositivo de imersão do espectador no filme. Este ponto de vista subjetivo é antropomórfico 


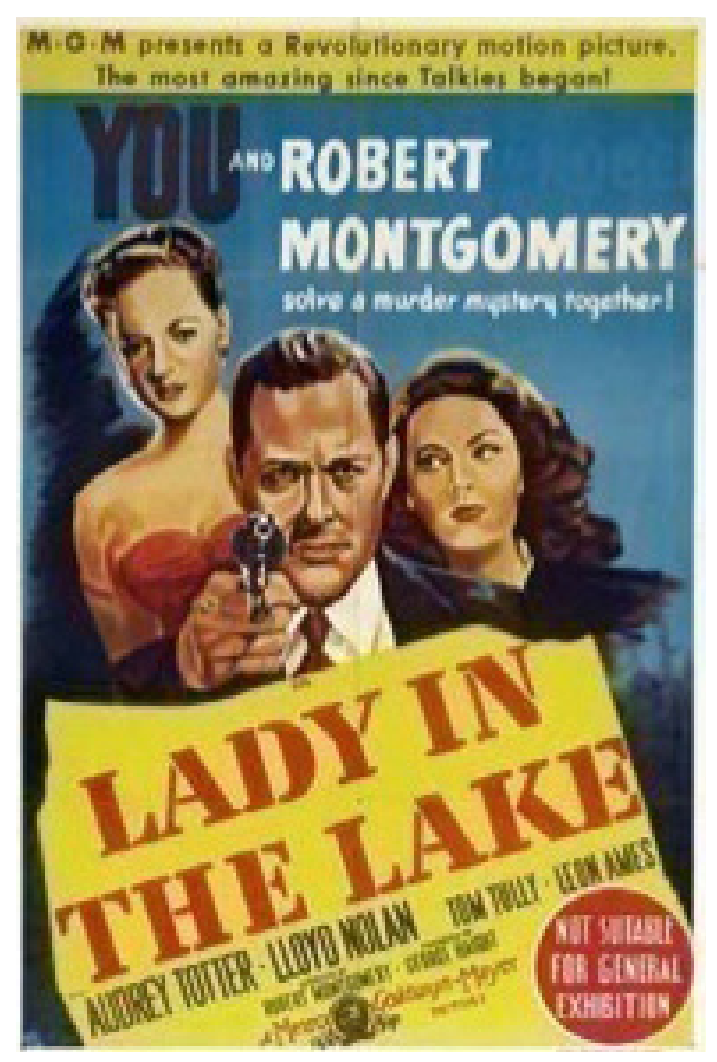

Figura 6. Cartaz do filme A Dama do Lago.

e traz diversos problemas para a eficiência desta identificação pretendida. Arlindo Machado aponta para a dificuldade de identificação do espectador com o personagem, uma vez que o personagem do detetive raramente é visto em cena, a não ser por reflexo em espelhos, ou nos interlúdios em que fala diretamente à câmera e ao espectador, criando assim um "enigma secundário e parasitário" que se refere ao rosto oculto de Marlowe. Machado cita a frase de Jean-Paul Simon que recobre o private eye do detetive com o private $I$ da câmera subjetiva. Além disso, os olhares diretos e interpeladores dos personagens à câmera tirariam o espectador da zona de invisibilidade a que estaria acostumado. Outras dificuldades incidem no corte entre os planos-sequência e na movimentação do personagem, desfavorecendo as elipses narrativas; ou então na ausência de multiplicidade de pontos de vista, o que conferiria ao relato pouco dinamismo; e ainda a sobrecarga dos diálogos, que para compensar as limitações anteriores, tornaria o filme excessivamente verborrágico ${ }^{12}$.

No filme Lady in the lake, a interpelação direta das personagens à câmera lembra ao espectador o seu estatuto de participação por meio de uma identificação com o sujeito da câmera, o protagonista desse olhar, envolvido num romance: 
É como se nos devêssemos identificar com um fantasma... Trata-se de uma dupla castração: de um lado, o sujeito e ele próprio elidido da cena e passa a ocupar nela o papel de uma falta; de outro, separado do mundo da mulher pelo muro da enunciação ${ }^{13}$.

Para Machado, a objetivação da personagem em imagem, seja refletido num espelho, como silhueta referencial de um ponto de vista ligeiramente deslocado de seu avatar, dão uma dimensão física mais aproximada deste ser do olhar, é a condição de identificação do espectador com a personagem.

A atualização dessa figura a que convida uma identificação, em Lady in the Lake torna-se mais difícil pelo que ele chama de "maniqueísmo da câmera subjetiva".

No entender de Machado, Lady in the Lake se depara com a dificuldade de corte dos planos-sequência, e com uma restrição à mobilidade da câmera por causa de sua coincidência com a personagem. Trata-se da incorporação de uma instância narradora ocularizada à presença antropomorfizada da personagem. A câmera equivaleria ao olhar da personagem em ato no espaço fílmico, que corresponde ao espaço de visão desse sujeito, a quem também são dirigidos múltiplos olhares. O deslocamento físico da personagem, em sua opinião, coíbe o uso de elipses narrativas e deslocamentos injustificáveis, direcionando a encenação para uma coincidência do tempo diegético com o tempo real. Além disso, os olhares diretos à câmera abalariam a invisibilidade do espectador e seu conforto de onipresença dentro da representação clássica.

Cercada por tais dificuldades, a câmera subjetiva se sustentaria apenas em relação a outros papéis enunciativos em um filme, articulada pelo campo/contracampo através da relação de vínculo olhar/olhado.

Machado insiste no enigma da ocultação da face do personagem pela câmera subjetiva. Enumera narrativas onde propositalmente sonega-se a identidade do narrador para efeitos de suspense ou surpresa, em reviravoltas de desfecho ou para questionar de maneira crítica o relato em primeira pessoa.

O filme de Delmer Daves Prisioneiro do Passado (Dark Passage, 1947), lançado no mesmo ano de A Dama do Lago, emprega a câmera subjetiva sistemática durante quase metade do filme. Aqui ela sonega propositalmente a face do personagem, até que ele faça uma operação plástica facial que o torne irreconhecível, pois é um fugitivo da prisão procurado pela polícia. Acusado de um crime que não cometeu, o personagem vivido por Humphrey Bogart se refugia 
na casa de uma amiga para se esconder e descobrir o autor verdadeiro do crime. Neste propósito, a ocultação da face do personagem assume a negação de um lugar social para o criminoso. A câmera subjetiva faculta, neste caso, a privação da identidade de um inocente em um ambiente que lhe é hostil, até que troque de rosto e de condição judicial.

É o olhar dos outros que julga incessantemente o personagem. E endossam a câmera subjetiva como instância passível de juízos não-verídicos, onde as identidades são incertas ou mesmo intercambiáveis.

Estão aqui presentes signos de subjetividade que investem o trabalho de cinematografia da câmera subjetiva, tais como as mãos que entram em quadro por seu lado inferior ou lateral;

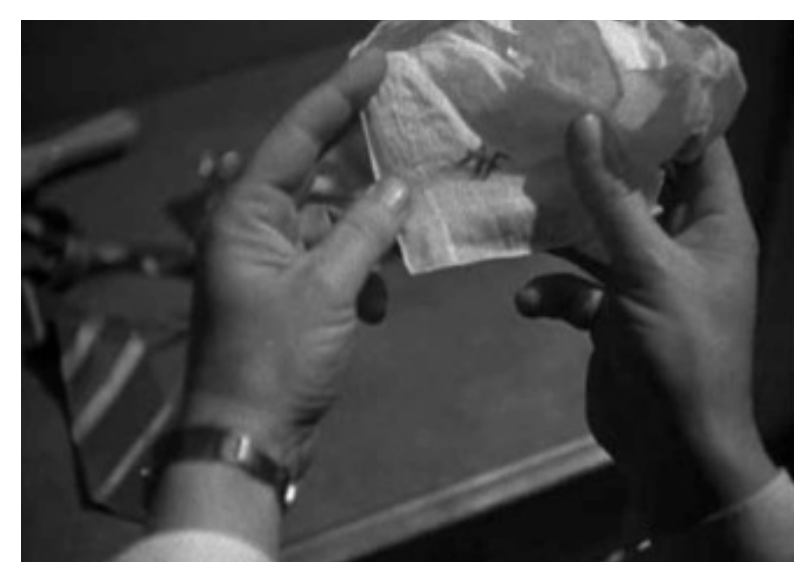

A Dama do Lago

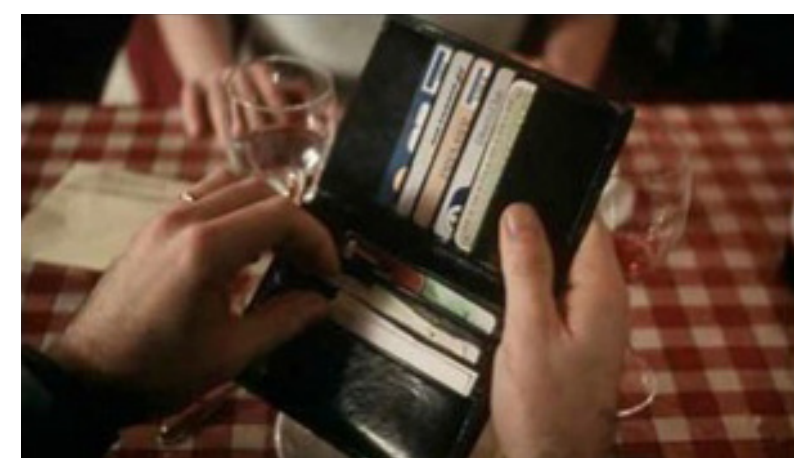

La Femme Défendue

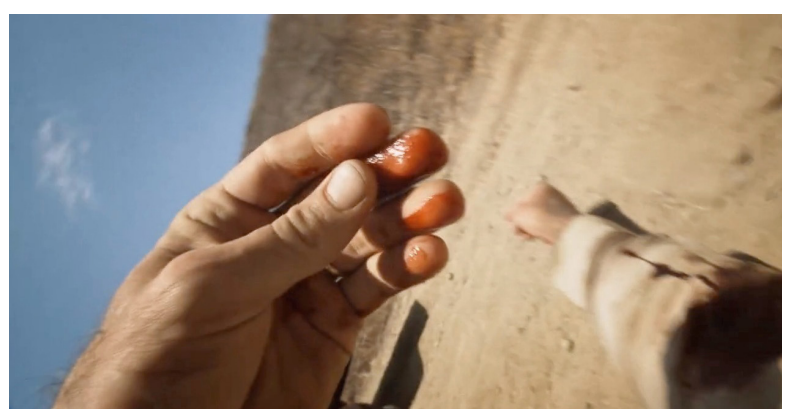

Random Stop

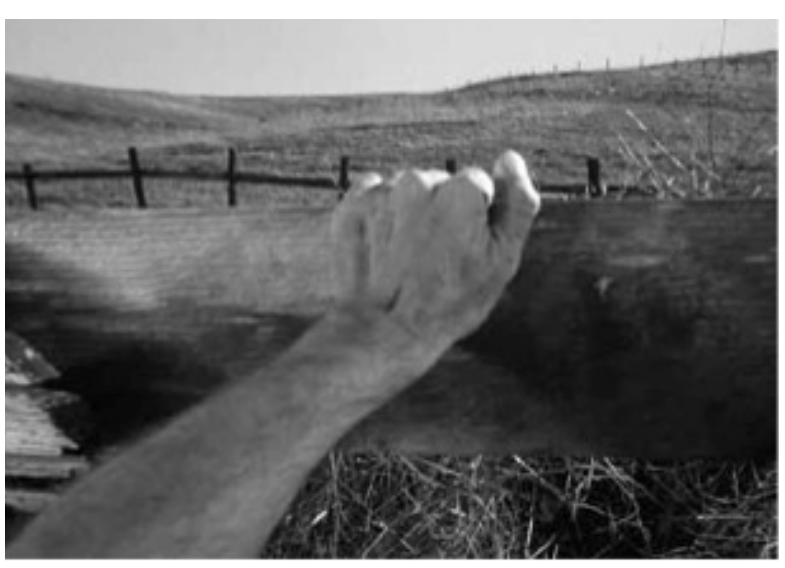

Prisioneiro do Passado

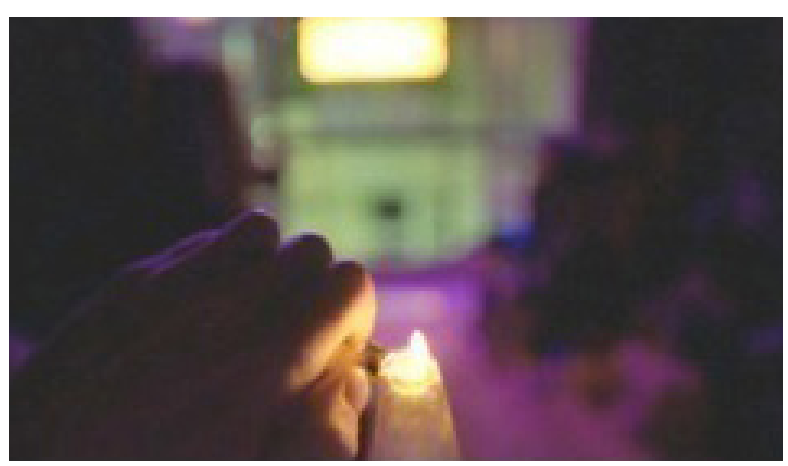

Enter The Void

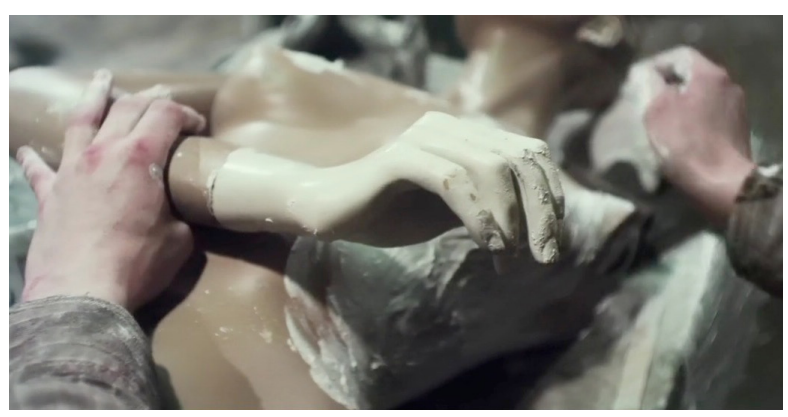

Maniac

Figuras 7 a 12. Mãos do personagem-câmera em filmes de câmera subjetiva. 
a movimentação do andar do personagem, que imprime ao movimento de câmera trepidação; a intencionalidade e a parcialidade dos movimentos e paragens da câmera, etc.

$\mathrm{Na}$ tomada em que o personagem rola dentro de um barril utilizado para se esconder e fugir na caçamba de um caminhão, o mundo gira freneticamente visto do interior do barril, como em uma lavadora de roupas, evidenciando o pathos da fuga e a reviravolta da busca da liberdade. É uma metáfora da íris do olho pelo qual espectador e personagem intercambiam o olhar.

Daves opera uma imersão da câmera no personagem ao mostrar o barril de onde as mãos saem para sacudí-lo afim de derrubá-lo do caminhão e iniciar a fuga. A câmera se torna subjetiva ao entrar no barril e mostrar a perspectiva de um renascimento a partir do ventre metálico onde o personagem esteve preso.

\section{2. 2. La femme défendue}

Comparando a configuração da câmera subjetiva em Eros, o Deus do Amor com A Dama do Lago, Renato Luiz Pucci Jr. atenta para o desprendimento de Walter Hugo Khouri na utilização do recurso. O autor sublinha no filme a intervenção de flashbacks; a despreocupação de mostrar em imagem o protagonista-câmera através de reflexos em espelhos; a discrição em mostrar partes de seu corpo, como mãos entrando em quadro ou manipulando objetos, tão frequentes em A Dama do Lago; a liberdade do uso de cortes e elipses espaciais; etc. Pucci Jr. provavelmente desconhecia o filme La Femme Défendue, que já apresentava características que procuravam romper com as restrições impostas à câmera subjetiva em A Dama do Lago, em seu controverso intuito de parecer verossímil.

Renato Pucci Jr. defende o uso da câmera subjetiva em Eros como "uma forma diferente de penetrar no universo interior de Marcelo e, como consequência, mostrar de que maneira o mundo se apresenta a seus olhos" ${ }^{14}$. Tratar-se-ia de reivindicar para o filme a "unidade irrevogável” que Percy Lubbock atribuía à narração autodiegética, por mais fragmentados que fossem os episódios narrados, referiam-se ao mesmo indivíduo. Faz sentido em relação ao filme Eros, pois a história da vida amorosa do protagonista Marcelo é bastante plural. Além disso, a rememoração empreendida por Marcelo possuiria um caráter "sinuoso de alguém que remói o passado sem a obrigação de seguir um plano preestabelecido" ${ }^{15}$. Assim, o tema de Eros é o próprio 
narrador, diferentemente de A Dama do Lago, onde não há nenhum interesse na caracterização pessoal de Marlowe. O expediente de A Dama do Lago refere-se à intenção testemunhal que pretende conferir ao espectador do filme.

Como em A Dama do Lago, cujo diretor é tambem o protagonista, Philippe Harel dirige e faz o protagonista-câmera em seu filme La Femme Défendue. Filmado completamente através da câmera subjetiva, conta um caso de amor entre François, casado e pai de família, e Muriel, uma moça de vinte e poucos anos interpretada por Isabelle Carré. A câmera subjetiva é assunto do filme tanto quanto sua história de adultério. O dispositivo da câmera subjetiva sobrepõe nestes filmes as instâncias do realizador, narrador, personagem, espectador e aparelho de captura.

Se o procedimento de A Dama do Lago teve que esperar meio século para ser novamente utilizado em outro filme, isto provavelmente decorre do tipo de crítica que considera o filme unicamente como exercício de estilo, e condenam a câmera subjetiva sistemática a ser vista como um recurso para ser usado em doses homeopáticas, nunca em um filme inteiro.

O filme, que de fato, apresenta uma movimentação pesada da câmera-personagem ou uma fixidez excessiva, escultórica, na qual os atores se distribuem imóveis no espaço anti-natural da mise-en-scéne, fixando seus olhares à câmera mesmo quando não falam nada. Um resultado forçado da busca do diretor para inscrever na imagem sinais, da presença de um sujeito-da-câmera: exagero e histrionismo das expressões dos personagens que fitam a câmera de maneira pouco natural e um tanto antiquada, remanescente do primeiro cinema.

Para que a encenação de La Femme Défendue não ficasse tão rígida e artificial, foi instalado um espelho semi-transparente defronte a lente da câmera inclinado a 45 graus, o que permitia
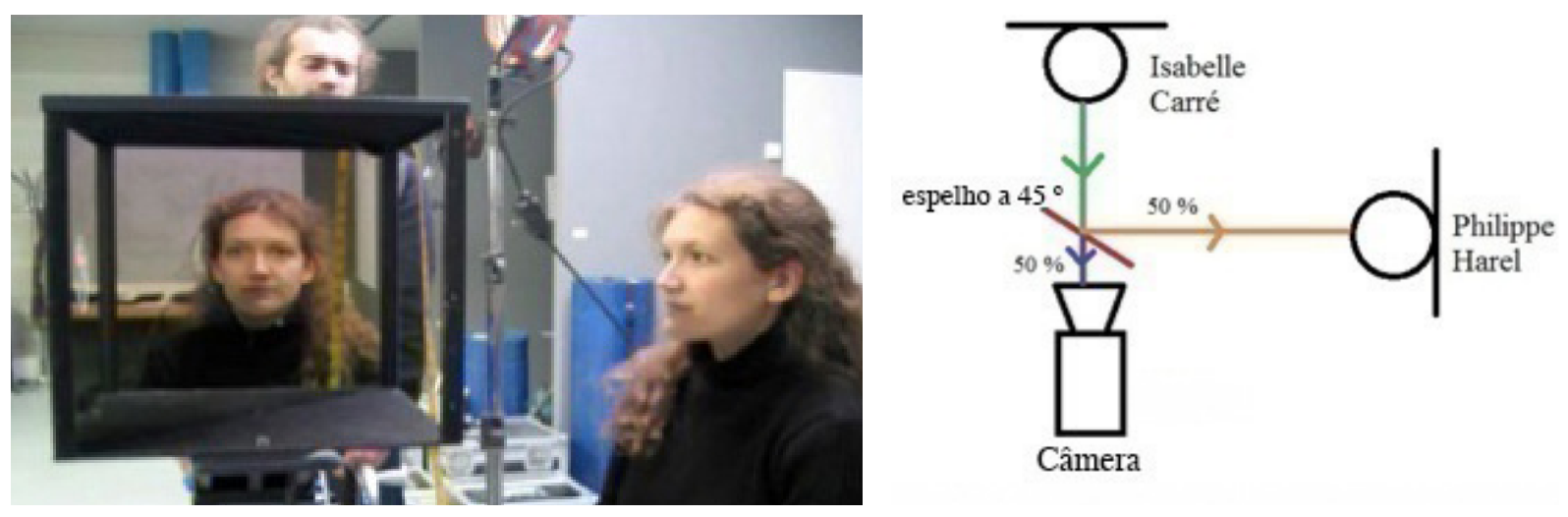

Figura 13. Esquema do uso de espelhos em La Femme Défendue. ${ }^{16}$

16 TITÉ, F. Technique et esthétique de la caméra subjective. Mémoire de fin d'études et de recherche. ENS Louis Lumière, 2011, p. 21. 
tanto a Philippe Harel quanto a Isabelle Carré olharem-se frontalmente (por reflexo) enquanto filmavam, o que deixava a contracena e os diálogos entre os dois mais fluente e espontânea.

O esconderijo do rosto do ator por detrás da câmera subjetiva realça o caráter velado de seu ato de adultério e de sua vida dupla, acentuando sua discrição. Realça também um caráter contemplativo, delegando ao espectador uma responsabilidade conjunta por esse olhar. O olhar direto de Muriel para o espectador/François seduz ao mesmo tempo que instaura um certo remorso em nossa complacência com François, pois mobiliza uma parcela de identificação que traz à tona a ética de uma escolha conjunta a uma vontade de aventura ou paixão. Mas não se trata da identificação psicológica com o personagem apenas (uma vez que nem vemos seu rosto e nem sabemos ainda nada sobre ele), mas o resultado da interpelação direta que nos coloca de saída em um ponto de vista situado na história. De certo modo é uma limitação, uma seleção ou recorte que vincula a descoberta e a curiosidade do espectador à assertividade e voluntariedade do personagem. O personagem leva o espectador a entrar na história, mas requer deste uma cumplicidade e um julgamento, um papel de testemunha.

A primeira imagem do filme é da rua a partir de uma carro em movimento, cujo ruído já havia se insinuado nos créditos iniciais. O pára-brisa do carro distorce as luzes da rua e o diálogo de um homem e uma mulher revela que ele dá carona a ela. Um corte mostra ela, Muriel, no banco de passageiro, que fita diretamente a câmera em diversos momentos. $\mathrm{O}$ diálogo versa sobre uma festa onde acabaram de se conhecer. A câmera enquadra a moça o tempo todo durante a conversa, o espectador vê a interpelação direta do olhar da atriz, mas não sabe ainda se é um plano próximo que será depois justificado por um contracampo do interlocutor oculto, ou se é uma câmera subjetiva.

A câmera subjetiva aqui é principalmente enfática. A câmera subjetiva tem um apelo emocional evidente, associada ao caráter de sua fixidez demorada e contemplativa. Pois se François está dirigindo seu carro, a demora em fixar Muriel foge do olhar natural de um motorista, que visaria primordialmente o trajeto a fim de dar reais chances a um futuro romance. Mas ela interessa tanto a ele quanto ao filme muito mais que o trajeto que percorrem através de Paris, e a câmera subjetiva fixa-a ostensivamente. Ao chegar ao destino, próximo à casa dela, e após François pedir o telefone dela, um plano de um café aberto é mostrado: apenas a distorção das luzes da iluminação pública ligam este plano aos anteriores da cidade vista através do pára-brisa do carro de François, nem a parte superior do painel do carro é mostrada. É um plano muito curto, que só é justificado subjetivamente pelo contexto narrativo, pois quase nada na imagem refere-se ao ponto de vista subjetivo anteriormente construído, senão as anamorfoses das luzes refratadas pelo pára-brisa do carro. 
Na sequência seguinte, François liga para Muriel para chamá-la para sair. Há diversos movimentos de câmera, panorâmicas que marcam o desvio de sua atenção para fatos corriqueiros de seu trabalho, enquanto fala com ela ao telefone: um funcionário carregando uma caixa, uma secretária que chega para dar um recado e o faz através de mímica, já que ele fala ao telefone; uma olhada de François para seu reflexo em um espelho (fig.18). Há outro plano como o do café, desta vez uma fachada de edifício comercial (fig.19), também imóvel, que só pode ser justificado como visão subjetiva de François a posteriori. Há um contraste evidente com os planos em que, sentado à sua mesa de trabalho, telefona para ela, onde a movimentação de câmera e o escopo visual possuem uma dinâmica dos movimentos de cabeça e das mãos de François.
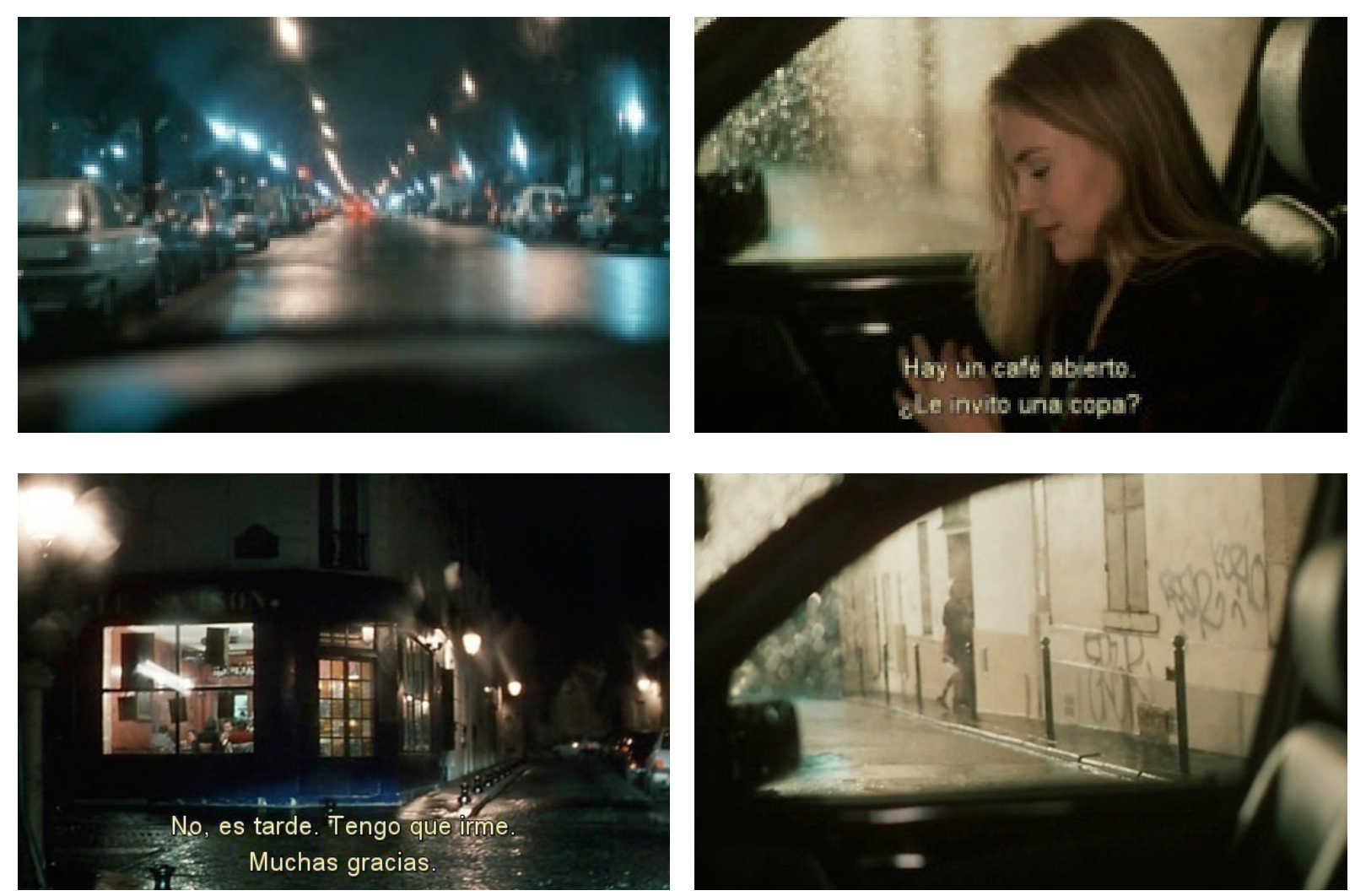

Figuras 14 a 17. Sequência de abertura de La Femme Défendue
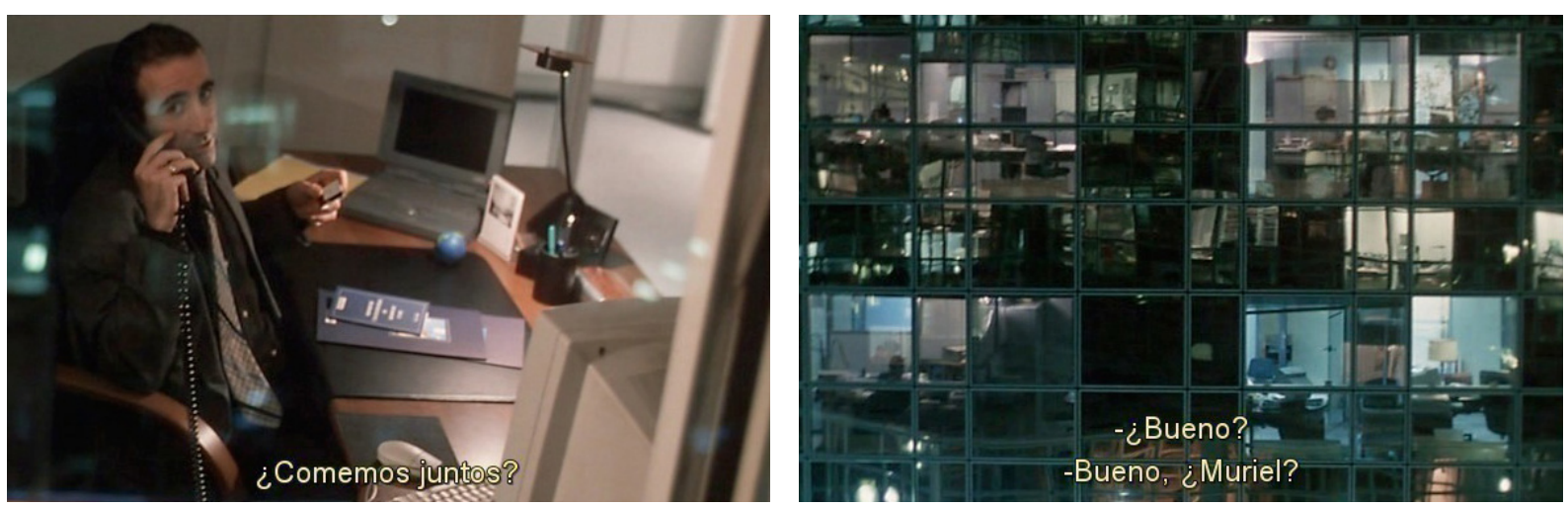

Figuras 18 e 19. Olhares do personagem-câmera que o situam espacialmente. 
Os planos mais soltos, menos vinculados organicamente, sugerem a mudança momentânea da atenção do personagem para aspectos adjacentes ou periféricos à sua situação. As ações de seu trabalho, que ocupam seu campo de visão, ficam subordinadas à fala pelo telefone, a qual ele mantém sem interrupções.

La Femme Défendue de saída assume o ponto de vista subjetivo, apesar de incluir pequenos planos um pouco mais soltos, menos vinculados à situação e à posição do sujeito-da-câmera. A Dama do Lago, diferentemente, inicia com uma interpelação explicativa de Robert Montgomery ao espectador, para introduzí-lo na focalização interna sistemática do detetive Philip Marlowe. Este procedimento acusa uma distância a ser percorrida pelo espectador para que se consume esta identificação e estabelece uma situação interlocutória que põe a diegese entre parênteses, na qual se explicam as regras do jogo vindouro, em um espaço e um tempo determinados, em um passado narrado em flash back.

O antropomorfismo com o qual a câmera se reveste quando simula a percepção natural humana é necessariamente construído de modo a configurar suas próprias regras de funcionamento. A altura e o ângulo de posicionamento, o aspecto de seu movimento de rotação ou translação, sua focalização óptica e aberrações visuais de desfoque ou distorção, são alguns dos parâmetros que procedem na produção imagética a ancoragem na situação da personagem mimetizada e narrativamente justificada. Direções corretas de olhares criam a ilusão de um espaço visual coerente. A sutura já é intrínseca ao próprio plano, plano curto ou plano-sequência, e deixa marcas visuais, indícios na imagem dessa ancoragem perceptual. Por exemplo, a distorção e refração da luz no pára-brisa e a anamorfose radial da periferia do quadro no plano da fachada do café, que situam o ponto de vista dentro do carro (fig.16).

Esta codificação antropomórfica ocular opera no plano e também na montagem. Cortes e raccords são relacionados com movimentos de cabeça, dos olhos, o piscar do olho, ou mesmo sugerem processos cognitivos como a atenção e sua dinâmica. outros exemplos são os cortes
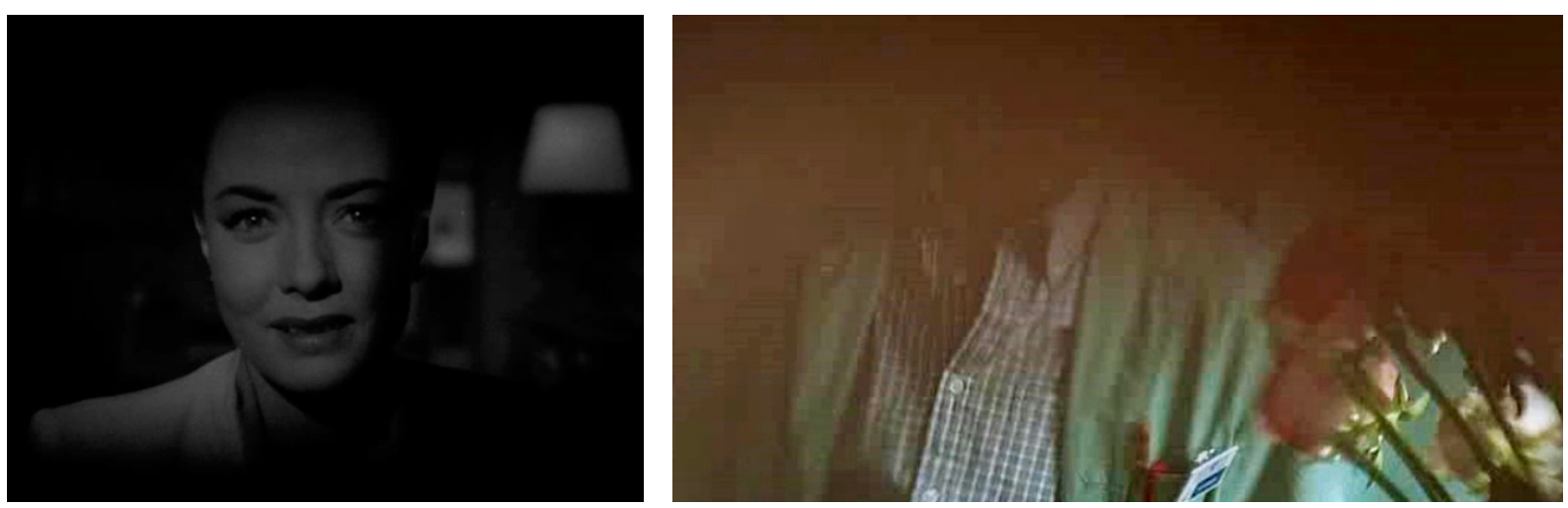

Figuras 20 e 21. Olhos semicerrados em A Dama do Lago e O Escafandro e a Borboleta. 
entre imagens simulando o piscar do olho em O Escafandro e a Borboleta ou Enter the Void. Nestes filmes os cortes tem o papel usual de dinamizar a narrativa com elipses e escapar da sujeição ao plano-sequência, embora utilizem-no amplamente.

Tanto em La Femme Défendue como em O Escafandro e a Borboleta e Enter The Void a continuidade e o parâmetro dos raccords é tanto espacial e temporal quanto mental, isto é, motivado pela atenção e memória do personagem. Embora o primeiro filme seja narrado cronologicamente e os dois últimos não, existem, em La Femme Défendue, cortes elípticos e raccords descontínuos motivados psicologicamente.

A motivação é outro fator responsável pela naturalização do discurso lógico narrativo. Há motivação narrativa em uma câmera quando esta estabelece o tempo da narrativa; o espaço cênico; segue ou antecipa o movimento da personagem ou de um objeto significante; reenquadra algo importante; evita seguir ou reenquadrar por razões de suspense, mistério, surpresa, censura ou gosto; segue ou descobre um olhar; seleciona um aspecto ou detalhe significativo; revela uma faceta da personagem. Se o tempo de narrativa ou de visibilidade na tela for insuficiente ou demasiado, se caracterizará desmotivado. Um movimento de câmera com motivação será transparente com elemento estilístico. Um movimento desmotivado chamará atenção para si desatrelado da história, causando certo distúrbio ou opacidade, que por sua vez, pode ser motivada posteriormente ou retrospectivamente. Além do movimento da câmera, a motivação influi no tamanho dos planos, na pirâmide escalar dos planos e sua relação com o desenvolvimento dramático de uma cena, promovendo afunilamento ou generalização; bem como no vínculo causal entre os elementos da narrativa, como a estrutura campo/contracampo, por exemplo.

\section{2. 2. Maniac, Peeping Tom}

O emprego da câmera subjetiva em Quero ser John Malkovich (Being John Malkovich, Spike Jonze, 1999), cujo título já evoca a identificação, atesta uma passividade nesta identificação promovida pelo ponto de vista subjetivo: uma falta de autonomia ou de comando, a sensação de estar a mercê de outrem, uma vez que todos os que experimentam ser John Malkovich estão alienados de si no interior de um outro corpo. A perda do controle das próprias ações e do controle das ações de outra pessoa reveste-se da alegoria do teatro de marionetes, onde cada indivíduo revela-se um títere nas mãos (e no olhar) de um titereiro superior que o comanda. O titereiro Craig, no escritório onde passa a trabalhar como secretário, faz uma notável descoberta. Encontra um portal que dá acesso ao ator John Malkovich, a seu corpo, suas emoções e pensamentos, por meio do qual qualquer pessoa pode literalmente estar na pele dele. Há uma 
relativização em chave irônica de quem é que verdadeiramente atua por trás do personagem, do ator ou do olhar nominalizado da câmera subjetiva. Este portal, este estreito túnel subterrâneo (uma simbólica vagina que dá à luz uma alteridade) que endereça a imagem a um destinatário que também é remetente (no registro ficcional, ao representar o seu próprio papel, o ator sempre remete a um personagem de si mesmo), se faz visível em imagem com o auxílio da moldura ou vignette (na câmera subjetiva, quando se está na "pele" de John Malkovich), e representa o limite interno deste wormhole.

Maniac, em chave psicanalítica que pretende aprofundar o personagem, mas que acaba por gerar o efeito inverso, tem que encenar o tempo todo este teatro de marionetes, mas estes

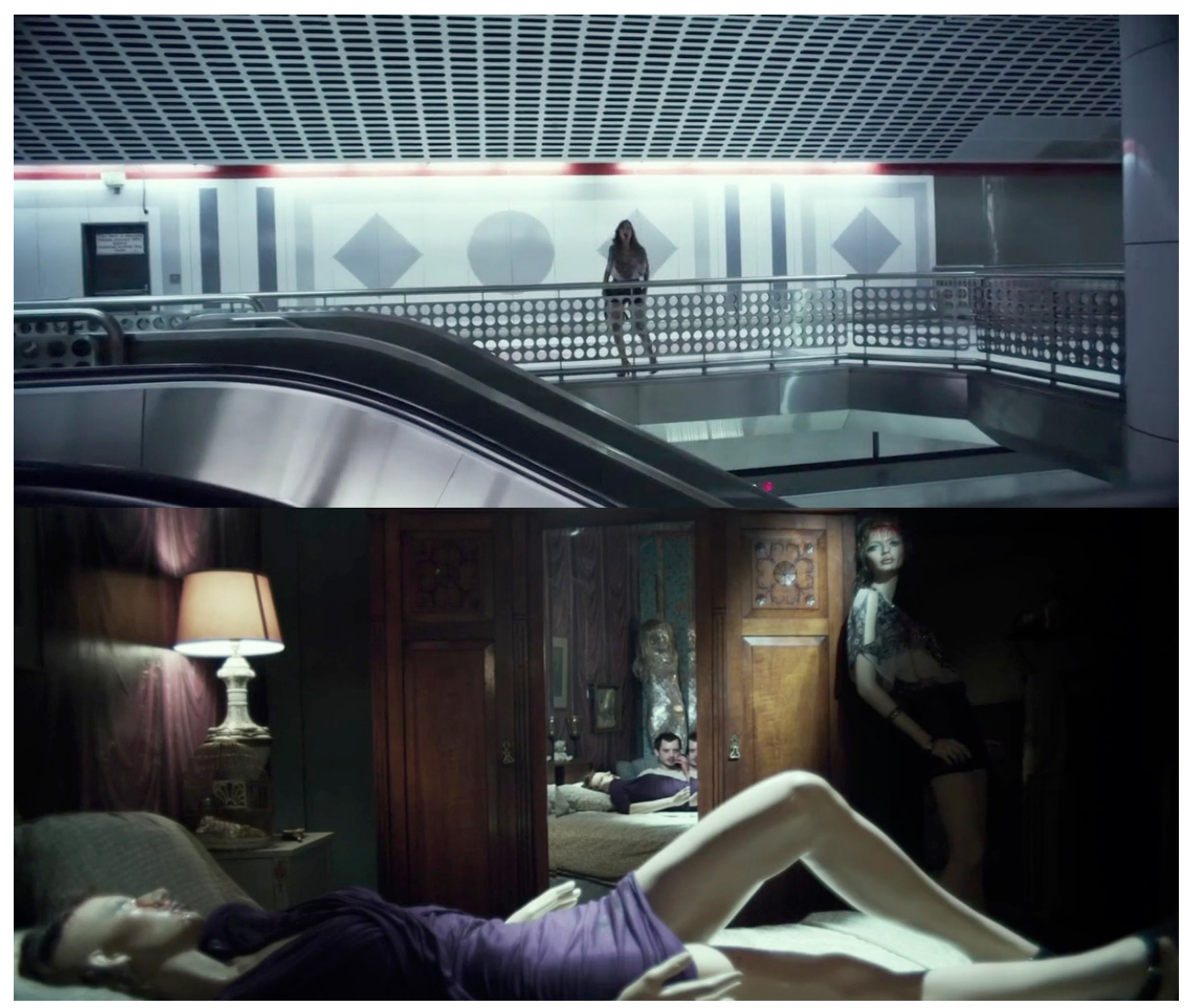

Figuras 22 e 23. Maniac e o uso do eixo de profundidade

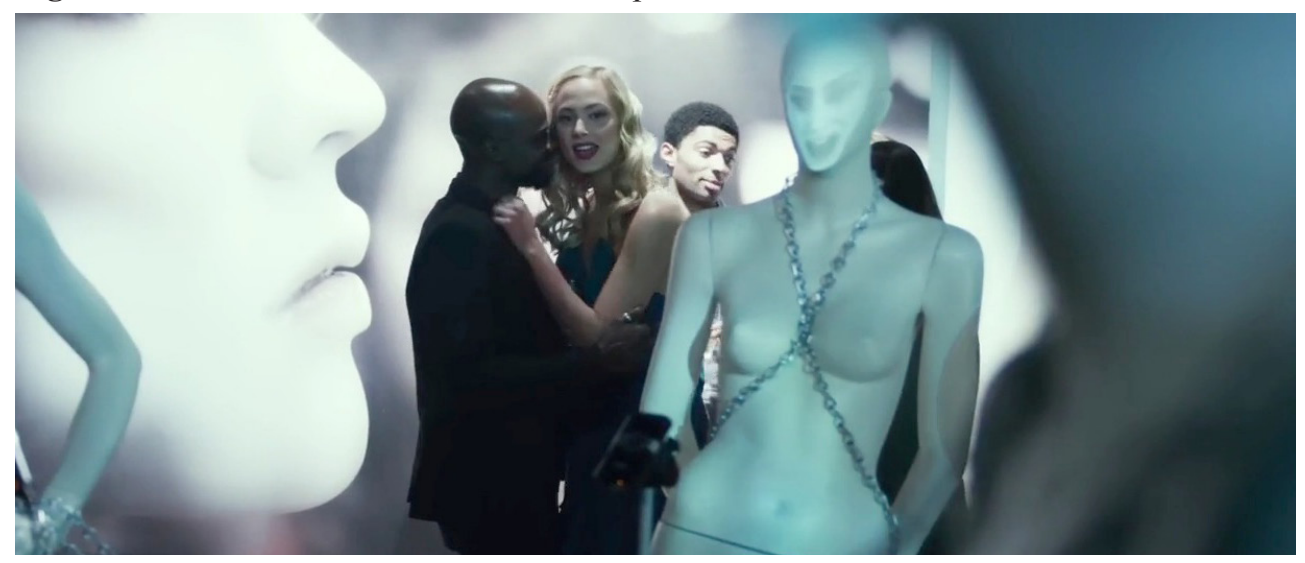

Figura 24. Maniac sobrepõe signos de subjetividade em profundidade na imagem. 
precisam ter carne: precisam de vida e envolvimento, elãs que o maníaco faz questão de perverter em suas relações com suas vítimas.

Maniac (Franck Khalfoun, 2012) replica em imagem o eixo de profundidade que empilha camadas na espessura da imagem, dispõe camadas ou planos de profundidade que correspondem a uma encenação. Esse arranjo operado pela mise-en-scène do filme já é subjetivo: corresponde ao ponto de vista geral da escopofilia do assassino, que é ao mesmo tempo um encenador. $\mathrm{O}$ assassino dispõe dos corpos, para compor (com seus fetiches) a cena que sucederá o clímax anterior com maior expressividade, um novo clímax unicamente visual.

Em Maniac a câmera subjetiva explora a internalidade do personagem como espelho que gera uma imagem virtual: a encenação de imagens substitutas que valeriam por si mesmas, independentes do mundo que as originou, a representação do vivido, mas um vivido para a imagem, para a encenação onde o serial killer representa seus traumas e desejos, em um típico clichê compensatório de sua impotência sexual, derivada do trauma de ver sua mãe tendo relações sexuais com estranhos.

A panorâmica inicial que inicia com uma tomada de uma esquina ("cornerstone"?) da cidade onde um rosto ao fundo observa com expressão atenta, ou mesmo angustiada, pressagiando o pathos do protagonista. A câmera passa a movimentar-se para a esquerda, onde algo
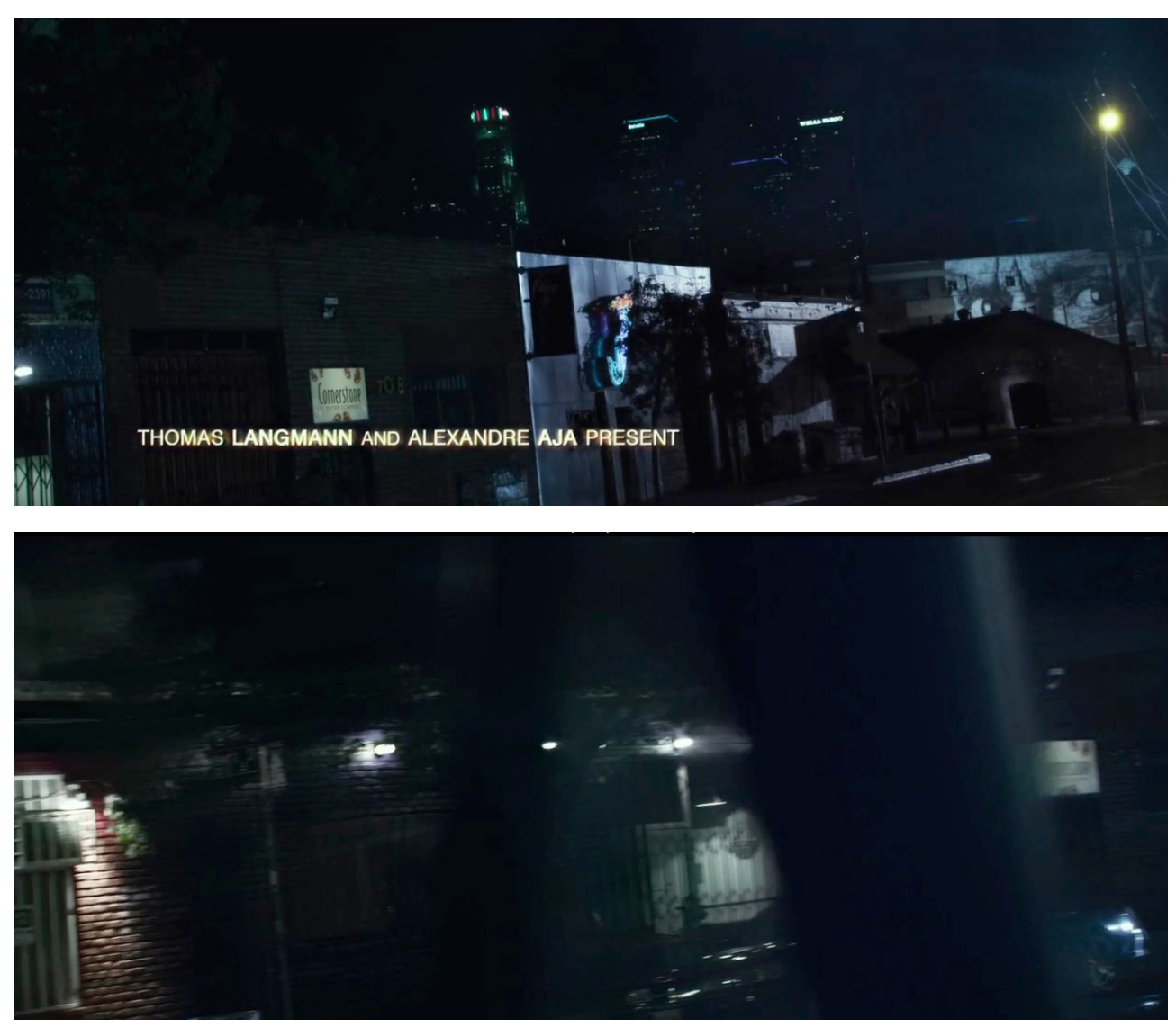

Figuras 25 e 26. Abertura de Maniac, cuja panorâmica situa o POV dentro de um automóvel. 
desfocado se interpõe em um plano bem mais próximo: o que localiza o ponto de vista detrás, ou melhor (quando reconhecemos tratar-se de uma coluna lateral do teto de um automóvel), dentro de algum lugar. A imagem vista portanto, duplica, ou melhor, reflete o ponto de vista: um olhar que espreita em uma esquina da cidade. Este elemento desfocado em plano próximo na profundidade de campo, no eixo focal da profundidade perspectiva da imagem-câmera, é o que nos dá ao mesmo tempo uma localização e uma pessoa: um observador dentro de um carro. É um signo de subjetividade que funciona através da posição e do movimento do observador em relação ao objeto observado. O ponto de vista, pelo seu desenvolvimento espácio-temporal, indica que pertence a um determinado observador situado, cujo olhar compartilhamos.

Estas marcas na imagem, aqui, as partes do carro, colunas, volante, marcas do limpador no pára-brisa, a movimentação pelas ruas, são índicios de objetos ou posições relativas que estabelecem a profundidade espacial e modulam o movimento do ponto de vista dentro do espaço perspectivo.

Peeping Tom é uma clássico do uso da visão subjetiva mediada pela câmera. O fotógrafo protagonista precisa filmar suas vítimas no momento da morte, pois está interessado na expressão do horror diante da morte iminente. Sua câmera de filmagem foi equipada por ele com um objeto perfurante como um espeto ou um arpão acoplado ao tripé, notoriamente fálico, o qual usa para matar enquanto capta as expressões desesperadas de suas vítimas, mulheres.

O lastro psicológico que fundamenta sua pulsão de feminicídio é que sofreu abusos paternos, não sexuais, mas morais. O pai era um cientista interessado no estudo do medo, e para isso submetia seus pacientes a situações abusivas e constrangedoras, inclusive seu filho. Assim, a falta e a castração simbólica advinda da criação seriam as causas do comportamento pervertido do filho, inclusive pelo seu interesse na expressão do medo.

A cena que relaciona seu passado de abusos com a pulsão escópica assassina é mais interessante que a explicação da motivação. Mark, o fotógrafo, é o senhorio do prédio onde habita. Um de seus inquilinos é Helen, uma moça simpática que procura travar amizade com ele. No dia do aniversário dela, convida-o para a festa, mas Mark é tímido e arredio. Ela o visita em seu apartamento e leva bolo para ele. Convidada a entrar, se interessa pela aparelhagem fotográfica de Mark. Sua curiosidade a leva a arguir sobre a procedência do equipamento, e Mark resolve mostrar a ela filmes de sua infância. O ambiente é escuro e as atitudes de Mark são tensas, no fundo não sabemos se simpatiza com ela ou se tem a intenção de matá-la. Claro que matá-la seria inoportuno, pois seria descoberto, uma vez que seus convidados a esperam. Liga o projetor. Junto com o ruído do projetor, soa uma música extradiegética, um piano. O tom da sequência é nostálgico, filme antigo, acompanhamento pianístico. O filme 
que mostra a ela foi feito por seu pai: o menino Mark dorme, mas uma luz intensa em seu rosto o incomoda, levando-o a acordar chorando. Na sequência seguinte, o menino, em cima de um muro, observa um casal namorando, dá umas risadinhas marotas. A moça pontua as imagens com comentários do tipo:

- Garoto levado, devia ter apanhado.

Mas estranha também o interesse do pai de Mark por este tipo de situação para a filmagem. A sequência seguinte é mais estranha ainda. Nela o menino dorme novamente e a luz fica insistindo em seu rosto. Helen está incomodada também:

— Mark, isto é um tipo de piada, não?

— Não, Helen.

Mark, olhando através do rolo de filme rodando no projetor, tem expressão desalentada. Levanta-se para pegar algo.

Um lagarto é atirado à cama do menino. Helen se assusta e grita:

— Nossa! O que foi isso?

O menino acorda assustado com o lagarto sobre ele. Helen torce o nariz. Mark monta a câmera em direção a ela, dizendo que quer fotografá-la assistindo. Ela nega, não entende o que o filme lhe mostra. O menino, assustado com o lagarto, chora.

Mark, rosto colado à sua câmera, olhando cabisbaixo para a imagem projetada: Uma voz sem origem pronuncia:

— Já basta, Mark. Seque seus olhos e pare de tolice.

Helen requer explicações, está desconcertada. Mark também. Sugere que ela vá embora. Sabemos por quê. O filme continua. O menino Mark entra num quarto, um corpo de mulher está estendido na cama.

— Estou dando adeus à... minha mãe. Mark toca levemente o ombro de Helen ao dizer isso.

A música de fundo toma vigor. Mark também.

—Ele filmou isso?

— Sim. A música cresce mais ainda. Mark acrescenta, subitamente animado:

— E isto: seu funeral. E isto: seu enterro. E isto.

Uma moça de biquini, na beira de um lago, caminha em direção à câmera.

— Quem é esta? - pergunta Helen.

A resposta, apesar de esperada, é pouco convencional.

- Sua sucessora. - Ela aparece de mãos dadas com o menino Mark.

— Ele casou-se com ela seis semanas após a sequência anterior. Ela filmou o que vem agora. Está fora de foco. 
A madrasta vem operar a câmera, e o pai vai para perto do menino, mas volta para ajustar o foco. Na imagem, o menino tem em mãos uma câmera, que seu pai lhe deu. A câmera que ele usa para filmar seus assassinatos. Um close-up mostra a mesma sobre uma prateleira. Mark, angustiado, é mostrado ao lado do projetor, que faz sombra sobre o rosto de Helen.

Helen, percebendo sua angústia, insiste para que ele desligue o projetor. A música rodopia. Helen insiste novamente:

— Desligue, Mark!

Ele desliga o projetor, o piano extradiegético cessa simultaneamente. Helen, amedrontada, procura sair do ambiente. Corre para a sala, mais iluminada.

A partir daqui, a conversa retoma um tom normal, Mark explica que seu pai era um biólogo e estava documentando o crescimento de Mark, que nunca teve um momento sequer de privacidade. Mostra os diversos livros que o pai escreveu: "Medo e o sistema nervoso", "A fisiologia do medo", "Ensaios sobre o medo" etc., pesquisando o medo principalmente relacionado à infância.

A sequência da projeção dos filmes de infância de Mark constrói seu caráter simbólico com os elementos cinematográficos. A projeção, as imagens em preto e branco, silenciosas, o acompanhamento do piano pontuando ações e viradas emocionais, criam o tom nostálgico do primeiro cinema. A sequência associa ao protagonista de Peeping Tom o caráter escopofílico do cinema: o voyeurismo, a curiosidade de saber o que segue e o que antecede algo, a lógica explicativa das motivações e do encadeamento narrativo. Mas também seu aparato mecânico, a projeção, a visão mediada pelo aparelho, as lembranças transformadas pela narração, a escuridão da sala, a sombra expressionista do rolo de filme sobre o rosto da personagem, a luz que viabiliza a fotografia, o foco que permite a definição da imagem, tudo passa a ter sentido simbólico nesta sequência. A identificação de Mark com o dispositivo cinemátográfico é realçada.

Os dois matadores de mulheres dos filmes Maniac e Peeping Tom precisam encenar suas perversões. O fundamento psicanalítico em que se baseiam talvez seja o responsável por esta
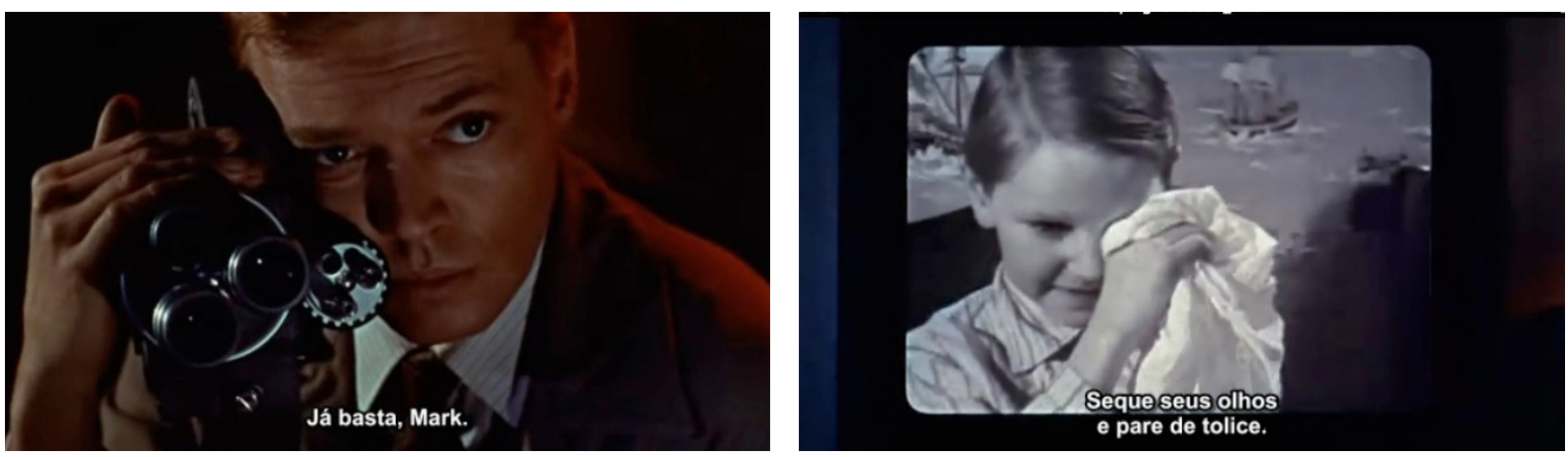

Figuras 27 e 28. Campo e contracampo "suturam" o sujeito através do dispositivo cinematográfico em Peeping Tom. 
chave interpretativa. A visão subjetiva é um recurso que permite ao espectador a "isualização do resultado deste objetivo, a satisfação escópica, nos dois casos, associada à impotência e à repressão sexual. As duas mulheres que interagem com eles, representam a esperança de curá-los da anomalia. Mas o fracasso dessa possibilidade contribui ainda mais para realçar o caráter fatídico da anormalidade desenvolvida. A focalização subjetiva traz para a imagem a estranheza e a singularidade dos personagens pela via do entendimento das motivações psicológicas de suas atitudes e pela mediação que a representação exerce sobre uma percepção incomum ou extraordinária. 


\section{Subjetiva}

"Essa coincidência buscada entre o ponto e o eixo de vista da câmera e os da personagem foi com frequência estudada pela narratologia - para a qual a câmera é menos um olho do que uma materialização da instância narradora. Somos particularmente tentados a aplicar ai a noção, elaborada por Gérard Genette, de "focalização" da narrativa, ou, para levar em conta que há um olhar em jogo, a transpor essa noção para a "ocularização”, como propõe François Jost. O que resulta de todas essas tentativas é, precisamente, a importância da narrativa em toda marcação "subjetiva" do ponto de vista no cinema: que a câmera ocupa o ponto de vista da personagem, eis o que o espectador só pode saber, em regra geral, em virtude do contexto. Contexto da montagem, contexto do fora-de-campo - entre outros,

o fornecido pelo som - sempre contexto narrativo"

Jacques Aumont, $O$ olho interminável, p. 75 
Jacques Aumont, explorando a visualidade comum ao cinema e à pintura, explicita a convenção narrativa do plano-olhar subjetivo, em um tom que ressalta a insuficiência puramente visual deste recurso, na constituição do que ele denomina olho variável. Para ele a narratividade é necessária para a instituição da câmera subjetiva. O sujeito-da-câmera só é designável pelo encadeamento das imagens, pela relação entre as imagens que configura tanto a narrativa quanto a enunciação. O "ponto de vista" subjetivo não é nem absoluto nem isolado, mas participante e contribuinte de uma rede de relações com outros, entre as partes de um "todo" que se define pela própria rede estabelecida, e que se constitui ao se autodesignar como agente de enunciação e criador do acontecimento comunicativo.

O próprio conceito de ponto de vista narrativo e voz narrativa é proveniente da teoria literária e foi aplicado, não sem controvérsias, à narrativa cinematográfica. Paul Ricoeur distingue voz e ponto de vista, no que a voz implica uma comunicação com um destinatário, enquanto associa o ponto de vista à problemática da configuração narrativa ${ }^{17}$. $\mathrm{O}$ ponto de vista media as relações variáveis entre os personagens, as instâncias narradoras e o espectador, entre os diversos níveis que a narração pode assumir.

A expressão ponto de vista subjetivo refere-se a um amplo enfoque narrativo. Um filme pode apresentar-se do ponto de vista subjetivo sem valer-se de um único plano em câmera subjetiva. A expressão câmera subjetiva, engloba o ponto de vista subjetivo narrativo mas possui materialidade visual e auditiva, movimento e tempo próprios.

\section{1. Sujeito enunciador}

A noção de sujeito é noção extremamente controversa, paradoxal. O sujeito, evidência de quem testemunha e pensa, desde Descartes com seu cogito ergo sum, é um centro fundamental. Por outro lado, evanesce ao ponto desaparecer perante os determinismos físicos, biológicos, sociológicos e culturais de uma ciência que se esforçou, se ainda não se esforça, em extinguí-lo, senão diminuí-lo, neutralizá-lo, torná-lo desprezível. “Quem é o sujeito? Trata-se realmente de algo que seja necessário conhecer ou reconhecer? Ou é um epifenômeno, uma ilusão?"18, pergunta Edgar Morin, para logo em seguida propor sua tese.

17 RICOEUR, P. Tempo e Narrativa, tomo 2, WMF Martins Fontes, 2010, p. 172.

18 MORIN, E. in SCHNITMAN, D. F. et alli. Nuevos Paradigmas, Cultura y Subjetividad. Buenos Aires, Paidós, 1998 , p. 69. 
O sujeito é autônomo, e profundamente dependente. Se isto não é visto como contradição, como viam os mecanicismos e determinismos, dependência é inseparável da noção de auto-organização. Um sistema auto-organizador consome energia ao construir sua autonomia, portanto sempre depende do meio externo, não só de energia como também de forma e informação. Seria portanto uma auto-eco-organização, ou melhor, uma organização recursiva cíclica onde os efeitos e produtos são os próprios requisitos de sua causa e produção.

O princípio de identidade que Morin encontra subjacente às formas mais simples de vida pode ser assim formulada: "Eu sou mim mesmo". Cabe esclarecer, para evitar redundância nessa formulação, que a diferença entre o "eu" e o "mim" é que este último está objetivado: o mim, que é a objetivação do indivíduo sujeito, remete ao si, que é a entidade corporal. No si estão incluídos o eu e o mim. Princípio informático, o computo ergo sum ${ }^{19}$ de uma bactéria ao sintetizar DNA realiza um trabalho objetivo com finalidade subjetiva. Esse princípio possibilita a autorreferência: posso tratar de mim mesmo, referir-me a mim mesmo, porque necessito de um mínimo de objetivação de mim mesmo, uma vez que permaneço como eu-sujeito. Só que, assim como a auto-organização é, de fato, auto-eco-organização, igualmente a autorreferência é auto-exo-referência, ou seja, para referir-se a si mesmo há que referir-se ao mundo externo.

A distinção do si e do não-si, que organiza todo sistema imunológico, aceita e rechaça, positiva ou negativa o valor de algo conforme ele lhe ofereça aliança ou ameaça. O princípio de incerteza faz oscilar o sujeito entre tudo e nada: para si mesmo, o sujeito é tudo, centro do mundo, egocentrismo; ao mesmo tempo é nada, efêmero, minúsculo, prescindível.

Morin apresenta uma reconstrução em cadeia do sujeito, necessária para que este não evanesça segundo o paradigma redutor da separação, da disjunção positivista: organização biológica, dimensão cognitiva, cômputo informático dos dados imediatos da percepção, princípios de incerteza, paradoxo e ambivalência, exclusão e inclusão que tornam a noção de sujeito complexa, complicada com o mundo, coalescente, impossível de ser compreendida pelo pensamento disciplinar compartimentado.

Para Paul Ricoeur, caracterizar o si-mesmo é levar em conta tanto a mesmidade quanto a alteridade que o compõem. No âmbito da linguagem, duas abordagens coexistem na operação com estes aspectos complementares do si mesmo, o mesmo e o outro: a referencial e a enunciativa.

19 Ibid., p. 73-76. E nem é mera questão de linguagem que "eu", "mim" e "si mesmo" sejam paradoxalmente idênticos e diferentes, e que a consciência de que "eu sou mim mesmo" opere unicamente para este ser pensante que me considero, pois uma bactéria que não tivesse a consciência (consciência suficiente para ela) disso, não poderia existir, isto é, colocar-se como centro e realizar sua manutenção e salvaguarda, em seu "computo ergo sum" que une o sujeito ao ato de ser finalidade em si mesmo e auto-constituir sua própria identidade. 
Ricoeur considera individualização ou identificação o procedimento no qual se singulariza ou particulariza algo, por intermédio de operadores de individualização, operando por exclusão de um indivíduo às demais classes que o contém por ser portador de um conjunto de características únicas. Os operadores de identificação ou de individualização compõem a referência identificadora. Por tais operadores ele entende os procedimentos de linguagem definidores dos objetos, dos agentes do discurso e das ações, e distingue basicamente três: as descrições definidas, os nomes próprios e os indicadores.

As descrições definidas pretendem individualizar e singularizar pela determinação de características; os nomes próprios singularizam uma entidade mas sem dotá-la de qualidades intrínsecas ao ato de nomeá-las, e os indicadores contém os pronomes pessoais e os dêiticos, que agrupam por sua vez os pronomes demonstrativos, os advérbios de tempo e lugar; os tempos verbais. Os indicadores designam a cada vez coisas diferentes, cujo nexo é estabelecido pela enunciação.

Para a abordagem referencial, cada indivíduo singular possui particulares básicos: seu corpo e sua pessoa. Estes particulares são básicos "no sentido de que não se pode identificar seja lá o que for sem remeter em caráter último a um ou a outro desses dois tipos de particulares" ${ }^{20}$. Corpos são identificáveis, a um só tempo mudam e permanecem os mesmos na duração. No âmbito puramente referencial, sem autodesignar-se, o corpo é uma coisa material como as outras do mundo.

Já para a noção de pessoa convergem a referência identificadora e a autodesignação. Na abordagem referencial "a pessoa fica do lado da coisa de que se fala, e não do lado dos próprios locutores que se designam ao falarem" ${ }^{21}$. Ao falar de si, as duas abordagens convivem simultaneamente.

A enunciação é o campo que permite ao enunciador exercer seu pleno poder de afirmar-se como agente e como sujeito. Os indicadores ou dêiticos se destacam entre os operadores de individualização, principalmente o "eu", que se autodesigna na interlocução em função de um "tu" destinatário. Enquanto na abordagem referencial a terceira pessoa é privilegiada, no papel de algo a que se é referido, em um ato de discurso são as duas primeiras pessoas do singular que adquirem proeminência. Em geral, bastam "eu" e "tu" para configurar uma interlocução.

20 RICOEUR, P. O si-mesmo como outro. São Paulo: WMF Martins Fontes, 2014, p. 6.

21 Ibid., p. 7. 
A enunciação faz notar os vestígios e as marcas da presença do comentador em cada enunciado. Essas marcas, dêiticos, apontam para a instância narradora. Em uma frase como "Estou aqui, agora", é possível identificar alguém que a pronuncia, seu lugar e seu tempo, mesmo que ainda indefinidos. Os dêiticos são expressões cujo referente é determinado somente pelos interlocutores. O termo dêixis tem origem no grego e significa apontar coisas no mundo "com o dedo", possuía um caráter notadamente ontológico. Com o tempo, passou a designar elementos linguísticos que indicassem ou representassem noções de temporalidade, lugar, objetos e pessoas. A dêixis temporal está relacionada ao tempo em que o discurso se dá, principalmente através de advérbios de tempo e por meio dos tempos verbais, pretérito, presente e futuro. A dêixis de lugar refere-se à codificação do espaço em que os participantes se encontram no evento de fala. Pode indicar os locais em que o falante ou o ouvinte estão. A dêixis de lugar é codificada, em geral, por meio dos pronomes demonstrativos e advérbios de lugar. A dêixis pessoal designa o papel dos participantes do ato de fala, os sujeitos da enunciação.

$\mathrm{O}$ ato de enunciação é tratado como um fato, como um acontecimento do mesmo teor que aqueles visados referencialmente por enunciados declarativos ou assertivos. Ricoeur ressalva a limitação de uma abordagem puramente referencial: primeiramente, mesmo que num ato de fala se priorize o próprio ato ao seu agente, e no próprio ato a força ilocutória, ou seja, o que permite analisar o discurso sem levar em conta seu agente, privilegiando a língua e não a fala, essa reflexividade é puramente formal se não acompanha um sujeito real:

1) não são os enunciados, nem mesmo as enunciações, que referem, e sim os sujeitos falantes;

2) a situação de interlocução só vale como acontecimento na medida em que os autores da enunciação são postos em cena pelo discurso em ato e, com os enunciadores de carne e osso, sua experiência do mundo e sua perspectiva sobre o mundo não pode ser substituída por nenhuma outra ${ }^{22}$.

“Eu”, enquanto pronome pessoal, é um termo vacante, um shifter, designa uma pessoa diferente a cada emprego, quem quer que se autodesigne ao falar. Mas, por outro lado, quando empregado por alguém, atesta uma fixação da designação de uma única pessoa que se distingue de todas as demais. Este aspecto sintagmático do emprego do termo, que designa a cada vez uma única pessoa que fala aqui e agora, estabelece "uma ancoragem que remete 
a uma posição não substituível, a um único centro de perspectiva sobre o mundo"23. A ancoragem decorre da assimilação do "eu", sujeito da enunciação, à pessoa, particular básico irredutível; em outras palavras, da relatividade com que dêiticos como "eu", "aqui", "agora", estabelecem com outras coordenadas ao serem empregadas no discurso, e referenciais absolutos, localizados, tais como a data do calendário (dia 25 de julho de 2016), o tempo do relógio (às 13 horas e 53 minutos), o registro civil (Eu, Rodrigo Campos de Oliveira, nascido a 20 de Janeiro de 1976, em Santos, SP).

Através da ação se efetiva o papel do agente. Tanto à ação quanto ao agente adjazem noções de intenção, motivação, objetivo, circunstância, passividade, impulso, etc. Essa rede conceitual que reveste a ação perfaz "um jogo coerente de linguagem, no qual as regras que governam o emprego de um termo formam sistema com as que governam o emprego de outro termo" 24 . Por isso posso investigar uma ação por uma cadeia de perguntas: Quem? Por quê? Como? Quando? Onde? O quê?. As respostas fazem do algo geral um alguém, mesmo que a esse alguém ainda falte a autodesignação.

A visada referencial privilegia as perguntas o quê? e por quê? sobre a pergunta quem?, pois frequentemente dizer o que é a ação é dizer porque ela é exercida. A pergunta por quê?, como guia da ação, privilegia o lado objetivo dela: o resultado atingido, um acontecimento de feições quase impessoais. Por essa via a intenção da ação é distanciada de seu agente. Mas a intenção tem um caráter prospectivo que não é redutível ao fato ocorrido,

"A virtude do raciocínio prático é mostrar um estado de coisas futuro como estágio ulterior de um processo cujo estágio anterior é a ação considerada. $\mathrm{Na}$ expressão: eu faço isso em vista daquilo, a tônica não está em 'eu', mas em 'em vista de', ou seja, na relação de dependência entre dois estados de coisas, um anterior, outro ulterior". 25

A teoria da ação acreditou preservar a especificidade do agir humano tomando já como termo de referência a noção de acontecimento, opondo-o à noção de ação. Para esta teoria, o acontecimento ocorre, e a ação é o que faz ocorrer. O que ocorre é objeto de uma observação e de uma constatação que pode ser verdadeira ou falsa. O que se faz ocorrer não é verdadeiro nem falso, mas torna verdadeira ou falsa a ação executada.

\footnotetext{
23 Ibid., p. 31.

24 Ibid., p. 41.

25 Ibid., p. 58.
} 
Ao acontecimento corresponderia uma causa que o promove, e à ação corresponderia um motivo que faz agir. "Não se pode mencionar o motivo sem mencionar a ação de que ele é motivo" 26 , o que implica logicamente o motivo na ação executada ou por executar. Posso, entretanto, mencionar um efeito sem mencionar sua causa, de modo que há uma heterogeneidade entre os dois: saber qual foi o veneno não muda o fato de que a pessoa morreu envenenada.

O nexo lógico e interno entre motivo e ação ultrapassa as razões de agir exclusivamente racionais. $\mathrm{O}$ afeto ou a paixão, em relação a alguém que age, traz em si a passividade e o desejo intrincados. Mas uma descrição factual ou teleológica do acontecimento costuma ser feita de maneira a dizer-se apenas que o fato de um acontecimento ser necessário a dado fim é uma condição do aparecimento desse acontecimento: "Dizer que um animal espreita a presa é dizer que a espécie de ação descrita como espreita é aquela que, em seu repertório de comportamentos disponíveis, se faz necessária para satisfazer sua fome"27. Desse modo, substitui-se a intencionalidade do agente por uma causalidade teleológica, o que é responsável por um apagamento do sujeito na ação e, consequentemente, da própria ação em favor da sucessão de acontecimentos impessoais.

$\mathrm{Na}$ cadeia de ações e reações que estabelecem uma narrativa, a causalidade que estabelece vínculos entre os acontecimentos não estabelece necessariamente a verdade das intenções iniciais e o resultado lógico das ações e acontecimentos subsequentes. A configuração narrativa opera a mediação entre a diversidade dos acontecimentos e a unidade temporal da história contada, é uma unificação ou síntese do heterogêneo, de modo que inverte o efeito de contingência da ocorrência e incorpora-a em um efeito de necessidade, mas a posteriori.

A composição do enredo e do personagem provêm da inteligência narrativa de um espectador/leitor/ouvinte que une, articula e completa os acontecimentos detentores de uma racionalidade narratológica.

Continua sendo verdadeiro que, do ponto de vista paradigmático, as perguntas quem?, o quê? como? etc. podem designar os termos discretos da rede conceitual da ação. Mas, do ponto de vista sintagmático, as respostas a essas perguntas formam uma cadeia que outra não é senão o encadeamento da narrativa. Narrar é dizer quem fez o quê, por quê e como, estendendo no tempo a conexão entre esses pontos de vista. Também continua sendo verdadeiro que se pode descrever separadamente os predicados psíquicos tomados sem nenhuma atribuição a uma pessoa (o que é a própria condição da descrição do "psíquico"). Mas é na narrativa que se recompõe a atribuição. ${ }^{28}$

26 Ibid., p. 48.

27 Ibid, p. 67.

28 Ibid, p. 153. 
Deste modo, a narrativa confere iniciativa à personagem para começar uma série de acontecimentos e ao narrador o poder de determinar o começo, o meio e o fím de uma ação. Dessa correlação entre ação e personagem, resulta que a dialética interna da personagem também se pauta pela síntese entre a discordância, representada pelas ocorrências contingentes, acidentes, encontros fortuitos, etc., e a concordância retroativa que cria a identidade narrativa. A personagem, entidade indistinta de suas experiências, "compartilha o regime da identidade dinâmica própria à história narrada. A narrativa constrói a identidade da personagem, que pode ser chamada de sua identidade narrativa, construindo a identidade da história narrada" 29 . A narrativa opera assim uma síntese entre a objetividade referencial e subjetividade enunciativa, dotando de caráter temporal o si-mesmo e fazendo convergir suas facetas de mesmidade e de alteridade.

Esta concepção narrativista da identidade da personagem poderia ser confrontada por narrativas nas quais o enredo é posto a serviço da personagem, ou que comportam um eclipse de identidade da personagem que afeta também a conclusão da narrativa, onde à medida que a narrativa se aproxima do ponto de anulação da personagem, vai perdendo suas qualidades de configuração ao mesmo tempo em que a personagem perde suas qualidades de figuração. Estas narrativas diluem o narrar ao privilegiar as descrições, os argumentos e ideias, sensações, frente às ações, e aproximam-se do ensaio e das modalidades de fluxo de consciência, como o filme-ensaio, o cinema de fluxo, etc.

Apesar de estender sua concepção mimética da narrativa a qualquer narrativa, Ricoeur praticamente não menciona o cinema. Meu interesse em sua análise exposta acima é a confrontação entre a abordagem referencial, que compreende as propriedades de imagens e sons, e a abordagem enunciativa, que se refere ao sujeito da enunciação e à sua capacidade se autodesignar como sujeito singular, e as formas que a câmera subjetiva assume ao conformar em um ato de enunciação um acontecimento da subjetividade.

\section{1. 1. Narratologia, enunciação: discurso da câmera subjetiva}

Nos anos 60 e 70, quando uma abordagem linguística predominava nos estudos fílmicos, importava tratar o filme como um texto, de forma que as imagens corresponderiam a enunciados sintagmáticos, o plano ou a sequência básica, como elementos de um encadeamento significante. 
Gianfranco Bettetini abordava o filme como um texto que agenciaria a presença mútua e imaginária de um emissor e de um receptor, configurando uma conversação. Ele partia de uma relação dialógica entre dois pólos enunciativos, um enunciador e outro enunciatário.

Para Francesco Casetti o texto do filme fundamenta uma proposta feita ao espectador, um verdadeiro pacto comunicativo estabelecido pelo encontro de certas expectativas, necessidades e competências do espectador com o texto. Esse encontro se daria tanto através das deixas do texto quanto dos procedimentos interpretativos, mas também no nível cultural, tanto pelo significado textual quanto pelas interpretações sociais ${ }^{30}$.

Francesco Casetti distinguia um discurso fílmico que exibe seus próprios parâmetros de referência, de outro que os camufla em seu discurso. Por um lado, uma enunciação enunciada, através do comentário ou mesmo da interpelação direta ao outro pólo enunciatário (ou alvo da enunciação, como preferia Christian Metz); por outro lado, uma enunciação diegetizada, fundada em um discurso transparente perante a diegese, uma narração que não se destacaria do narrado.

Em seu El film y su espectador, Casetti postula quatro tipos de arquiteturas do olhar no filme. ${ }^{31}$ A primeira é a câmera objetiva, signo de uma escritura neutra e impessoal, calcada sobre o realismo e sobre a valorização da ação representada e, retomando André Bazin, permissiva à liberdade do espectador. Pragmática no que diz respeito à funcionalidade narrativa, a câmera objetiva põe em evidência o representado e supõe um espectador que ocuparia a posição determinada por ela e fruiria seus índices de verossimilhança em estado de anonimato.

O segundo tipo, que ele denomina câmera objetiva irreal, pelo contrário, põe a si mesmo em evidência ao enfatizar o representado, e desvela seu procedimento e sua lógica de seleção do enunciado e de sua importância, fazendo-se sentir em seu exibicionismo ou hiper-realismo. Ao invés do "grau zero" da câmera objetiva, aqui a câmera opera forçando o destinatário implícito nas imagens a "identificar-se com uma máquina em ação, em vez de com um olho separado e externo"32. A opacidade irreal é matéria sensível do filme que aparece entre o olho e o mundo visado: o dispositivo encenador, a fabricação da ilusão que acomete a imagem.

O terceiro tipo, a interpelação, prolonga o enunciador em um narrador: a figura encenada dirige seu olhar ou sua voz para o espaço do outro lado da tela, um fora de campo que constitui

30 CASETTI, F. The eye of the century: Film, experience, modernity. New York: Columbia University Press, 2008.

31 Id. El film y su espectador. Madrid: Ediciones Catedra, 1989, passim.

32 Ibid., 1989, p. 93. 
um ponto de vista e de escuta que jamais será mostrado, e que poderá ser ocupado pelo espectador, um parceiro possível, ou mesmo um cúmplice implicado neste chamado comunicativo.

O quarto tipo, a câmera subjetiva, o filme explicita o fato de dar-se ao espectador, figurativizando sua própria destinação, dando-lhe a função de observador e fazendo-o coincidir com um personagem.

3. 1. 2. Focalização narrativa, entre literatura e cinema, o discurso de um narrador

A narração clássica procura fazer seu narrador discreto em vista dos fatos narrados, de modo que eles dêem a impressão de contar-se por si mesmos. Seguindo o que Henry James defendia para a narração literária, o importante é que o personagem seja um refletor de suas idéias, "uma espécie de centro organizador da percepção, que tenha uma rica sensibilidade, uma inteligência penetrante, para a expressão da qual têm de ser trabalhados coerentemente os outros elementos da narrativa: da linguagem ao ambiente em que se movimentam as personagens"33. Defendendo a verossimilhança (que se distingue da verdade mas que parece ser verdadeira, segundo Aristóteles), Henry James critica a narração em primeira pessoa, privilegiando a narração em terceira pessoa, onde o narrador se camuflaria com mais eficácia. Percy Lubbock, condenando também as interferências do narrador, distinguia narrar de mostrar, no sentido em que mostrar seria relativo à menor intervenção possível do narrador. Desde Lubbock os paradigmas da cena ou do panorama influem no foco narrativo. Sua defesa do ponto de vista objetivo procura afugentar quaisquer subjetividades que venham determinar sua estrutura. Com Jean Pouillon e sua teoria das visões na narrativa, o aspecto da visibilidade ganha reforço. Mas é Norman Friedman quem sistematizará o foco narrativo literário, chegando a incluir a câmera como um elemento do ponto de vista narrativo. Com a categoria da câmera, Friedman apresenta a exclusão máxima do autor, qualificando o dispositivo de captura com uma grau de objetividade e de neutralidade autográfica que, hoje em dia, sabemos ser bastante controverso. A influência do cinema na literatura emprestava conceitos que reverberaram no trabalho de Isherwood, de Dos Passos, bem como no nouveau roman e no trabalho literário e cinematográfico de Robbe-Grillet. John Dos Passos, em Paralelo 42, observa a mudança do paradigma da sociedade americana dos anos 20, pautada na palavra, para a ênfase na visualidade. A década de 20 presenciou uma virada epistêmica baseada em princípios comuns de teorias

33 CHIAPPINI, L. O foco narrativo. São Paulo: Ática, 1989, p. 13. 
da visão e pressupostos da psicologia do desenvolvimento, herdeiras de desenvolvimentos de pesquisas efetuadas no século XIX. Dos Passos chamava de "olho da câmera" o ponto de vista anônimo de alguém não identificado entre os personagens, ponto de vista ideal ou perfeito, vantage point, indissociável da trama, e incorporado em um "observador invisível". Tal como Christopher Isherwood em Adeus à Berlim: "Eu sou uma câmera com seu obturador aberto, completamente passiva, registrando sem pensar" ${ }^{\prime 4}$. Ambos foram influenciados pelo programa estético cinematográfico da kino-glaz de Dziga Vertov, que tratava o cotidiano urbano por um viés revolucionário. Dziga Vertov considerava o cine-olho como um projeto científico. Preconizava o trabalho dos kinoks como reveladores da verdade materialista. Para Vertov, a câmera cinematográfica era superior ao olho humano em suas possibilidades. Seu entusiasmo pela metáfora do olho da câmera exaltava a possibilidade de aprimoramento da visão, como a visão microscópica, a telescópica, a visão de raio-X, as possibilidades de alteração da velocidade de filmagem, inversão do movimento etc. Para ser científico, o cine-olho supunha-se móvel, múltiplo, objetivo e incorpóreo.

Nos textos narrativos, é através da voz do narrador que conhecemos o desenrolar da história e as ações das personagens, mas é através da voz das personagens que conhecemos as suas ideias, opiniões e sentimentos. Discurso diz respeito à narração, segundo Émile Benveniste, é a forma como a voz das personagens transparece na voz do narrador. Há três tipos de discurso, ou seja, três formas de introdução das falas dos personagens na narrativa, a saber:

- o discurso direto, onde o narrador procura isenção na narração e permite que as personagens se exprimam por si mesmas, transcrevendo suas falas e ações, geralmente utilizando sinais de pontuação como travessão ou aspas. Ex.: Ela disse: "- Que calor!”

- o discurso indireto, onde ele não só interfere como media a expressão das personagens, refazendo a essência do que vivenciaram, disseram ou agiram, usando a terceira pessoa. Ex.: Ela disse que estava fazendo muito calor;

- o discurso indireto livre, que não é introduzido por verbos de elocução, sinais de pontuação ou conjunções, borrando o início e o fim do discurso da personagem, confundindo-o, muitas vezes, com o discurso do narrador onisciente. Ex.: Um dia horrivelmente quente. Que calor! Ela suava... 
Para André Gaudreault e François Jost, a enunciação no cinema geralmente mostra ações sem dizê-las, o que não impede que sejam ditas. A instância narrativa aparece, geralmente, menos nítida do que na narrativa escrita, pois à imagem não correspondem os dêiticos encontrados na linguagem verbal. Os acontecimentos parecem contar-se por si mesmos. Impressão enganosa, pois, sem a mediação, não haveria filme.

André Gaudreault e outros chamam de regime de mostração o sistema representativo derivado da mimesis platônica. Pelo seu poder de selecionar o que mostrar, este sistema alude a um narrador ou imagista que estaria por trás dessa condução. Essa instância narradora recebeu diversos nomes por diferentes autores: "grande imagista", "narrador implícito", "narrador invisível”, "meganarrador”, “enunciador” etc.

“O sistema narratológico da enunciação cinematográfica está, então, correlacionado aos fenômenos de crença aos quais a visão de um filme ou de um documento televisivo dão lugar, respondendo a questões como estas: de onde vem a confiança que concedemos às imagens? Que papel tem, na compreensão dos filmes, a ideia que temos do autor?" 35

Temos, do lado de um grande imagista suposto pela lógica da narrativa defendida pela narratologia (o mágico manipulador escondido atrás das imagens, dos sons e da palavra escrita), a teoria narratológica que vai modular a instância narradora através da focalização narrativa, dos níveis de narração, das pessoas da enunciação.

O comentário falado ou escrito do narrador sempre o coloca em evidência, e a montagem remete a um poder de agenciamento exercido pela instância narradora, que reune as imagens sob a bandeira do significado. Seja como dado aparente das imagens, seja como estrutura subjacente a elas, a narração suporia um sujeito enunciador que as agencia no filme.

Haveriam marcas no discurso audiovisual que trazem consigo, no bojo de sua enunciação, os vestígios de quem o articula, exceto através do atos de fala pronunciados por alguém, seja narrador ou personagem, onde a enunciação, em seu sentido linguístico, seria designável? Gaudreault e Jost destacam casos em que a imagem cinematográfica caracteriza um ponto de vista subjetivo ${ }^{36}$ :

35 GAUDREAULT, A.; JOST, F. A narrativa cinematográfica. Brasília: UnB, 2009.

36 Ibid., p. 60-61. 
- distorções ópticas da imagem que se distinguem da visão natural, evocando estados alterados do sujeito que vê;

- partes do corpo próximas do ponto de vista, referências ao corpo de quem vê: cortina de cabelos de mulher, tufo de pêlos de animais, fenda entre dedos de uma mão, mãos e braços entrando em campo no lado inferior do quadro;

- moldura, máscara na imagem: o close-up exagerado de algo em primeiro plano, tornando-se uma mancha desfocada, que sugere proximidade física e através da qual o olho espia. Ex. vão entre ripas de uma cerca;

- materialização na imagem de algo que remeta à qualquer dispositivo óptico: como quando vemos através de um visor, buraco de fechadura;

- o tremido da câmera, que remete ao aparelho de captura, bem como a um corpo em movimento;

- sombra da personagem no campo de visão;

- o ponto de vista até a altura dos olhos de um ser humano, mais baixo ainda se for um animal de pequeno porte;

- o olhar em direção à câmera, a interpelação direta ao espectador.

Denomino signos de subjetividade estas marcas que incidem na imagem caracterizando um olhar subjetivado. O uso da voz em off diegética, sussurrada ou não, é um exemplo sonoro desses signos de subjetividade. O ruído de passos, ou outros ruídos orgânicos como a respiração, que acompanham a câmera subjetiva, associados ao sujeito do olhar ou ao operador da câmera, são outros exemplos.

Às marcas de subjetividade na imagem corresponde uma abordagem referencial do sujeito, enquanto que à autodesignação enunciativa corresponde o encadeamento semântico das imagens e dos sons: só sei que é uma câmera subjetiva pelo que a imagem ou o som manifestam por si mesmos, o que Deleuze chamava de imagens óticas e sonoras puras, e pela montagem, ao articular e exprimir a integração das pontos de vista que compõem o sujeito-da-câmera no devir diegético.

A câmera na altura do olho em movimento dissemina-se na audiovisualidade contemporânea, o POV subjetivo multiplica-se, embora com dificuldades para permanecer narrativo nos moldes clásicos. 
3. 1. 3. Pasolini e a subjetiva indireta livre

Pasolini, em um texto de 1965 intitulado "O Cinema de Poesia", afirma para o cinema um sistema de signos de base rudimentar e onírica que não tem precedentes na linguística. Denominando im-signos esses signos imagéticos, declara não haver dicionário que os compile ou defina. Por isso, a possibilidade das imagens é infinita: o cineasta retira do caos de possibilidades uma imagem e a carrega de uma qualidade expressiva, realizando uma primeira operação de adequar essa imagem a um contexto de significação presumivelmente compartilhado e, a seguir, dotá-la de um estilo e uma singularidade. Isso, segundo ele, caracteriza a transitoriedade do cinema, sempre ligado ao imaginário de uma época, e facilmente sujeito a envelhecer e tornar-se datado.

Mas o caráter compartilhado da imagem transita entre o imaginário e o inconsciente coletivo, em um "patrimônio visual comum" que permite ao cineasta torná-la um sintagma, um signo de uma linguagem simbólica já dotada de uma "história pré-gramatical" ${ }^{37}$.

A imagem e sua materialidade é sempre concreta e nunca abstrata, de modo que o cinema pode ser alegoria ou parábola, mas dificilmente expressa diretamente um conceito abstrato.

Pasolini defende para o cinema a linguagem poética, embora reconheça que a instituição narrativa do cinema faça-o parecer corresponder mais à prosa que à poesia.

Subrepticiamente, a característica irracional sempre extravasou as normatividades impostas ao cinema para torná-lo racional, lógico e ilustrativo: uma potência mítica, onírica e bárbara que escapa à analogia com a linguagem verbal, bem como com a convenção narrativa.

Isso não quer dizer, entretanto, que a imagem cinematográfica não tenha a objetividade que os diferencia elementarmente dos sonhos e que a faça referir-se indicialmente aos objetos da realidade. Mas a operação fundamental do cineasta é primordialmente subjetiva na medida em que é fruto de uma escolha não predeterminada, revestida de uma intenção daquele e derivada de sua visão singular e ideológica. A essa dupla natureza da imagem cinematográfica, Pasolini associa a linguagem da prosa à sua objetividade, e a linguagem da poesia à sua subjetividade.

Para caracterizar esta subjetividade poética do cinema, ele recorre ao discurso indireto livre como sua condição de possibilidade.

Ele entende o discurso indireto livre como a submersão de um autor em um personagem, fazendo uso de suas idiossincrasias para uma expressão mimética de sua psicologia, sua linguagem e seu meio social. O discurso indireto livre, segundo Pasolini, difere do monólogo

37 PASOLINI, Empirismo herege. Lisboa: Assírio e Alvim, 1982, p. 140. 
interior do personagem na medida em que um naturalismo impede o autor de tomar o discurso do personagem como seu, dando voz a uma diferença social entre ambos.

Pasolini afirma que ao discurso direto corresponde a visão subjetiva, a câmera subjetiva, onde o autor apaga sua proeminência "e cede a palavra ao personagem, entre aspas"38. As aspas, no cinema, poderiam ser marcas intrínsecas à imagem ou pertencentes ao jogo enunciativo que determina que àquela imagem mostrada corresponde a visão de um personagem.

Ao discurso indireto livre, por sua vez, relacionaria-se o que ele denomina "subjetiva indireta livre".

Pasolini analisa os modos como Antonioni, Bertolucci e Godard valem-se de personagens para legitimar um estilo expressivo próprio subterrâneo à narrativa. Liberta da função mimética narrativa, um mero "álibi narrativo acidental" 39 , a subjetiva indireta livre se expõe como o estilo e a visão de mundo que o cineasta imprime ao filme, como se fosse um outro filme almejado dentro do filme realizado.

O autor valia-se da primeira pessoa, de personagens hipersensíveis ou neuróticas que, apesar de compartilhar do mesmo status quo social, expunham na crise de comportamento e no irracionalismo um vasto material para a expressão formal de seu estilo.

Tratam-se já de pseudo-narrativas onde o que importa é o pretexto para que a câmera se faça sentir como uma "consciência técnico-estilística" que abriu mão da "transparência", que a escondia na função de somente aderir ao significado. Para ele "os filmes não eram poesias, mas narrativas" ${ }^{40}$ quando a câmera ocupava um lugar, geralmente fixo, em plano de conjunto, que permitia a expressividade da cena e do ator, mas que não se denunciava como expressiva por si.

Exemplificava os usos da câmera neste novo estatuto poético:

- as deformações causadas por diferentes lentes

- o uso da zoom

- contraluzes artificiais e flares em imagem

- travellings

- movimentos manuais de câmera

- jump cuts

- falsos raccords expressivos

\footnotetext{
38 Ibid., p. 144.

39 Ibid., p. 152.

40 Ibid., p.150-151.
} 
Ou seja, todo um vocabulário técnico que ousou quebrar as regras da representação clássica, mas que depressa tornou-se o cânone do cinema moderno.

Pasolini foi o precursor da semiótica do cinema independente da linguística. Para ele, o cinema é uma língua, não uma linguagem, a "língua escrita da realidade". O cinema se assenta num sistema de signos diferentes da linguagem falada, que não remete a uma impressão de realidade, mas à realidade mesma. A dupla articulação que torna o cinema língua é imagética e não linguística, segundo André Parente, foi definida por Gilles Deleuze com o conceito de imagem-movimento. Para Deleuze, a imagem-movimento é determinada como unidade (monema) pela montagem, ao exprimir a "integração de um todo que se diferencia continuamente entre os objetos (cinemas) ou unidades que o compõem"41. A imagem-movimento "fala" através dos objetos e atos da realidade, que são seus componentes.

\section{1. 4. Acontecimento, semiótica da câmera subjetiva}

É o movimento o que caracteriza o cinema e não a narratividade, como fazia a semiologia. O movimento é a unidade consistente do plano que modula a diferenciação das partes e a integração no todo em um regime orgânico.

A semiologia de Christian Metz que reduzia a imagem a um enunciado, o sintagma, que é a unidade organizada pela lógica da ação e da representação a fím de criar o discurso fílmico narrativo. A semiologia apodera-se da matéria sinalética das imagens e determina o aspecto parcial de significação: um ponto de vista, um corte, uma imagem atual, instantânea, um recorte. A sintagmática repousa sobre a idéia de que a imagem cinematográfica teria necessariamente uma significação de antemão e reproduziria a realidade conforme a percepção natural. Qual a consistência entre a analogia da imagem com a realidade preexistente e o caráter convencional do signo linguístico, é algo que a semiologia tem dificuldades em explicar: pois ao reduzir a imagem, e tudo o que ela possui de matéria assignificante, a um enunciado disposto em uma sequência narrativa atualizante, perde-se o movimento e o tempo reais da imagem, transformando-a em código linguístico arbitrário.

André Parente alinha modelos de estudo narrativo que privilegiam o enunciado: os formalistas russos, a narratologia e a teoria mimética de Paul Ricoeur. Segundo ele, para os formalistas russos, a estrutura narrativa é causal e temporal-cronológica, e manifesta-se na práxis, na

41 PARENTE, A. Narrativa e Modernidade. Campinas: Papirus, 2000, p.23. 
mudança consequente das ações exercidas em um estado de coisas designado ${ }^{42}$. A sequencialização narrativa obedece à uma lógica da ação concatenada, e possui uma estrutura linguística destacável e independente das circunstâncias e das técnicas que operam em um dada história. A designação é a dimensão do enunciado privilegiada por eles, dentro de uma linguagem da prosa de ação e reação.

Para a narratologia, o narrador, o responsável pela narração, manifesta-se a respeito do que sucede e a conduz, explícita ou implicitamente. Para Gérard Genette toda narrativa, segundo Parente, é produzida em primeira pessoa, e sua especificidade narrativa reside em seu modo e não em seu objeto. A manifestação ou enunciação deste narrador mais ou menos implicado, sempre existente mesmo oculto, é a dimensão principal do enunciado defendida por esta corrente, a prevalência do discurso da narração. A narratologia trata, por um lado, com o nível da ficção, ou a organização do conteúdo do filme: a história contada, as ações e os papéis das personagens, as relações entre os actantes; e por outro lado, com o problema do discurso, da enunciação: o ponto de vista, os níveis de narração, temporalidade da narrativa etc.

A narratologia fílmica acrescentou interrogações acerca da especificidade de uma linguagem cinematográfica, além de retomar as categorias da narratologia literária, como o tempo, o ponto de vista e a narração. Da perspectiva narratológica, assim como em todas as formas de narração, a narração fílmica também presume a comunicação de informações narrativas entre duas instâncias situadas cada uma em uma ponta da cadeia. O narratário de uma narrativa é aquele ou aquela a quem ela é destinada, submetido a um processo comunicacional no momento em que o narrador fornece para aquele uma variedade de informações sobre o universo diegético onde evoluem os personagens da narrativa e as ações que eles realizam.

Para Ricoeur, como diz ainda Parente, a narrativa é a significação sintética dos eventos acontecidos, um relato a posteriori não decorrente do ato de enunciação de um narrador, nem de um estado de coisas designado, mas de um processo de reconhecimento do necessário e do universal operado pela constituição narrrativa, onde a intriga é a unidade sintética que, a um só tempo, integra os acontecimentos num todo, e, num processo de diferenciação, os distribui e ordena ${ }^{43}$.

Para André Parente, duas concepções da narrativa audiovisual rivalizam: uma é fazer tanto da imagem quanto da narrativa sistemas de representação, a outra é e considerar a imagem e a narrativa acontecimentos, onde estes resultam da própria imagem. Parente defende uma

42 Ibid., p. 32.

43 Ibid., p. 33. 
abordagem que não parte dos enunciados, e que não considera na imagem somente seu valor de enunciado.

Em um sistema de representação a imagem circula num regime de semelhança, de continuidade, de referência, em um estatuto de veracidade. Como acontecimento, a imagem prescinde do vínculo a um referente, ela é o referente de si própria, enquanto parte intrínseca do mundo.

$\mathrm{O}$ efeito de real da situação confere veracidade à narrativa, tornando uma narrativa verídica. A narrativa verídica é aquela que considera o acontecimento que a constitui como preexistente a ela, "ela é apresentada como se tivesse sido, em um dado momento, presente" ${ }^{44}$. A realidade autônoma, pré-formada, pré-configurada em relação a esta percepção, que dela vai selecionar o que lhe interessa e, no mesmo ato, atribuirá ou extrairá do fluxo um suplemento de sentido. A imagem captada pelo olho da câmera parte de uma realidade profílmica ${ }^{45}$, sobre a qual exerce um processo de arquivamento de reprodução ${ }^{46}$, que registra o que se passou diante dela. Mesmo que opere na tentativa de um grau zero de interpretação desta realidade, pelo próprio fato de exercer uma seleção, um recorte, uma duração, há sempre uma interpretação, por menor que seja.

Segundo André Parente, a narrativa verídica tem desde Aristóteles relação com a retórica e o sistema jurídico, onde o juízo é intrínseco à narrativa dos fatos. Na narrativa verídica o inteligível surge do contingente e do acidental, assim como o necessário surge do episódico. Existe um controle da rede conceitual da ação, onde as designações de quem fala e qual sua implicação no acontecimento relatado são fundamentais ${ }^{47}$.

Para Parente, a oposição narrativo/não-narrativo constitui-se um falso problema. Em primeiro lugar, porque o cinema não tem uma natureza linguística, mas imagética. A narrativa não é um enunciado que representa um estado de coisas; ela não é a representação ou a relação de um acontecimento, ela é o próprio acontecimento. Em segundo lugar, os processos formadores da imagem são, a um só tempo, imagéticos e narrativos. Há a narração consubstancial às imagens e aos sons, decorrente de suas materialidades, que não se opõem ao sentido, mas comportam sentido em sua própria substância. São processos imagéticos e narrativos ao mesmo tempo,

\footnotetext{
44 Ibid., p. 53.

45 Que esteve diante da imagem captada, presente no momento de sua realização.

46 GAUDREAULT, A.; MARION, P. O fim do cinema?: uma mídia em crise na era digital. Campinas: Papirus, 2016 , p. 105. Aspecto alográfico da gravação ou filmagem, na qual não haveria nenhuma transcendência ou atribuição de suplemento estilístico ou artístico, mera captação e restituição do real, segundo André Gaudreault e Philippe Marion. Étienne Souriau denomina afilmico este aspecto.

47 Ibid., p. 34.
} 
sem prevalência de um sobre o outro. Trata-se de processos narrativos não-linguísticos. Para esta semiótica, não se trata de reduzir imagem e narração a enunciados analógicos. Segundo ela são falsas as oposições imagem/narrativa, figura/discurso, sentido/forma, comunicação/poética, significado/significante, narrativo/não-narrativo, nas quais os primeiros termos conviriam aos cinemas narrativos clássicos e os segundos termos ao cinemas experimentais. As falsas oposições como cinema realista/cinema de ficção, cinema do sentido/cinema da forma ou do significante, cinema da significação/cinema da imagem, são o resultado de uma má compreensão tanto da narrativa quanto do cinema.

André Parente deve a Gilles Deleuze os fundamentos de suas reflexões acima. Deleuze fala a Pascal Bonitzer e Jean Narboni:

"Pensadores como Metz ou Pasolini fizeram uma obra crítica importantíssima. Mas neles a referência ao modelo linguístico sempre acaba mostrando que o cinema é outra coisa, e que, se é uma linguagem, é uma linguagem analógica ou de modulação." 48

Para o filósofo francês é o trabalho de modulação de uma matéria não-linguística que o cinema opera:

\footnotetext{
"A semiologia, de inspiração linguística, tende a fechar sobre si o "significante", e a separar a linguagem das imagens e dos signos que constituem sua matéria-prima. Chama-se semiótica, ao contrário, a disciplina que só considera a linguagem em relação a esta matéria específica, imagens e signos. Claro, quando a linguagem se apodera da matéria ou do enunciável, ela faz deles enunciados propriamente linguísticos que já não se exprimem em imagens ou signos. Mas mesmo os enunciados, por sua vez, se reinvestem em imagens e signos, e fornecem de novo o que é enunciável." 49
}

O enuncíavel é este aspecto da imagem que não se conforma a um enunciado. Deleuze conclui em seu A imagem-tempo:

"O cinema não é língua, universal ou primitiva, nem mesmo linguagem. Ele traz à luz uma matéria inteligível, que é como um pressuposto, uma condição, um correlato necessário através do qual a linguagem constrói seus próprios "objetos" (unidades e operações significantes). Mas esse correlato, mesmo inseparável, é específico: consiste em movimentos e processos de pen-

48 DELEUZE, G. Conversações. Rio de Janeiro: Editora 34, 1992, p. 70.

49 DELEUZE, G. A imagem-tempo. São Paulo: Brasiliense, 2011, p. 312. 
samento (imagens pré-linguísticas), e em pontos de vista tomados sobre esses movimentos e processos (signos pré-significantes) (...) A língua tira daí enunciados de linguagem com unidades e operações significantes, mas o próprio enunciável mais suas imagens e signos são de outra natureza." 50

Respondendo sobre a validade dos conceitos vindos de outras disciplinas e aplicados ao cinema, discorre sobre a narração no cinema:

\begin{abstract}
"Ora, poderia dizer-se o mesmo da linguística: ela também se contenta em trazer conceitos, que, vindos de fora, se aplicam ao cinema, como por exemplo o sintagma. Mas com isso a imagem cinematográfica é reduzida a um enunciado, e se coloca entre parênteses seu caráter constitutivo - o movimento. A narração no cinema é como o imaginário: é uma consequência muito indireta, que decorre do movimento e do tempo, e não o inverso. O cinema sempre contará o que os movimentos e os tempos da imagem lhe fazem contar. Se o movimento recebe sua regra de um esquema sensório-motor, isto é, apresenta um personagem que reage a uma situação, então haverá uma história. Se, ao contrário, o esquema sensório-motor desmorona, em favor de movimentos não orientados, desconexos, serão outras formas, mais devires que histórias." 51
\end{abstract}

Deleuze, dessa forma, reverte a primazia da narratividade cinematográfica para uma consequência das imagens e dos sons. Mas como fica o sujeito-da-câmera sem a narrativa que o constituia, sem o esquema sensório-motor que faz o personagem agir, olhar, e permitir a adesão do espectador a este personagem, noutras palavras, a câmera subjetiva? Como esta é possível sem a configuração narrativa que atribuia, referia e designava as ações aos seus sujeitos, os pontos de vista aos personagens?

A percepção ${ }^{52}$, para Henri Bergson, é voltada para as coisas, reflete minha ação possível

50 Ibid., p. 311.

51 Op. cit. 1992, p. 77.

52 ABBAGNANO, Nicola. Dicionário de filosofia. São Paulo: Martins Fontes, 2007. Segundo o Dicionário, a concepção de percepção exposta por Bergson assim se situa: "O conceito de percepção ao qual essas doutrinas fazem referência é bastante uniforme: a percepção é o ato pelo qual a consciência 'apreende' ou 'situa' um objeto, e esse ato utiliza certo número de dados elementares de sensações. Este conceito, portanto, supõe: $1^{\circ}$ ) a noção de consciência como atividade introspectiva e auto-reflexiva; $2^{\circ}$ ) a noção do objeto percebido como entidade individual perfeitamente isolável e dada; $3^{\circ}$ ) a noção de unidades elementares sensíveis. $\mathrm{O}$ abandono desses três pressupostos caracteriza a nova fase do problema da percepção, própria da psicologia e da filosofia contemporâneas" (p. 754). Segundo a acepção contemporânea, percepção é a interpretação dos estímulos, o reencontro ou a construção do significado deles. É possível distinguir dois grupos de teorias: a) as que insistem na importância dos fatores e das condições objetivas, e negam as sensações elementares que compõem um objeto, e mesmo a existência de um objeto isolável, como a Gestalttheorie, para a qual a percepção sempre se refere a uma totalidade cujas partes separadas não apresentam as mesmas características que em conjunto; b) as que insistem na importância dos fatores e das condições subjetivas, como a disposição do sujeito para a percepção, pela qual 'estar disposto para certo estímulo e para certa reação a um estímulo facilita o ato de perceber e possibilita a sua realização com maior prontidão, energia ou intensidade. A disposição (...) é um processo seletivo que determina preferências, prioridades, diferenças qualitativas ou quantitativas naquilo que se percebe: não é um mecanismo inato ou prefixado, mas um esquema variável aprendido ou construído, ainda que nem sempre voluntariamente'. (p. 755) 
sobre elas, identifica o necessário para que eu possa agir sobre o mundo e a partir dele. Tanto o mundo como suas partes são imagens, materiais. Matéria e imagem equivalem-se. A imagem-matéria é a variação acentrada da ação e da reação imediatas de uma imagem sobre a outra, um fluxo material. Haveria uma percepção da matéria sobre ela mesma, onde não se poderia falar de consciência, a menos que um intervalo nesse fluxo fizesse a matéria refletir sobre si mesma: uma tela ou anteparo, um centro de indeterminação, uma imagem privilegiada, seletiva. Bergson escreve em Matéria e Memória ${ }^{53}$ :

Ora, eis a imagem que chamo de objeto material; tenho a representação dela. Como se explica que ela não pareça ser em si o que é para mim? A razão é que esta imagem, solidária à totalidade das outras imagens, continua-se nas que a seguem, assim como prolongava aquelas que a precedem. Para transformar sua existência pura e simples em representação, bastaria suprimir de uma só vez o que a segue, o que a precede, e também o que a preenche, não conservando mais que sua crosta exterior, sua película superficial. O que a distingue, enquanto imagem presente, enquanto realidade objetiva, de uma imagem representada é a necessidade em que se encontra de agir por cada um de seus pontos sobre todos os pontos das outras imagens, de transmitir a totalidade daquilo que recebe, de opor a cada ação uma reação igual e contrária, de não ser, enfim, mais do que um caminho por onde passam em todos os sentidos as modificações que se propagam na imensidão do universo.

A representação seria uma faceta particular do mundo objetivo que interessa a nossa percepção, que nos permite agir sobre ele.

Eu a converteria em representação se pudesse isolá-la, se pudesse sobretudo isolar seu invólucro. A representação está efetivamente aí, mas sempre virtual, neutralizada, no momento em que passaria ao ato, pela obrigação de prolongar-se e de perder-se em outra coisa. O que é preciso para obter essa conversão não é iluminar o objeto, mas ao contrário obscurecer certos lados dele, diminuí-lo da maior parte de si mesmo, de modo que o resíduo, em vez de permanecer inserido no ambiente como uma coisa, destaque-se como quadro ${ }^{54}$.

Mas a percepção só é possível graças a um intervalo nesse fluxo material que liga as coisas do mundo entre si. O intervalo entre o fluxo contínuo da ação à reação e da reação à ação, permitiria a constituição de um centro ou corpo, anteparo que serviria de fundo para a revelação da imagem. Bergson continua:

53 BERGSON, H. Matéria e memória. São Paulo: Martins Fontes, 1999, p. 33.

54 Ibid., p.33-34. 
Ora, se os seres vivos constituem no universo "centros de indeterminação", e se o grau dessa indeterminação é medido pelo número e pela elevação de suas funções, concebemos que sua simples presença possa equivaler à supressão de todas as partes dos objetos nas quais suas funções não estão interessadas. Eles se deixarão atravessar, de certo modo, por aquelas dentre as ações exteriores que lhes são indiferentes; as outras, isoladas, tornar-se-ão "percepções" por seu próprio isolamento. Tudo se passará então, para nós, como se refletíssemos nas superfícies a luz que emana delas, luz que, propagando-se sempre, jamais teria sido revelada. As imagens que nos cercam parecerão voltar-se em direção ao nosso corpo, mas desta vez iluminada a face que o interessa; elas destacarão de sua substância o que tivermos retido de passagem, o que somos capazes de influenciar. Indiferentes umas às outras em razão do mecanismo radical que as vincula, elas apresentam reciprocamente, umas às outras, todas as suas faces ao mesmo tempo, o que equivale a dizer que elas agem e reagem entre si por todas as suas partes elementares, e que, consequentemente, nenhuma delas é percebida nem percebe conscientemente. E se, ao contrário, elas deparam em alguma parte com uma certa espontaneidade de reação, sua ação é diminuída na mesma proporção, e essa diminuição de sua ação é justamente a representação que temos delas ${ }^{55}$.

Para Gilles Deleuze, Bergson conceitua a imagem-movimento simultaneamente ao nascimento do cinematógrafo. Para Deleuze, a imagem-movimento é um corte móvel dentro de um todo ou de um fluxo. O que Deleuze chama de imagem-percepção é o recorte seletivo operado por alguma instância perceptiva. Mas a percepção tem tanto como referência o todo quanto o intervalo que a proporciona, ela pode ser objetiva ou subjetiva. A imagem-percepção poderia ser denominada objetiva "quando a coisa ou ou conjunto são vistos do ponto de vista de alguém que permanece exterior a esse conjunto" mas nada garante que este ponto de vista ${ }^{56}$ não possa revelar-se como interior ao conjunto do qual parecia estar excluído, de modo que é uma definição "possível, mas exclusivamente nominal, negativa e provisória" 57 . A imagem-percepção passa constantemente de um pólo objetivo a outro subjetivo. Deleuze propõe uma definição bergsoniana para afastar-se de uma definição meramente nominal:

"Será subjetiva uma percepção em que as imagens variem em relação a uma imagem central privilegiada; será objetiva uma percepção tal como existe nas coisas, em que todas as imagens variam umas em relação às outras, sobre todas as suas faces e em todas as suas partes. Estas definições

55 Ibid., p. 34.

$56 \mathrm{Na}$ noção de ponto de escuta, onde o ouvido é este ponto ao qual relacionam-se a espacialidade e a orientação de um som, cujo fenômeno é denominado estereofonia, a mesma consideração também é válida.

57 DELEUZE, G. A imagem-movimento. São Paulo: Brasiliense, 1985, p. 95. 
não apenas asseguram a diferença entre os dois pólos da percepção, como a possibilidade de passar do pólo subjetivo ao pólo objetivo. Pois, quanto mais o próprio centro privilegiado for posto em movimento, mais ele tenderá para um sistema acentrado onde as imagens variam umas em relação às outras, e tendem a juntar-se às ações recíprocas e às vibrações de uma matéria pura. $\mathrm{O}$ que é mais subjetivo que um delírio, um sonho, uma alucinação? Mas o que há também de mais próximo de uma materialidade feita de onda luminosa e de interação molecular?" 58

O olho, variável ${ }^{59}$, móvel, escalar, perspectivo, variaria em relação a centros mais privilegiados que ele, corpos com os quais se comunica materialmente, substancialmente, que o enredam em percepções mais complexas, que o prolongam em sensorialidades mais integradoras, em corpos mais complexos, que dotam este olho de particularidades, de características marcantes, de idiossincrasias, de potências, que o dotam, de ipseidade ou individualidade. Ou então, este olho varia em relação a centros menos privilegiados que ele, ou mesmo nem centros, mas o próprio fluxo, acentrado e diferencial. E o fluxo então captado e processado pela tela-retina é tão mais objetivo quanto mais transmite o movimento, mesmo ao preço de impossibilitar qualquer distinção de suas partes: pois que a seletividade é fundamento da imagem, sempre um recorte maior ou menor, mais ou menos móvel, mais ou menos instantâneo ou duradouro.

58 Ibid., p. 101-102.

59 AUMONT, J. O olho interminável - Cinema e Pintura. São Paulo: Cosac Naify, 2011. A noção de olho variável fundamenta a relação entre o cinema e a pintura. Historiando sua genealogia, Aumont ressalta a contribuição de meios de transporte como o trem para a configuração móvel e veloz desse olho variável situado em um espectador imóvel, como um passageiro de trem olhando através da janela. Ele ressalta também o papel dos panoramas na constituição do aspecto de onividência do olho variável, como o de um espectador imóvel situado no centro de um panorama, sobre a plataforma circundada pela grande imagem representada pictoricamente. 


\section{2. Sujeito expandido: O Escafandro e a Borboleta e Enter the Void}

O Escafandro e a Borboleta relata eventos, de forma não-linear, adjacentes ao derrame que acometeu Jean-Dominique Bauby, enquanto viajava de carro com seu filho. Privado dos movimentos de seu corpo, consegue apenas mover os olhos. E com o piscar do olho que lhe restou, consegue escrever um livro sobre sua nova condição. O uso expressivo do ponto de vista subjetivo da câmera, bem como de sua movimentação ou fixidez, no caso do filme de Schnabel, remete ao cinema como escritura, operação e agenciamento do dispositivo corpóreo-comunicativo pelo sujeito entranhado, como um fantasma preso em uma concha.

Em O Escafandro e a Borboleta, o piscar é ao mesmo tempo, a comunicação possível e o estatuto cinematográfico da disjunção entre o sujeito e seu corpo-olhar. O gesto de piscar os olhos é central na concepção de câmera-olho do filme de Julian Schnabel. Construído com breves "pontas pretas", como se dizia nos tempos da moviola, inseridas na edição ou geradas na captação com a mão do cinegrafista tapando a objetiva, o piscar materializa duplamente o corpo do personagem em chave realista e o nível simbólico da articulação cinematografia/modo de comunicação. Schnabel explora o aspecto involuntário do piscar de olhos como corporeidade que tenciona outro piscar, agora voluntário, como comunicação.

A abertura do filme mostra o despertar de Jean-Dominique do coma. O filme remonta as experiências de Stanley Brakhage para uma visão fílmica que prescinde da identificação, do reconhecimento resultante das convenções representativas. Imagens borradas e anamorfoses, modulação e perda de foco, intervalos, cortes irracionais trazem a dimensão sensorial da percepção se organizando num corpo. Um progressivo ajuste visual, aliado a uma consciência em voz over, um monólogo interior, inferem um indivíduo que os suporta, e que reavalia sua própria condição de existência. Uma relação de interior e exterior aqui se estabelece: uma subjetividade ajustando-se a uma nova configuração de seu corpo, uma adaptação viva do homem ao seu Unwelt.

A estrutura do filme todo passa por essa revisão. Alternando sequências de ponto de vista subjetivo com rememorações, tomadas objetivas de Jean-Do vão sendo introduzidas. A eficiente estratégia de identificação do espectador com a personagem coincide com uma crescente expansão das perspectivas de visão. A distribuição da informação desenvolve o senso periférico da personagem que, a medida que estabelece atividades comunicativas, passa a se ver de um ponto de vista quase objetivo.

$\mathrm{Na}$ sequência que retrata o colapso de Bauby, enquanto dirige com seu filho a seu lado, a câmera mimetiza o gesto corporal de alguém pedindo socorro. Como aqui a câmera não se 
confunde com o olhar de Jean-Dominique, é possível interpretar seu movimento como signo expressivo da busca de ajuda. A câmera fora do corpo estaria sujeita às emanações emotivas da personagem e daria direção às emoções da atmosfera da cena. Oscilando entre o confinamento estacionário e a livre soltura, a câmera-corpo articula o experimentalmente indisponível. Torna a cinematografia uma forma de escrita do invisível pelo visível. A câmera é uma ponte, um elo de ligação entre o protagonista e o que o circunda.

Em entrevista a Nicolas Schmerkin no ano de 2009, quando seu filme foi selecionado para o Festival de Cannes, Gaspar Noé revela sua inspiração para a criação de Enter The Void:

“(...) quando eu tinha uns 23 [anos], assisti a A Dama do Lago [Lady in The Lake, Robert Montgomery, 1947] usando chá de cogumelos. É um filme inteiro filmado do ponto de vista do personagem principal e, sob o efeito da psilocibina, eu fui transportado para a TV e para a cabeça de Marlowe, mesmo o filme sendo em preto e branco e legendado. Eu achei aquela técnica de filmagem através dos olhos do personagem o artifício cinematográfico mais bonito que poderia existir e se um dia eu fosse fazer um filme sobre a vida após a morte, eu iria filmar através da visão subjetiva do personagem." 60

Oscar, estadunidense que vive em Tóquio com a irmã, se envolve com tráfico de drogas pesadas no país. Denunciado por um colega em uma dívida, Oscar é pego em uma emboscada feita pela polícia dentro de um bar e, tentando se livrar da droga que carregava, é morto.

O filme relata as últimas horas da vida de Oscar e sua peregrinação post morten, na qual revisita seus antecedentes. O DJ Oscar vive em Tóquio com sua irmã Linda. Os irmãos perderam os pais num acidente de carro quando pequenos. Oscar usa drogas e faz pequenos tráficos. Seu amigo Alex introduziu-no ao DMT e ao Livro Tibetano dos Mortos. Ao fazer uma entrega da droga, é denunciado e morto pela polícia japonesa. Segundo o Livro Tibetano dos Mortos, como Alex revela a Oscar enquanto se dirigem ao bar onde será morto a tiros pela polícia japonesa, o espírito de um morto terá de cumprir algumas etapas até que encontre as condições propícias para a reencarnação. O filme apresenta a visão de um espírito que desencarnou de seu corpo e fica vagando pela cidade e por suas memórias, numa espécie de limbo, até encontrar um novo corpo onde possa e queira encarnar novamente. $\mathrm{O}$ filme toma o ponto de vista do personagem principal, mas esse ponto de vista transcende os limites humanos. O POV tem a mobilidade de um espírito desencarnado, simbolizando a separação entre 
sujeito e mundo, percebida enquanto condição de pertencimento ao mundo. Assim, o espírito ficará preso ao mundo até que evolua e possa dele se desprender.

A peregrinação do espírito pode ser interpretada como o efeito da droga ingerida pela personagem, e é entremeada por alucinações, embaralhamentos temporais, constantes transubstancializações, deslocamentos espaciais, flutuações. Mas conserva o ponto de vista subjetivo com um rigor obstinado, aliando espacialidade e fluidez num perspectivismo mutante e ostensivo.

A procura de vínculos e respostas motiva e justifica a sucessão temporal do filme, não-linear, e a espacialidade fluida. O espírito de Oscar, condenado a uma exterioridade de seu próprio corpo, configura-se como uma mente expandida que supera distinções entre interioridade e exterioridade, bem como entre dimensões físicas e mentais; uma visão que oscila entre um olhar incorporado e uma visão cosmológica, abordagem que excede o escopo fisiológico rumo à neurologia e a bioquímica. A perspectiva aérea da câmera, que sobrevoa os acontecimentos, pode também mergulhar nos pormenores das reminiscências e do espaço físico, mostrando as passagens entre memória e matéria, entre macrocosmo e microcosmo. A energia vibrante que percorre essas passagens, este fluxo, atravessa a cidade, a parede, se introjeta no ralo, no feto, na luz. Este fluxo é também o da câmera, subjetivada, obrigada a transitar e percorrer o detalhe em busca da onisciência.

A construção do espaço diegético corresponde às coordenadas da imagem quanto ao deslocamento, velocidade, amplitude, distância, resolução, alcance óptico, telescopia e microscopia, perspectiva angular da visão, etc. As fronteiras visíveis das dimensões compossíveis são atravessadas por esse olho variável, móvel e transformável, que perscruta um universo pluridimensional. Enter the Void registra experiências que vão além da individualidade e da intencionalidade. A representação de estados alterados e transcendentes da consciência se vale das imagens digitais de caráter biomédico, do videogame e da visualização arquitetural tridimensional.

Se destaca no trabalho de câmera o vínculo da visão de uma personagem aliada a uma mobilidade ostensiva que caracteriza a fluidez de um espírito imaterial. É um contexto narrativo de visão subjetiva, mas que é relativizado por seu próprio sistema, ao desterritorializar a percepção do personagem-espectador da utilidade e eficiência da economia narrativa, para uma disposição mais contemplativa do espaço.

O trabalho da movimentação de câmera e efeitos especiais deste filme foi inspirado em obras predecessoras como Lady in the lake, de Robert Montgomery; Angst, de Gerald Kargl, com cinematografia de Sbigniew Rybczynski; 2001, Uma odisséia no espaço, de Stanley Kubrick; Altered States, de Ken Russell; Taxi Driver, de Martin Scorsese, segundo as declarações do cineasta. 
Gaspar Noé já havia feito um trabalho de câmera em plano-sequência em seu longa anterior Irreversível, que exibia a sucessão diegética em narrativa reversa. O uso de gruas, da plongée ou picado, da tomada aérea, do posicionamento zenital da filmadora, da rotação do eixo do olhar, se afastam de um antropomorfismo do olhar, enquanto o piscar da imagem e a posição da câmera na altura da cabeça remetem a esse antropomorfismo, usados propositadamente de acordo com a intenção momentânea do filme.

O piscar do olho, neste filme, é ao mesmo tempo ato involuntário e construção visual da incorporação do sujeito diegético em seu papel enunciador ou narrador, no que a visão da personagem compartilha com o dispositivo inscrito materialmente na imagem. Como princípio estrutural da visualidade e da montagem, remonta dimensões de significação imanentes e conceituais, pertencentes à situação sensório-motora das personagens, bem como ao nível simbólico do agenciamento cinematográfico da diegese. $\mathrm{O}$ flicker anuncia o expediente do piscar associado à visão subjetiva do protagonista. Este piscar da imagem é o de seu olho, em um registro antropomórfico e fisiológico, que naturaliza a imagem. $\mathrm{O}$ olho da personagem nos dá acesso ao mundo representado.

John Huston dizia que no filme, tal como no pensamento, realizar cortes é como piscar os olhos. Elidir o desinteressante, eleger o relevante. Walter Murch completa: piscar auxilia uma separação interna de pensamentos, é um reflexo involuntário que acompanha a separação mental do que está acontecendo de qualquer forma. O ritmo e a frequência de piscadas marcariam a imersão do interlocutor no assunto, do ator no personagem, do público no filme, etc. Nosso ritmo de piscar é mais controlado pelo estado emocional e pelo pensamento do que pelo ambiente atmosférico que seca nossos olhos. Além da descontinuidade imanente ao processo do sonho, a vigília também operaria por intervalos e interrupções: “Temos que transformar a realidade em uma descontinuidade visual, do contrário ela iria nos parecer uma linha de letras sem separação por palavras ou pontuação quase que incompreensível" ${ }^{61}$.

A abertura dos créditos iniciais apresenta uma profusão de fontes de estilos diferentes que, longe de afirmar uma roupagem única para o filme, dota-o de multiplicidade e excesso. A rapidez com que estes créditos são mostrados não permite a leitura completa, e constitui um ritmo frenético que alude à iluminação das boates e discotecas: luz piscante e extremamente colorida, associada ritmicamente à música eletrônica e aos efeitos sonoros de tensão elétrica. A música inicialmente é um pulso de textura tensa que prepara a explosão rítmica em que os créditos da equipe serão vislumbrados, obedecendo a uma estrutura típica da música eletrônica.

61 MURCH, W. Num piscar de olhos. Rio de Janeiro: Jorge Zahar, 2004, p. 68. 
Associada à variação de estilos do design das fontes, que incorporam elementos gráficos extravagantes, é impressa à textura desses elementos o flicker, a piscada instantânea e contínua que será quase uma constante neste filme. Essa "flicagem" aumenta ainda mais o ritmo frenético da apresentação dos créditos, fazendo esta parecer mais uma exibição pirotécnica e sensorial do que obedecer à função informativa comum à maioria dos filmes. Se alguém quisesse conferir todas as funções exercidas pelos realizadores do filme, teria que necessariamente pausar o fluxo das imagens.

O flicker, por sua vez, usado como efeito narrativo sensorial neste caso, é um fenômeno resultante da frequência de frames sucessivos na imagem audiovisual. Podem causá-lo no cinema taxas menores que 24 quadros por segundo. Em monitores de tubo de raios catódicos (CRT), frequências menores ou iguais a $60 \mathrm{~Hz}$, também podem causar a percepção dos intervalos entre os campos sucessivos das linhas de varredura, perceptíveis por alterações do brilho da imagem. Isso está intrinsecamente relacionado à percepção do olho humano para intervalos e permanências de estímulos visuais em uma sucessão rápida de imagens discretas.

O efeito de pisca-pisca, o flicker, cria interrupção e alternância entre as imagens. O plano é impregnado de corte, criando uma tensão visual, uma vibração de micro-cortes que afetam o olho num ritmo frenético. Ver e não ver quase ao mesmo tempo. O cinema sempre se valeu disso.

Esta tensão, este tônus que atravessa as imagens e os sons, o pulso elétrico do neon colorido e a batida eletrônica da música propõem uma avalanche sensorial para o espectador. Exigem deste a permissividade ou a entrega, caso contrário torna-se quase intolerável submeter-se a esse excesso de estímulo.

A cor também é um veículo privilegiado deste tônus. O espetáculo da saturação cromática e do hiper-realismo atravessa a cidade e as fronteiras dos espaços exteriores e interiores da subjetividade da personagem. A cor vibrante associada ao piscar abre passagens entre as dimensões paralelas, atuais e virtuais, presentes e passadas.

Cor-luz. Mais que a cor das coisas mesmas, é uma cor que as ilumina. Trata-se do fenômeno de síntese aditiva. A cor não é um fenômeno físico. Não é uma propriedade do objeto, mas um fenômeno fisiológico, de caráter subjetivo e individual. Um mesmo comprimento de onda pode ser percebido distintamente por diferentes pessoas, por outros seres vivos. Atribuo aos objetos cores que não são as que aparecem para mim em minha percepção num dado instante, pois a cor que vejo é sempre o resultado de uma síntese, não necessariamente a que vejo no momento. Mas o cinema também não é a percepção natural.

Enter the Void é uma demonstração constante de que a mudança de cores das fontes de luz artificiais que o permeiam, traz em si esta insistência que nossa percepção dota os objetos, 
ao estabelecer para eles uma constância cromática, uma invariabilidade que é a mais pura ficção de realidade: estabilidade da aparência como propriedade do objeto.

O neon é a matéria energética que dá forma à cidade de Tóquio. A representação da cidade de Tóquio como símbolo arquitetônico da tecnologia de informação, remonta às sinfonias urbanas como as de Walter Ruttman, de Dziga Vertov ou de Jean Vigo. A cidade é retratada como fluxo dinâmico de energias materiais, tecnológicas, sociais e biológicas. Ultrapassando barreiras físicas e mentais, a câmera se move através de caminhos associativos gerados pela energia elétrica, pulsional e sexual, que como o néon, são as veias da cidade, canal de fluxos vibratórios.

A maquete feita pelo amigo de Alex, colada com DMT, torna a droga o composto que administra e une diferentes modos de realidade que perpassam a cidade, uma heterotopia da cultura digital. O DMT, dimetiltriptamina, componente alucinógeno da ayahuasca e da jurema, mas que também é sintetizado pelo corpo humano, é um neurotransmissor que tem papel fundamental em estados de percepção incomuns. Rick Strassman especula que a glândula pineal seja a sua produtora no corpo humano, que a molécula tem participação na produção de sonhos, e que, no momento da morte, seja liberada em massa no organismo. Segundo sua tipologia de experiências induzidas pelo uso do DMT, no nível pessoal pode vivenciar uma transformação de seu relacionamento com seu próprio corpo, a propriocepção, como, no nível denominado invisível, sair do corpo e se encontrar com sólidas realidades coexistentes com a nossa. Pode finalmente, no nível transpessoal, pode transcender a consciência pessoal e experimentar a própria morte.

Enquanto vibração, a cor relaciona-se, de alguma maneira, com o som musical. Tonos, em grego conjuga a qualidade de tensão, firmeza e elasticidade com o tom, no sentido musical e sensorial. Pois o tom alcançado por uma corda em vibração é a medida correspondente de sua tensão e elasticidade, ativadas pelo movimento.

Quando duas ondas idênticas, de mesma frequência, amplitude, comprimento de onda, direção, mas sentidos opostos, sobrepõem-se em um tubo fechado ou em uma corda com as extremidades fixas, criam um padrão de vibração estacionário. O sistema apresenta pontos fixos chamados nós, e pontos de máxima variação chamados ventres. Isso caracteriza um movimento harmônico que as ondas adquirem ao serem excitadas, correspondendo a certas frequências, chamadas frequências de ressonância. A menor frequência de ressonância é chamada de frequência fundamental e produz um primeiro padrão de onda estacionária. A divisão proporcional dessa frequência fundamental dá origem a outras frequências de vibração que correspondem a outros harmônicos dessa fundamental. 
Enter the Void pulsa como uma onda estacionária vibrando entre vida e morte, tornando intercambiáveis os pares deslocamento/fixidez, realidade/imaginário, figurativo/abstrato, plano-sequência/montagem, fazendo o olho da câmera variar fluente, interminável, pelo filme, através dos nós e ventres que faz ver.

Para Christian Quendler ${ }^{62}$, O Escafandro e a Borboleta e Enter the Void revisitam noções tradicionais da narrativa fílmica baseadas na subjetividade. Mas, ao invés de situar a experiência narrativa no âmbito pessoal, ambos expandem o escopo narrativo incluindo nas dimensões sub-individuais correlações entre a câmera e o olho. Tanto O Escafandro e a Borboleta como Enter the Void expandem a noção de sujeito atribuída à personagem de ficção através de estados do corpo e de consciência extraordinários. À consciência encarcerada no corpo de um e ao espírito desencarnado do outro, os filmes polarizam oposições à percepção humana, contestando a ideia de que o cinema a simularia.

O uso da câmera subjetiva em Enter the Void já aponta para uma configuração que transcende o antropomorfismo.

Na maioria dos filme o espectador não se importa em saber quem o faz ver, supondo uma visão sem mediação. Roger Odin atribui esta irrelevância da mediação como efeito de uma leitura ficcionalizante ${ }^{63}$ do filme. A leitura documentarizante ${ }^{64}$, pelo contrário, supõe alguém que de fato está presente no ato da filmagem por detrás da câmera, participando e criando o acontecimento fílmico pela presença real no espaço profílmico.

Uma câmera, segundo Edward Branigan, não deve ser encarada com um centro no filme, mas um efeito disperso de sua rede cognitiva. Não apenas como um objeto profílmico, mas como hipótese de leitura espacial exercida pelo espectador. A câmera torna-se uma entidade que pode ser posicionada em cada cena pelo efeito das reações e associações que fazemos ao assistir o filme. É uma espécie de consciência-câmera, que assume diferentes níveis de imersão ou participação na diegese, no universo fílmico, e permeia variavelmente filme e espectador. Para Branigan, ela pode aparecer em diversos lugares, não somente o designado pela câmera de filmagem utilizada. "O sentido do enquadramento existe dentro do fluxo interpretativo do espectador" ${ }^{\circ}$. Ou mais adiante: “A câmera não é nem uma máquina nem uma testemunha in-

62 QUENDLER, C. Subjective Cameras Locked-in and Out-of-Body. Image [\&] Narrative, v. 15, n. 1, 2014. p. 74.

63 Em francês, fictiviser, fictivisation, lecture fictionnalisante, mode fictionnalisant.

64 Em francês, lecture documentarisante, documentarisation. Roger Odin descreve estes modos ou leituras como transversais ao binômio estanque ficção/documentário.

65 BRANIGAN, E. Projecting a Camera: Language-Games in Film Theory. London, New York: Routledge, 2006, p. 21. 
visível dos fatos, mas um aspecto de uma subjetividade coletiva, e é algo entre objeto material e subjetividade interpretativa, entre mundo e linguagem"66.

Na câmera intradiegética, o personagem-cameraman põe seu corpo a serviço da realização do filme, colocando-se como testemunha ocular do acontecimento registrado. A máquina e o personagem compartilham as mesmas coordenadas espácio-temporais, tem reciprocidade diegética entre si e entre os outros personagens. A câmera é um instrumento a ser manuseado em prol do próprio filme que ajuda a construir. Seu realismo e verossimilhança atestam a preexistência profílmica, mas ao mesmo tempo uma seleção e um encadeamento do material filmado torna tudo artifício: de modo que o espectador ao invés de perceber "eu estou vendo isso", assim percebe: "isso me é dado a ver".

A visada é uma instância onde a identificação, o compartilhamento e a troca são agenciadas. Se, pelo efeito de real e pela ilusão de que a história conta-se por si mesma, a transparência da identificação é almejada, o agenciamento é velado, subentendido. Por outro lado, se a câmera se faz sentir, hiperbólica, alterando e transformando o real, mostrando os componentes da imagem, a construção da encenação, a tessitura dos sons, os movimentos descentrados, a dimensão autográfica de criação do acontecimento é enfatizada.

A câmera aparece como instrumento de percepção, aparelho de gravação e agenciamento, uma instância polivalente de trocas maquínico-subjetivas. O personagem, parte máquina, parte ser vivo, seu olho é já uma câmera, implantada ou acoplada: Hardcore Henry, Robocop, O exterminador do Futuro, V.H.S. 2. Pode ser uma câmera acoplada em um capacete, como no episódio dos zumbis também de V.H.S. 2, ou em Afflicted; ou mesmo uma câmera convencional operada por um ou mais personagens. A câmera subjetiva não pode ser mais normalizada ou justificada perante a objetividade, mas passa a ser a forma singular como o mundo pode ser construído por ela, por sua insistência e ostensividade. O material filmado, se encontrado, é revelador de uma situação passada, mas é pleno acontecimento atualizado. Se é uma equipe de filmagem, é um acontecimento fílmico, são as condições para que o filme aconteça como seu próprio objeto temático, como é o caso de Symbiopsychotaxiplasm. Neste filme a potência falsificante é o filme se valer de sua própria incerteza e incompletude, de suas próprias deficiências e faltas.

Falsos documentários valem-se do testemunho para se auto-referendar, outros filmes valem-se dos aparelhos para se multiplicar e compartilhar pontos de vista; estilhaçam o espaço-tempo da narrativa para ganhar em fluxo e dinâmica.

66 Ibid., p. 93. 


\section{First Person Shot}

É preciso talvez pormenorizar as distâncias entre o POV subjetivo, que se aproxima livre e indiretamente da visão do sujeito que visa, e o first person shot. O ponto de vista variaria em graus que o levam de uma subjetividade mais estrita a uma mais geral, ao ponto de objetivar-se, de não pertencer a ninguém. Este alguém subjacente ao ponto de vista é a medida do agenciamento audiovisual da espessura das imagens, sons e textos, mas é um modo de ver que antecede e condiciona este agenciamento com um corpo perceptivo, um body sensor, segundo Ruggero Eugeni, referindo-se ao first person shot.

Para Alexander Galloway, o POV não leva em conta a fisiologia da visão, nem o embodiment, ao referir-se a um olhar subjetivo, criando uma aproximação que não pretende parecer com a visão ocular nem recriá-la:

$\mathrm{Na}$ cinematografia tradicional, o plano-ponto-de-vista sempre ignora a fisiologia da visão. O que ocorre ao invés disso é um tipo de ponto de vista por procuração, um plano que tem o mesmo vetor da linha de visão do personagem mas na realidade é mais como uma câmera num tripé do que a visão real de um personagem. O plano-ponto-de-vista é um plano de visão abstrato, um ícone que vale pela visão de um personagem. Ele finge estar no ponto de vista do personagem, em sua perspectiva, não exatamente em seus próprios olhos, com todas as piscadas, perdas de foco e movimentos bruscos - sem mencionar a pura subjetividade - que isto acarreta. ${ }^{67}$

Galloway se refere às máscaras como "POV mascarado" (masked POV) e critica nesse efeito a simulação da visão binocular ausente no cinema e sua convenção pouco aderente à fisiologia óptica. Funcional como evidência imagética que investe a percepção do eixo visual que as atravessa, estas máscaras caracterizam-se pela utilização pontual e momentânea. No caso de bordas de imagem desfocadas, ou de imagens de de cartas ou bilhetes mostrados em plano próximo, estariam, para ele, a meio caminho entre o POV e o plano subjetivo, e seriam remanescentes dos intertítulos do primeiro cinema ${ }^{68}$.

67 GALLOWAY, A. R. Gaming: essays on alghorithmic culture. London, Minneapolis: University of Minnesota Press, 2006, p. 41.

68 Ibid., p. 42. 
O plano subjetivo (subjective shot) para Galloway assim se define:

Vamos considerar em detalhe o tipo de plano-ponto-de-vista que simula a visão ocular de um personagem em particular: o plano subjetivo. Como outros planos-ponto-de-vista, planos subjetivos se dão quando dois dos olhares, o olhar da câmera e o olhar de um único personagem, se integram como um só olhar. Os planos subjetivos são ainda mais extremos em sua simulação fisiológica da visão real, no que imitam emanar dos olhos de um personagem mais do que se aproximar de sua linha de visão simplesmente. Dessa forma, os planos subjetivos são muito mais inconstantes. Eles se deformam e balançam. Ficam cegos pela luz e se desfocam. Diegeticamente, eles evocam o "quarto olhar" de Willemen com frequência, onde os personagens interpelam a câmera ( tentando manter a ilusão que a câmera é realmente um personagem) ${ }^{69}$.

Ele segue a distinção feita por Edward Branigan que, nos mesmos termos, reivindica para o plano ou câmera subjetivos a ancoragem no corpo do personagem, de modo que o plano subjetivo se caracterizaria mais por uma dificuldade de ver do que pela clareza perceptiva:

No caso da visão do personagem, o que é importa não é tanto que este veja algo, mas que experiencie a dificuldade em ver. O que se revela não é o objeto exterior do olhar nem um estado interno do personagem, mas a condição do olhar em si mesma. Este recurso da visão do personagem é explorado na estrutura da percepção (isto é, subjetiva) que difere do plano ponto-de-vista em um aspecto importante: no ponto de vista não há indicação da condição mental - o personagem apenas está "presente" - enquanto que no plano subjetivo da percepção há a adição de signos da condição mental (da personagem) a seu ponto de vista ${ }^{70}$.

Então, o POV seria o reverso da moeda do campo/contracampo, o plano comum onde se vê o que alguém vê; e a câmera subjetiva o plano mais raro onde importa a qualidade da percepção, suas circunstâncias e singularidades, e que de certa forma atesta um estado de exceção.

Mas este olhar subjetivo pode ser ostensivo, permanente, e passar de uma cessão da voz e do olhar do narrador para o personagem a uma estruturação mais fechada da diegese. Este ponto de vista subjetivo passa a ser ser sistemático, e se reveste de um corpo adjacente que encarna esse olhar de maneira constante e móvel no universo fílmico.

Assim passa a haver uma tripla coincidência: o autor passa a ser o próprio personagem, o que permite ao espectador vivenciar a criação do acontecimento fílmico por seus próprios olhos. A superposição dos olhares do espectador com o personagem, que torna o narrador autodiegético,

69 Ibid., p. 43. Tradução minha.

70 BRANIGAN, E. Point of view in the cinema. Berlin: Mouton Publishers, 1984, p. 80. Tradução minha. 
excede o regime clássico. Pois neste a coincidência dos pontos de vista do espectador e do personagem são agenciados por um narrador que opera instâncias autônomas, relativamente objetivas.

O uso sistemático da câmera subjetiva, menos comum, extrapola seu emprego convencional na maioria dos filmes. Um determinado ponto de vista, usado sistematicamente e continuamente, orientando a totalidade ou uma parcela majoritária da duração do filme, estabelece coordenadas de inserção perceptiva e cognitiva para seu espectador proporcionando um modus operandi singular: este usufrui dos dados materiais e lógicos que a organização do filme dispõe para sua experiência e compartilha as estratégias de produção de subjetividade propostas pela enunciação fílmica, e sofre os efeitos de presença que a imagem em movimento mobiliza pelo índice fotográfico, seu estilo de apresentação, do desenho sonoro que a acompanha.

Além dessas duas figuras, haveria uma terceira denominada first person shot. Tanto Galloway como Eugeni fazem a genealogia desta figura, mas lhe concedem estatutos diferentes: se para Galloway ela mobiliza a ancoragem antropomórfica, para Eugeni ela se reveste principalmente do seu aspecto maquínico.

Segundo Ruggero Eugeni, o first person shot seria uma figura semiótica que traria consigo o índice da máquina de captura. Na genealogia desta figura, intervieram a profusão, diversificação e popularização de câmeras assim como uma cultura de exposição da imagem digital, facilitadores de produção e divulgação, que criaram as condições de cristalização de novas figuras estilísticas derivadas do manuseio e emprego dos dispositivos como câmeras portáteis, microcâmeras, steadicam, câmeras de vigilância, drones, jogos em primeira pessoa, etc.

O steadicam implica um olhar subjetivo na medida em que é contíguo ao corpo que o suporta e movimenta, em uma escala e ancoragem humana.

A handicam incorpora em sua imagem e som captados as qualidades da imagem tremida; da pequena latitude de exposição à luz, que gera superexposição ou subexposição; da baixa resolução da definição da imagem; da grande profundidade focal; características amplamente associadas à documentários, filmes de baixo orçamento, filmes militantes, registros in loco de protestos, guerras, acontecimentos inesperados, catástrofes, etc., associadas ao efeito de real.

A terceira série de inovações relacionadas por Eugeni à constituição do que ele define por first person shot inclui as microcâmeras, adaptadas à veículos, capacetes, bem como celulares. Remetem a filmes caseiros, eventos sociais, esportivos, filmagens casuais e despretensiosas, registros factuais, etc., amplamente utilizadas e divulgadas, também relacionadas a uma presença testemunhal.

Os equipamentos de vigilância e de espionagem também contribuem para a consolidação desta figura audiovisual, pela sua presença ostensiva e ubíqua, seu caráter de discrição e invi- 
sibilidade, bem como as propriedades de monitoramento contínuo, de agrupamento em rede e de transmissão à distância.

Finalmente, os jogos de videogame em primeira pessoa, que cada vez mais aprimoram-se em termos de realismo, imersão e fluidez, que emprestam o nome ao first person shot.
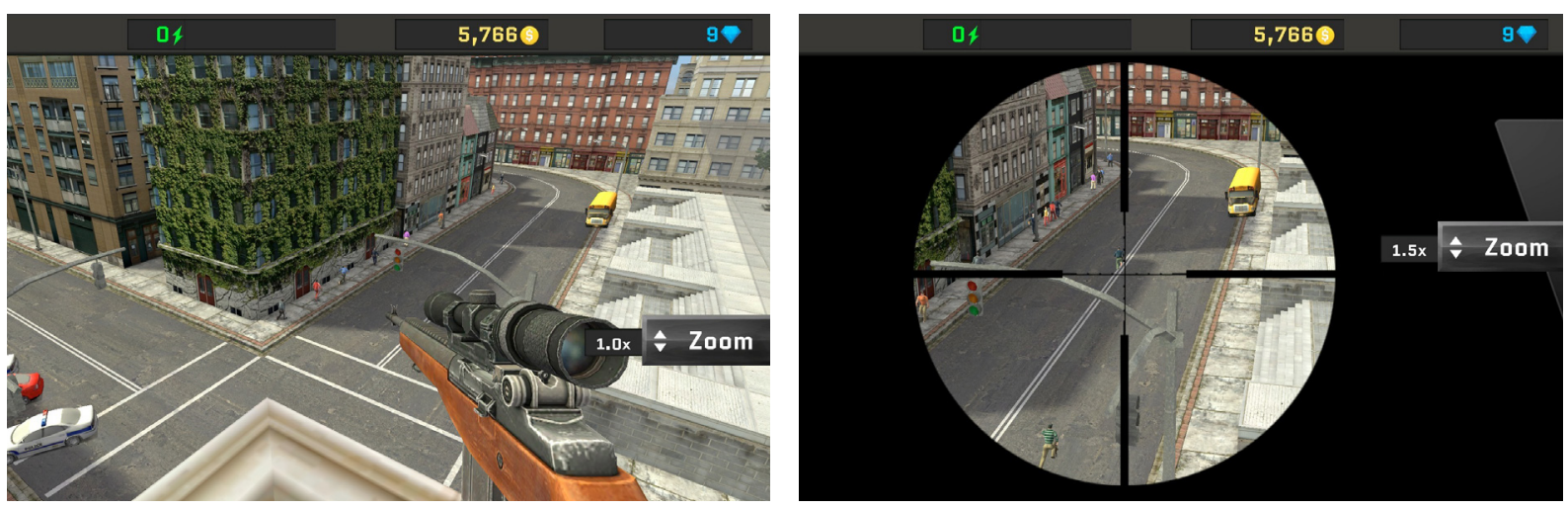

Figuras 29 e 30. Imagens de um jogo first person shooter, Sniper Ops.

Estes equipamentos e inovações, retrabalhados em contextos de significação deslocados de suas plataformas e com propósitos específicos diversos, constituiriam esta figura híbrida que entremeia diferentes dispositivos e funções.

Esta figura implica a existência de uma instância no universo diegético, incorporada em sua vasta rede de relações com seus objetos e sujeitos, que marca uma posição intencional do sujeito da percepção, podendo ou não ser correspondida por estes objetos e sujeitos outros do mesmo universo fílmico. A câmera torna-se um centro para o qual converge a realidade do filme, uma percepção subjetiva, um olhar mediado, pessoal e maquínico, automático e sensorial, detentor de um estatuto híbrido derivado do intercâmbio tecnológico e estilístico de mídias.

Para Eugeni, o ponto de vista subjetivo tradicional do cinema, a câmera subjetiva, devedora de seus pressupostos gramaticais narrativos, não pode perdurar em imagem por muito tempo no filme. O first person shot, ao contrário, escapa dessa submissão sintática e pode durar até mesmo o tempo integral do material filmado. O ponto que diferencia a figura da câmera subjetiva da figura do first person shot, segundo Eugeni, é o estatuto híbrido da segunda, que oscila constantemente entre um pólo subjetivo antropomórfico e outro pólo objetivo maquínico.

O POV subjetivo baseia-se na distinção entre o sujeito que observa de dentro do universo diegético e o objeto percebido. O first person shot apresenta polaridade entre sua atribuição a sujeitos percipientes diegéticos e ao aparelho de filmagem intradiegético, mas revela-se ambíguo ou os torna indiscerníveis. Este hibridismo cria a identidade entre a visão da personagens e a câmera que a possibilita, o que Eugeni denomina body sensor. Este agente híbrido empresta 
suas qualidades perceptuais, práticas, emocionais, sensório-motoras à constituição dinâmica da encenação do mundo operada pelo first person shot. O body sensor possibilita, segundo ele, dentro da diegese, quatro tipos de configurações intercambiáveis para a tomada em primeira pessoa:

- Subjetiva: antropomorfismo e reciprocidade presencial no universo diegético. Ex.: ponto de vista subjetivo, câmera subjetiva

- Protética: natureza de objeto inserido no universo diegético, manipulável intencionalmente por sujeitos ou objetos diegéticos e organizador da percepção. Ex.: câmera intradiegética.

- Escritural: antropomorfismo sem reciprocidade perceptiva junto aos sujeitos da diegese. Ex.: A câmera na mão ou em steadicam criando ênfase emocional em sequências de ação, mas sem implicar o cameraman como um personagem na diegese.

- Panóptica: natureza de objeto fisicamente presente e localizado no universo diegético que age sem a consciência das personagens ou sem a presença de um operador. Ex.: câmeras de vigilância, câmeras escondidas ou instaladas.

Para Eugeni, o first person shot é tanto uma figura de estilo quanto uma figura de pensamento. Enquanto figura estilística,"resulta de uma transformação radical do ponto de vista clássico ou da câmera subjetiva inserida na paisagem da mídia contemporânea"71, e detêm, por um lado, um caráter hibrido resultante dos adventos do steadicam, do videogame, microcâmeras e outras inovações tecnológicas, e por outro lado, é um corpo perceptivo e experiencial que ele denomina body sensor.

O first person shot para Eugeni está em contínua relação de dis-posição e des-locamento (dis-posed e dis-located) espacial e se vincula a teorias da mente inspiradas pela fenomenologia cognitiva que descrevem o sujeito como agente dinâmico em uma narrativa de negociação de si em constante transformação.

Quando, para além da transformação analógica da imagem-câmera, a generatividade digital simula ou integra organismo e máquina, o campo de visão e o ponto de vista tornam-se tela e pixel, superfície de inscrição de dados visuais, interface de controle e mediação da relação com o mundo, e não mais simplesmente janela ou aparelho óptico ilusionista.

71 EUGENI, R. First person shot. Technology and new forms of subjectivity in post-cinema landscape. In: academia.edu Disponível em: $<$ https://unicatt.academia.edu/ruggeroeugeni>, 2015. 


\section{1. Hardcore Henry}

A interpelação direta à câmera e ao espectador (que coincide com o sujeito da câmera subjetiva) estabelece as premissas da configuração que o filme vai assumir, isto é, a câmera subjetiva, neste momento, e o que virá adiante, ofirst person shot. Logo nas primeiras imagens do prólogo do filme, olhares e mesmo a interpelação falada são dirigidas ao protagonista-câmera.
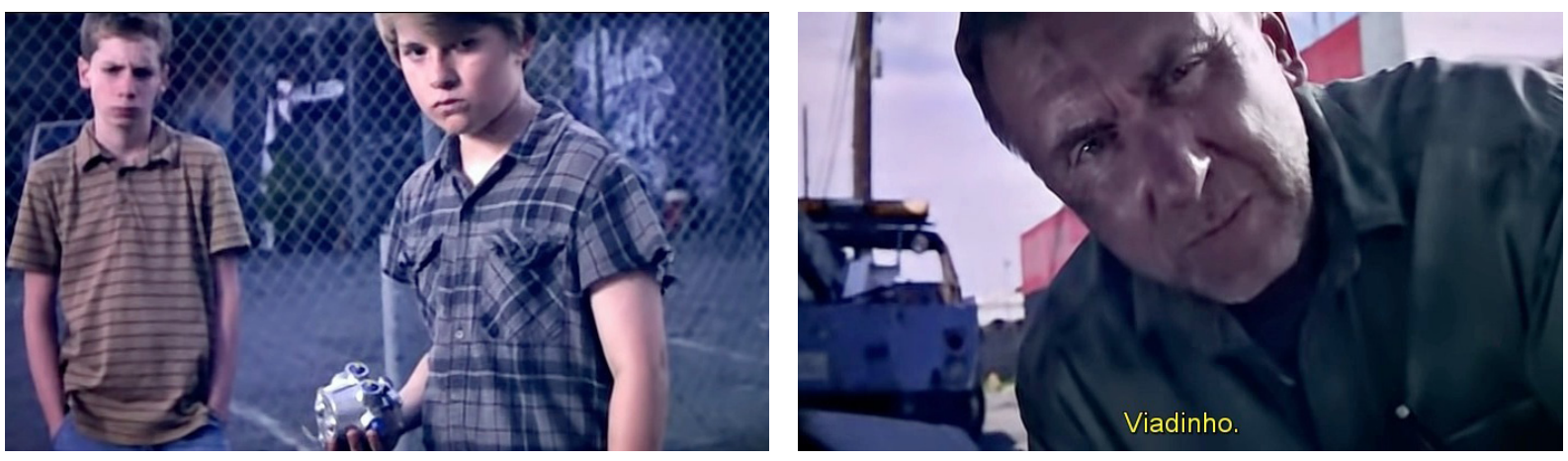

Figuras 31 e 32. Interpelação direta à câmera no prólogo de Hardcore Henry.

Se Ruggero Eugeni está certo em definir o first person shot por seu estatuto híbrido entre máquina e homem, por sua independência da relação campo/contracampo, e por sua duração ilimitada, Hardcore Henry parece ajustar-se perfeitamente a essas condições. Mais do que isso, se o first person shot é a configuração por excelência derivada dos jogos de tiro em primeira pessoa, o paralelo se completa: Hardcore Henry só carece da interatividade proporcionada por este tipo de videogame.

Fazem parte do ponto de vista deste filme todas as características antropomórficas já apontadas anteriormente. Mas as características deste sujeito extrapolam as mais comumente associadas ao POV subjetivo, já que ele é um super-humano. Henry é um andróide, quase totalmente reconstruído a partir de uma condição terminal, assim como foi o agente Murphy ao se tornar Robocop. Henry perdeu os olhos, uma perna, um antebraço, alem de ter a cabeça perfurada e esmagada. Mas, diferentemente do Robocop, Henry não teve tempo de ser testado, e já se colocou em ação. Diversos ajustes são feitos durante a própria fuga e perseguição que empreende, praticamente num só fôlego, durante o filme inteiro.

Se o prólogo caracteriza um flashback de cunho psicológico, o filme se pauta por uma ação em tempo presente, cujo caráter de ação quase sem pausas inviabiliza mudanças na temporalidade diegética mas, por outro lado, não impede cortes e pequenas elipses. Apesar disso, existem no filme sequências de rememorações subjetivas, sempre dinâmicas, que funcionam por contraste de conteúdo de imagem com a situação atual do personagem. 
A conjunção do ponto de vista em primeira pessoa e o frenesi da ação do filme implicam para a imagem uma série de aberrações de movimento, muitas vezes desconcertantes. Quedas, impactos, movimentos bruscos, deslocamentos velozes, ao mesmo tempo que fazem a graça deste tipo de filme, requerem do espectador um contínuo ajuste perceptivo para situar-se espacialmente. Isto permite cortes muito dinâmicos e trucagens, que contribuem para os efeitos especiais e para o ritmo do filme.

Uma característica que diferencia o ponto de vista deste filme da câmera subjetiva tradicional, e que permite ajustá-lo ao conceito do first person shot, é a intervenção na imagem, ocasionalmente, de rápidos dropouts, que atestam o caráter maquínico desta visão subjetiva. Dropouts são falhas na definição da imagem de câmeras digitais e magnéticas, ocasionados por diversos fatores, como presença de sujeira, danos no sensor, nos suportes, tais como discos rígidos, fitas, cartões de memória, etc.

A presença destas falhas digitais ${ }^{72}$ ocasionais na imagem, que tornam consciente para o espectador que uma máquina, sujeita a falhas, media sua relação com a imagem visada, constituindo-se literalmente um elemento de opacidade. A visão de Henry é a de uma câmera (seriam duas na verdade, uma para cada olho) e os dropouts servem para lembrar o espectador dessa condição.

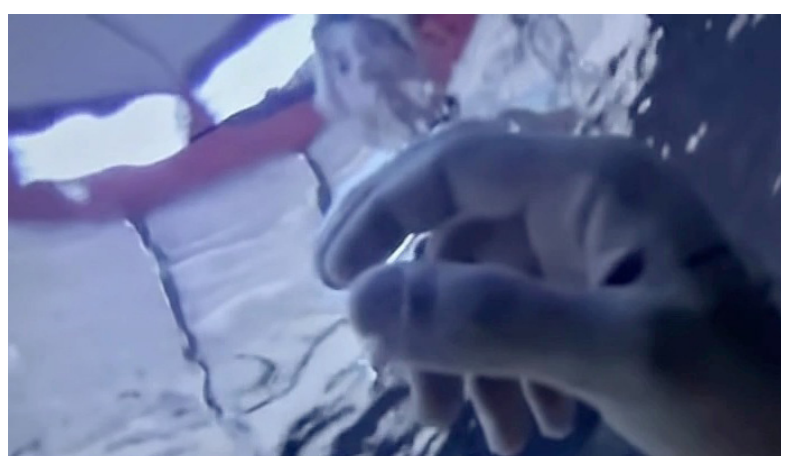

Figura 33. Hardcore Henry e a espacialidade do first person shot.

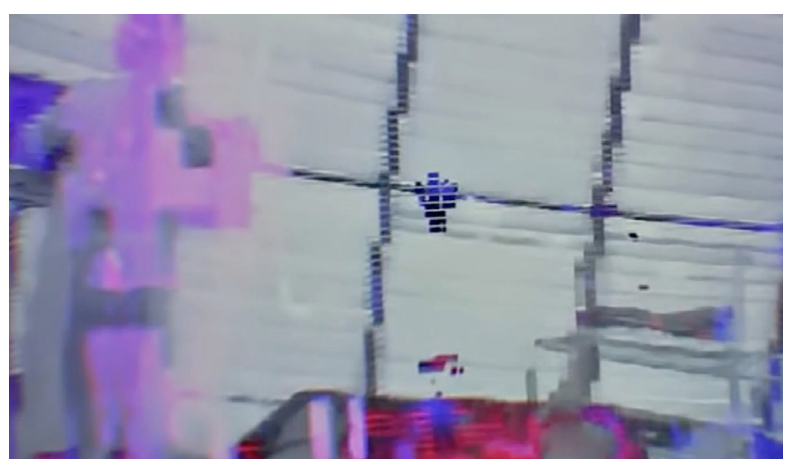

Figura 34. Dropout na visão de Henry.
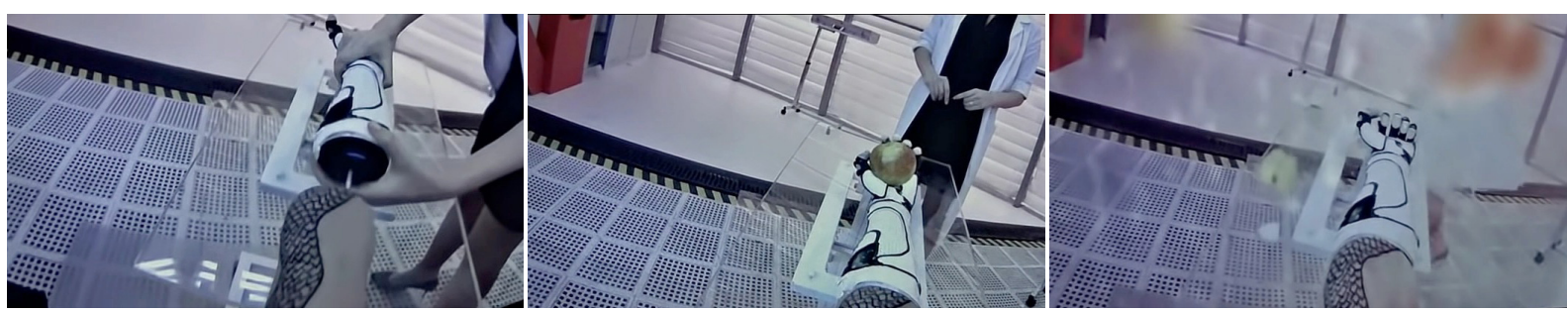

Figura 35. Sequência da implantação do braço mecânico e demonstração de força em Hardcore Henry.

72 Este recurso é muito usado também nos filmes que utilizam câmeras intradiegéticas, com a mesma função, além de outras funções associadas, principalmente em filmes de terror, para aumentar a tensão e o suspense. É praticamente um recurso estilístico presente na maioria dos filmes de terror da nova geração. 
Na sequência do assalto às tropas do vilão Akan em um conjunto de edifícios abandonados, a semelhança com jogos de tiro fica evidente. O suspense advindo da movimentação por um território desconhecido, onde o inimigo espreita e aparece a qualquer momento, faz da visão em primeira pessoa um recurso muito eficaz para a manutenção da tensão da ação. Torna também espetacular a ação do first person shooter, por seus movimentos, emboscadas, tiros certeiros, desvios, etc. A imagem, tão comum nestes jogos, de uma arma sendo apontada para a frente, bem como a troca de armas, sua utilização, mira, disparos, arremesso de granadas, é utilizada à exaustão. Nem é preciso mencionar a carnificina resultante destas ações: corpos explodindo, sangue espirrando, corpos mutilados, etc, todos os clichês dos filmes que se voltam para a violência espetacularizada, e proporcionam o delírio visual dos amantes deste gênero.

Os méritos de Hardcore Henry na superação das dificuldades da manutenção sistemática do ponto de vista subjetivo e da fluência da narrativa e da movimentação tornam-no um caso paradigmático do emprego de câmeras acopladas ao corpo do cinegrafista, do ensaio de atores e efeitos visuais de ação, em uma coreografia da violência, do ponto de vista em primeira pessoa. A eficácia na simulação dos videogames de first person shooter é mantida por toda a frenética duração do filme.
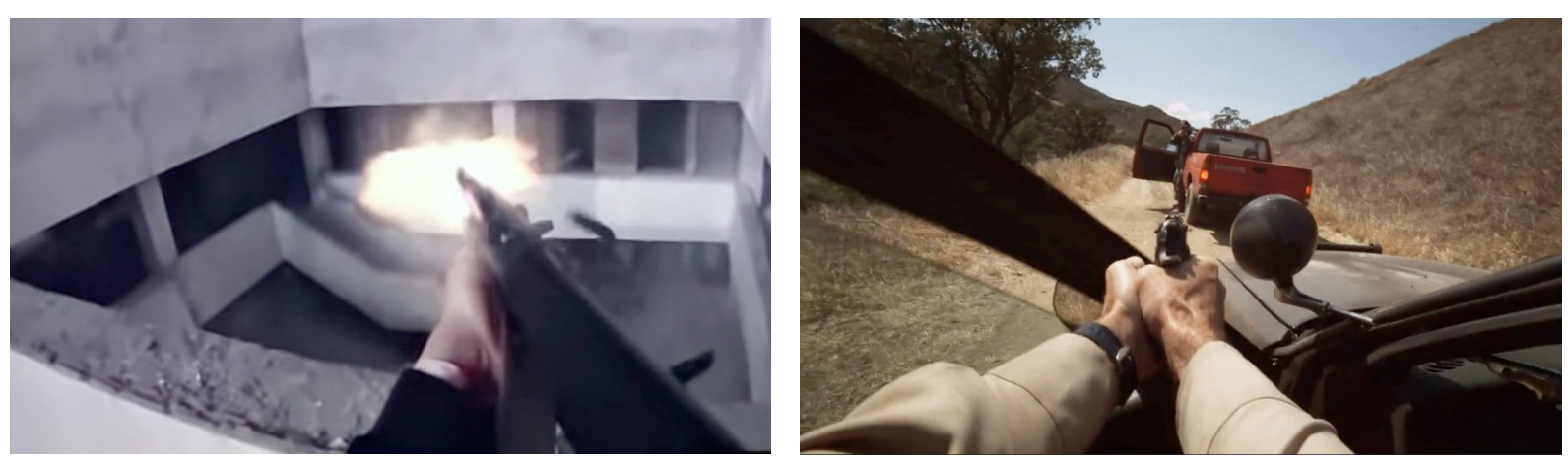

Figuras 36 e 37. First person shot em Hardcore Henry e em Random Stop.

Um pequeno curta-metragem de 2014 intitulado Random Stop é também sintomático da vinculação do uso do ponto de vista subjetivo à herança dos games de tiro em primeira pessoa. O protagonista-câmera dessa vez é um policial, que durante seu expediente de trabalho em uma auto-estrada, obriga um carro em alta velocidade a parar no acostamento. O motorista do carro infrator oferece resistência ao comando do policial, mantendo um comportamento agressivo. Eles acabam trocando tiros, e o policial é atingido, e executado a sangue frio pelo motorista infrator.

Baseado no fato real que ocorreu em 1998 em Laurens, na Carolina do Sul, o curta é um exercício do ponto de vista subjetivo, que dura aproximadamente sete minutos. Para fazer 
o espectador compactuar com o policial, além do emprego do ponto de vista, o filme se vale de recursos afetivos na caracterização do protagonista, como a utilização de uma chamada telefônica para sua esposa, acompanhada pela manipulação simultânea de fotos de sua família. Este background funciona como lastro emocional que emoldura sua morte na execução de seu ofício. Inserções gravadas em chromakey serviram para refletir o protagonista em superfícies polidas tais como vidros e carroceria da viatura, que além de reforçar o aspecto realista da tomada, contribuem para o espelhamento do sujeito-da-câmera, tão necessário para o efeito de identificação do espectador com aquele.

No making off do curta, o diretor de fotografia e cinegrafista Justin Perkinson declarou que optou pela forma do first person POV por causa de sua emergência estilística relativamente nova e derivada dos videogames. Ele se valeu de uma câmera e um monitor acoplados em um capacete de motociclista, que é um recurso bastante utilizado pra esta finalidade. Um computador e outro visor nas costas do cinegrafista completavam o aparato de gravação de imagens, e serviam como referência para o ator que fazia a voz do policial, situado atrás de Justin. Este projeto se inspirou no filme End of Watch, que também tematiza a rotina policial, e que fez uso de microcâmeras em sua produção ${ }^{73}$.

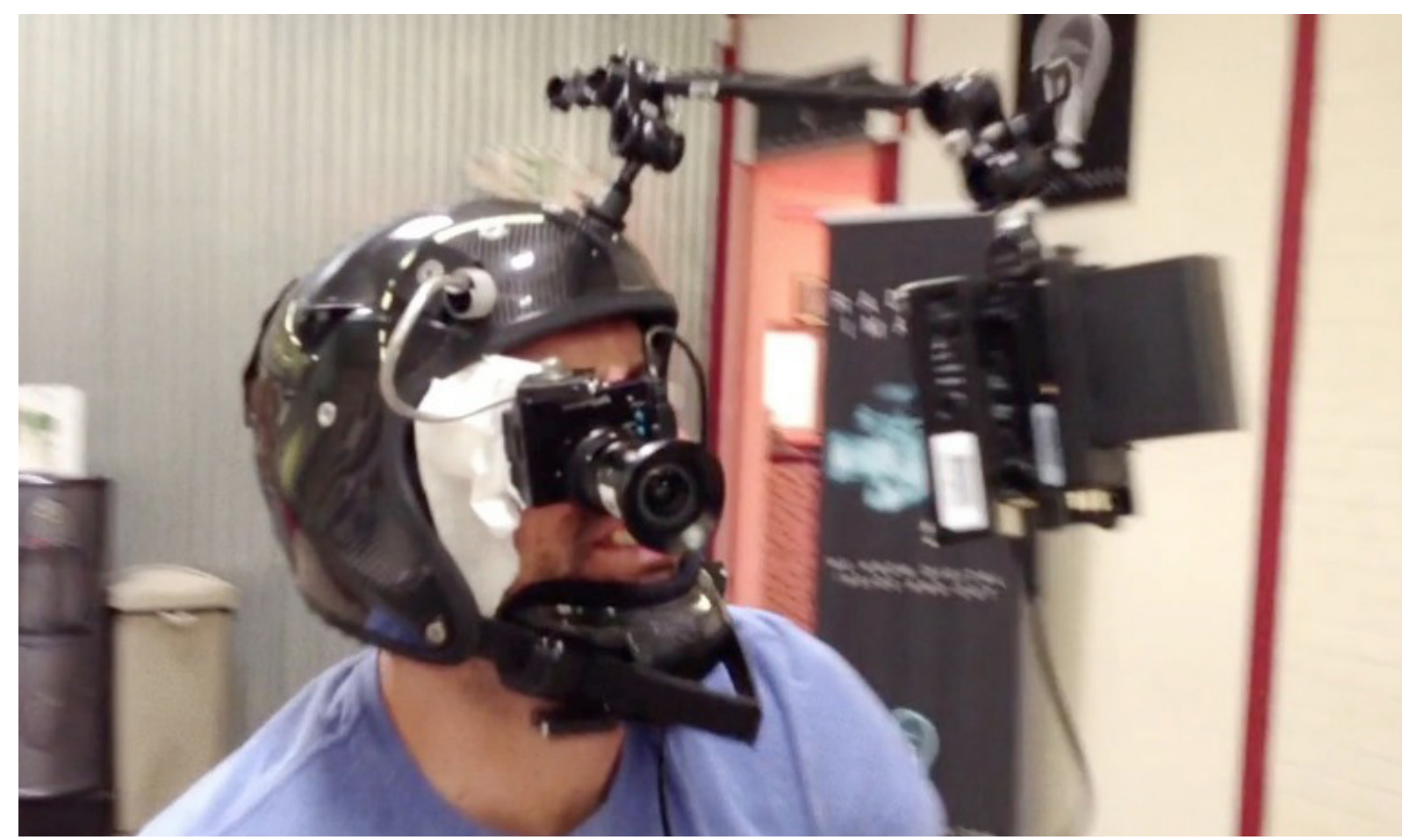

Figura 38. Aparato de captação do first person shot em Random Stop. 


\section{2. Câmera intradiegética}

O acesso popular aos dispositivos de captura e exibição e ao barateamento das técnicas de produção audiovisual interferem tanto no regime de produção e de exibição, quanto no estilo e projeto de cada filme. A propagação e difusão do acesso aos aparelhos, bem como as tecnologias de manipulação do material audiovisual, permitem a renovação e transformação das perspectivas discursivas, dos pontos de vista, onde a subjetividade exerce importante papel, tanto nos registros que buscam um lastro de veracidade documental quanto nas construções ficcionais, narrativas ou não-narrativas. A facilidade na obtenção de material audiovisual original, apesar de proporcionar muitas vezes qualidade duvidosa, permite a criatividade e a invenção. Os meios de divulgação também fazem a diferença. A internet, mostras, festivais, museus, dispositivos móveis, home theaters, etc., multiplicam os canais de acesso a obras audiovisuais, estimulando e dando visibilidade a essa produção.

O banco de dados que a internet proporciona, além da divulgação, do armazenamento e do acesso às obras, constitui um manancial de recursos para a produção de novas obras e novas formas. A cultura remix, apropriações e recomposições com found footage ou material alheio, eventos em tempo real, estão cada vez mais presentes no cotidiano.

Os filmes que simulam of found footage, filmes que compartilham um olhar mediado por dispositivos de captura variados, mobilizam um estatuto documental na criação ficcional. Assim também fazem os mockumentaries, que atravessam gêneros variados e dispõem novos dados ao problema do ponto de vista. Tratam-se de falsos "found footage", pois simulam material de arquivo encontrado e trabalhado posteriormente. Um falso documentário se vale da crença na positividade dos fatos narrados para, a partir disso, construir os fatos ficcionais. O testemunho indicial proporcionado pelo material encontrado, fitas perdidas e depois redescobertas, atesta a veracidade de seu conteúdo em relação aos fatos ocorridos.

A leitura documentarizante dessas imagens aponta para o sujeito-da-câmera, esta instância vidente que participa e compartilha esse olhar que ousaria chamar de meu, por empréstimo. A enunciação se evidencia pelo relevo que o aparato de captura adquire na narração, frequentemente à serviço da veracidade do narrado. A finalidade dessa construção do sujeito procura legitimar um testemunho indicial de presença física e real no decorrer do acontecimento, bem como a partilha da responsabilidade de sua ativa participação nele.

O discurso direto da personagem escamoteia tanto um autor quanto uma testemunha: agente da enunciação fílmica, faz convergir o tempo da vivência com o tempo da narração, refazendo um acontecimento, um evento fílmico auto-reflexivo. 
Entretanto, outros fatores vêm minar esse fundamento: a manutenção do regime de filmagem em condições irreais ou mesmo "impossíveis"; a homogeneidade do estilo em condições desfavoráveis; o apelo à identificação contrastando com a impessoalidade dos pontos de vista, o embodiment das instâncias paralelo à comutação das perspectivas, etc.

Na maioria dos filmes que inserem as câmeras em suas tramas para tudo registrar, sobrepõem-se a verdade indicial atribuída à câmera profílmica e o testemunho da presença de um "sujeito-da-câmera", para criar o efeito de real. O que não impede que um efeito paradoxal da enunciação desrealize a si mesma ao registrar tudo a qualquer custo.

A câmera operada pelo personagem, também utilizada sistematicamente como ponto de vista dominante da encenação, uma câmera intra-diegética, faz surgir um personagem-encenador que mimetiza e camufla, por sua vez, o trabalho do cineasta. O estatuto de ficção precisa se recobrir de realidade para dar credibilidade ao relato visual mediado pelo personagem, e dependerá da múltipla identificação: olhar do espectador/olhar do personagem/dispositivo de captura. Filmes como Redacted, de Brian de Palma, ou A Bruxa de Blair, de Daniel Myrick and Eduardo Sanchez (1999), ligados respectivamente aos gêneros da guerra e do horror sobrenatural, são falsos documentários relacionados aos modos documentais observativo, participativo e reflexivo definidos por Bill Nichols ${ }^{74}$.

Desde A Bruxa de Blair a visão da câmera é associada a seu operador, um personagem que documenta o acontecimento: uma busca, uma aventura, uma expedição, seja o que for, uma câmera que opera esta fusão do subjetivo e do maquínico, um dispositivo subjetivo, a câmera prótese do corpo, a enunciadora da pessoa da personagem, dêitico e índice. Antes porém, com Holocausto Canibal, a câmera já estava lá como testemunha, como prova do isso foi que Barthes atribuía à fotografia. Tanto que o diretor sofreu investigação posterior para apurar o realismo da matança de animais exibida pelo filme. Mas a associação tão íntima da câmera e do personagem carecia da sistematização que o first person shot viria a ter.

Na câmera na mão em Holocausto Canibal, o seu manejo denota o operador. Mas há um excesso de eficácia desse registro que minimiza o efeito de subjetividade, e funda também uma distância entre o operador e o universo diegético. O caráter documentarizante do registro, ao mesmo tempo que atesta a presença do operador na diegese, no acontecimento filmado, é tão auto-referente e eficiente, que minimiza qualquer efeito de subjetividade, com toda a idiossincrasia que esta possa estar investida. A marca da inclusão do cameraman no registro material 
deixado pelos excursionistas desaparecidos vale pelo testemunho documental de suas ações abjetas e irresponsáveis, mas não é prenhe de características individualizantes de personagem que opera esta câmera.

Em Holocausto Canibal, a rigor, o ponto de vista é o da câmera de filmagem, a câmera intradiegética. Mas esta difere de uma subjetiva indireta livre principalmente pelo fato de não possuir a liberdade de escapar das malhas da eficiência narrativa. Isto aciona o reverso da intenção do filme, seu realismo cru, e estimula a leitura ficcionalizante ou fictivizante, como propõe Roger Odin. Ou seja, é a leitura ficcionalizante que adquire relevo e dilui o sujeito-da-câmera na eficiência narrativa documental.

O cameraman, de potencial vítima intradiegética, distancia-se do espaço profílmico, escondendo-se, quase invulnerável, em uma instância atrás da câmera. Ele passa desapercebido pelos retratados por ele, e sonega sua participação efetiva no acontecimento. Isso confere à sua câmera apenas um papel estilístico, remetendo sua participação ao nível de discurso metadiegético.

Esse efeito é evidente na figura escritural proposta por Eugeni. A configuração escritural se define pela ausência de reciprocidade perceptiva dos personagens internos à diegese em relação à presença da câmera.

O ponto de vista subjetivo tem sido cada vez mais explorado na contemporaneidade, quebrando dogmas e preconceitos assentados pelas teorias e críticas, mas também, por outro lado, reiterando formas que acabam por desgastar-se e tornarem-se insípidas. O uso da câmera intradiegética pelos filmes de terror é um exemplo deste aspecto. A limitação que o ponto de vista subjetivo da câmera associada a seu operador impõe, se permite o suspense através do que sugere e não mostra, utilizando o extracampo e a mobilidade a seu favor, acaba por tornar-se um clichê extenuante, usado em demasia no filme, ou presente em uma série de filmes, utilizado com o mesmo efeito e propósito.
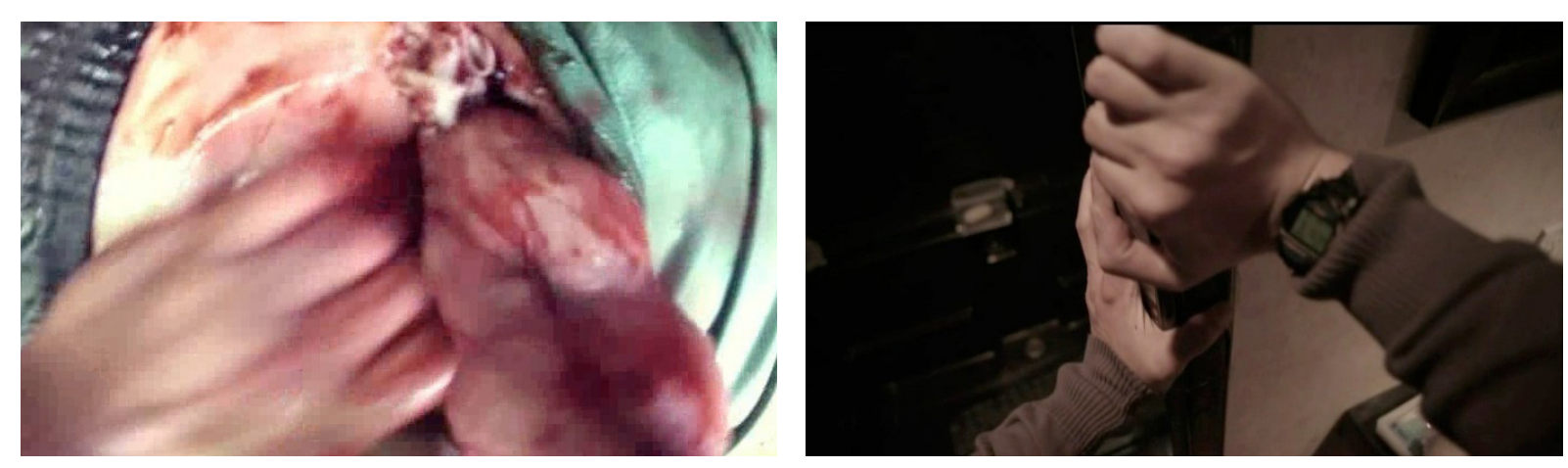

Figuras 39 e 40. V.H.S. 2: Câmera acoplada num capacete de ciclista, implantada no olho do personagem. 


\section{3. Megan is Missing}

O filme se apresenta como baseado em fatos reais, mas não fornece mais dados que possam contextualizá-lo ou relacioná-lo a um fato anterior. Parece mais um imperativo para a crença do espectador, onde a plausibilidade dos eventos apresentados deve coincidir com a disposição do espectador para crer em sua verossimilhança. Esta é quase uma regra nos filme que compilam registros encontrados: o fake found footage deve parecer real, e uma série de características presentes no material e procedimentos na forma de agenciá-lo consolidam uma estética presente na maioria desse filmes, como por exemplo o uso de handicams, o tremido do manuseio delas; o dropout digital, erro ou borrado na gravação, que afeta também o áudio; as inscrições em tela de filmagem, tais como data e hora de filmagem, indicações de que a câmera está gravando; entre outros.

Uma das principais características é o intuito de registrar o material para um fim justificado no filme. Assim, a realização de diários em vídeo, filmes pessoais, trabalhos escolares ou profissionais, ou mesmo uma pulsão injustificada de continuar filmando a qualquer custo estão presentes nestes filmes. O importante é estabelecer qualquer motivação para a coleta de imagens não parecer despropositada, por mais que muitas vezes essa desculpa se torne muito tênue em situações que fica difícil prosseguir filmando.

Este filme é até econômico na exibição dessas características, até porque é compilado com materiais de diversas fontes. Todas as imagens são criadas de modo a exibir características dos media a que foram "retiradas" mas de forma a generalizar sua identidade específica. Assim, por exemplo, teleconferências via celular ou via web, bem como os telejornais são fictícios. O filme Unfriended, diferentemente, exibe o nome, a interface e o ringtone característicos do Skype, por exemplo.
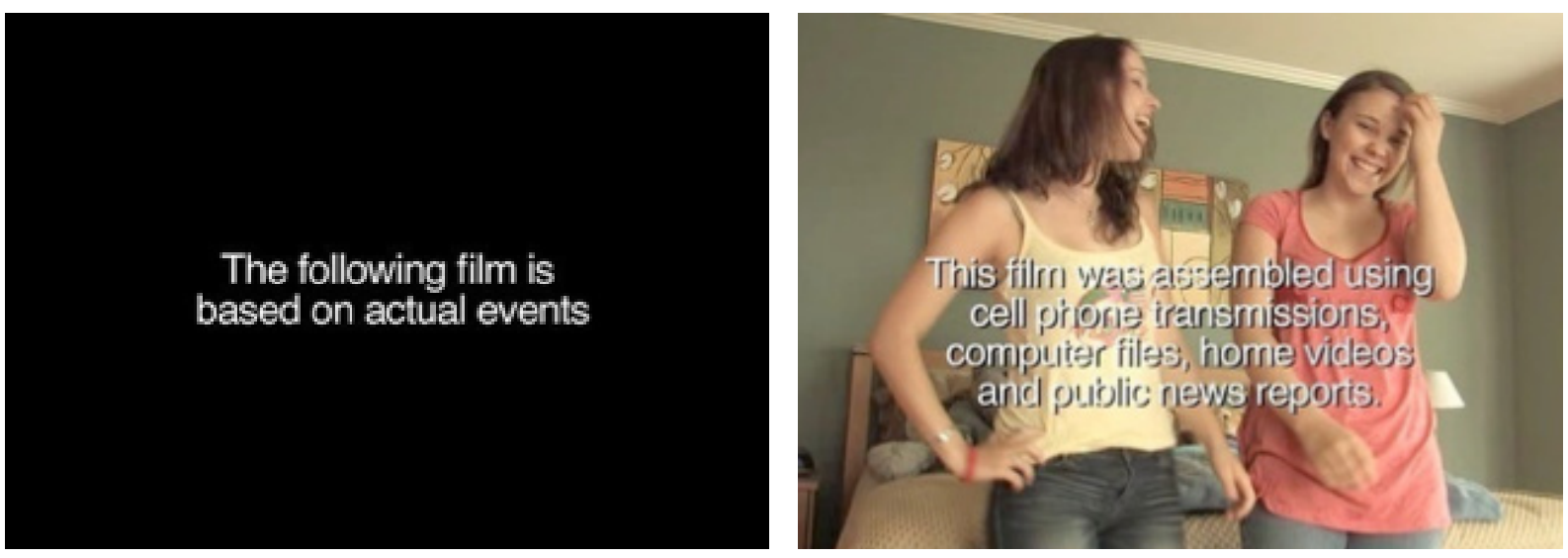

Figuras 41 e 42. Primeiras cartelas do filme Megan is Missing. 
Megan e Amy aparecem juntas na câmera que Amy ganhou de presente de seu pai. Já por seus cumprimentos e pela conversa entre as duas, Megan se julga uma mulher adulta enquanto Amy tem uma postura infantil.

Amy se sente um pouco ressentida quanto ao seu corpo e sua aparência, demonstra insegurança. Seu pai quer comemorar seu aniversário, mas ela rejeita como coisa de criança.

A experiência sexual é determinante no modo com elas se comportam. As amizades de Megan giram em torno de festas, drogas e sexo, enquanto Amy se sente bastante deslocada frente a isso. Ao convidar Amy para uma balada, Megan sente o preconceito de seus amigos em relação a Amy, que apresentam reserva quanto à presença dela na festa.

Sequência da festa: um cameraman amigo do anfitrião documenta o evento, onde Amy permanece à margem. A equipe de filmagem aparece em imagem, luz, áudio e a câmera é interpelada pelo mestre de cerimônias da festa, centro do interesse do registro. A câmera é sua ferramenta de exibição e promoção pessoal. Mas a edição das imagens aponta para a experiência de Amy e sua amizade com Megan, que lhe revela a sexualidade e a submissão velada que a acompanha suas relações sociais e sua inserção em um grupo. Um tom dramático cerca a personagem de Amy, que se sente desconfortável durante a festa e acaba por vomitar na cabeça de duas garotas que se beijam, atração da filmagem. Demonstra uma espécie de comentário escatológico sobre a festa, onde ela esboça uma revolta incipiente contra tal submissão no tratamento dado às garotas pelos rapazes da festa, jovens metidos a gangsters.
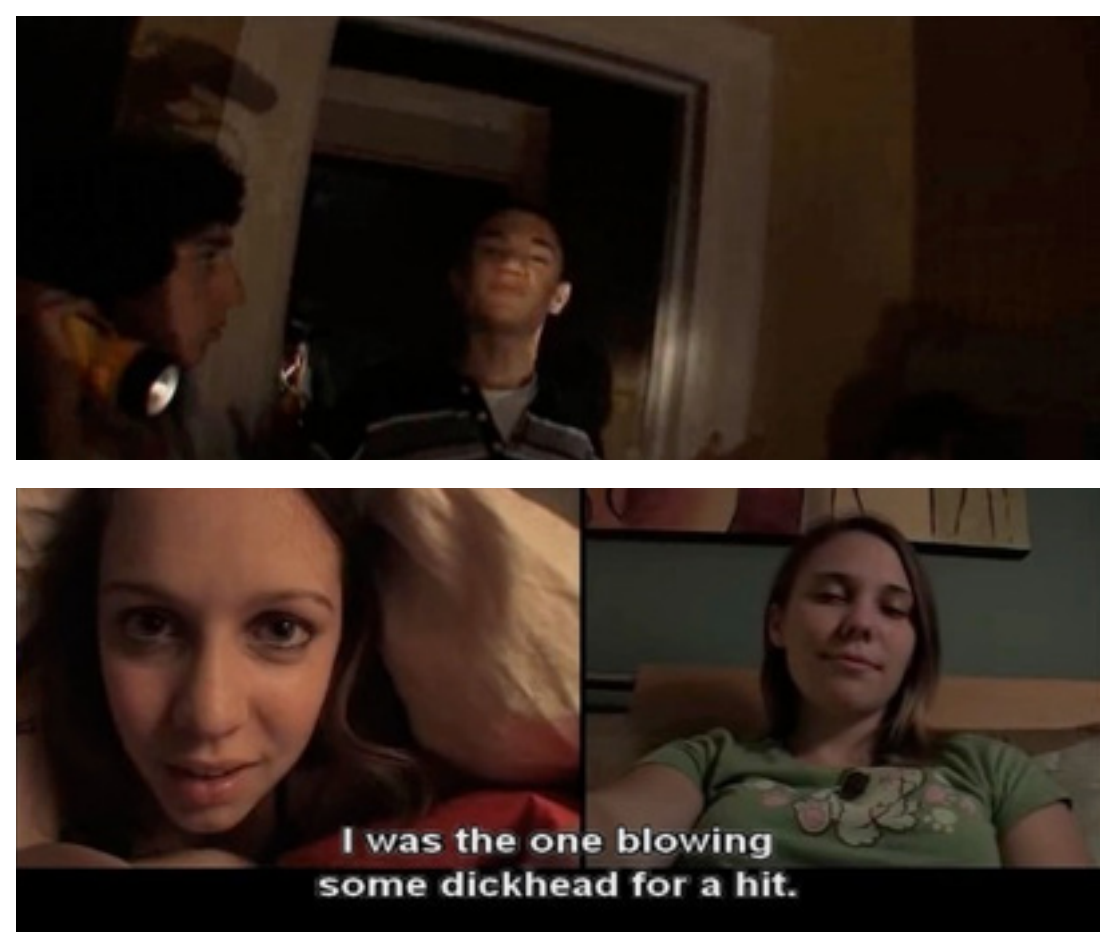

Figuras 43 e 44. Megan is Missing. Equipe de filmagem durante a festa. No dia seguinte, Megan e Amy conversam por videoconferência. 
A reserva de Amy indica sua cautela em se relacionar com o sexo oposto, a despeito da experiência e abordagem luxuriosa de Megan sobre o sexo e das investidas que ofendem o pudor de Amy. Apesar de apenas um ano de diferença de idade, a maturidade de Megan contrasta com a meninice de Amy. Suas conversas por teleconferência mostram suas relações com os pais: Amy é amada pelo pai, Megan só briga com a mãe. Reforçam também sua amizade e um desejo de Megan de fugir de casa com a amiga. Apesar de temperamentos opostos, ambas serão atraídas pelo sedutor anônimo.

Com a nova câmera de Amy presenteada por seu pai, Amy entrevista Megan, que revela seu problema familiar: pai ausente, abusos sofridos pelo padrasto, ressentimento pela mãe. Por seu turno, Amy revela que o pai é separado da mãe, visitando a filha nos feriados. Amy exibe ironia ao definir sua mãe como "tão boa mãe quanto corretora de imóveis".

Megan desculpa-se com a amiga alvejada por Amy na festa, e esta menciona um novo amigo que conheceu pela internet, um jovem chamado Josh, o Skatista, que é o perfil falso que o criminoso utiliza para acercar suas vítimas.

Megan trava diálogo com ele por videoconferência via web, embora nunca veja o seu rosto, com a desculpa dele de ter quebrado sua webcam. Quando Amy a visita em sua casa, ambas

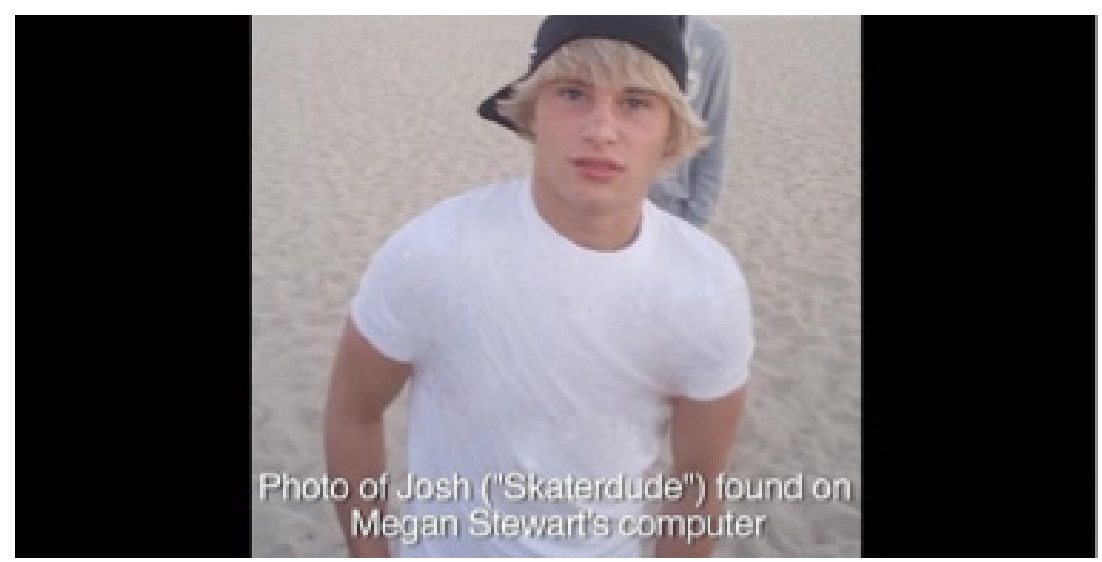

Figura 45. Megan is Missing. Foto falsa do assassino para atrair Megan.

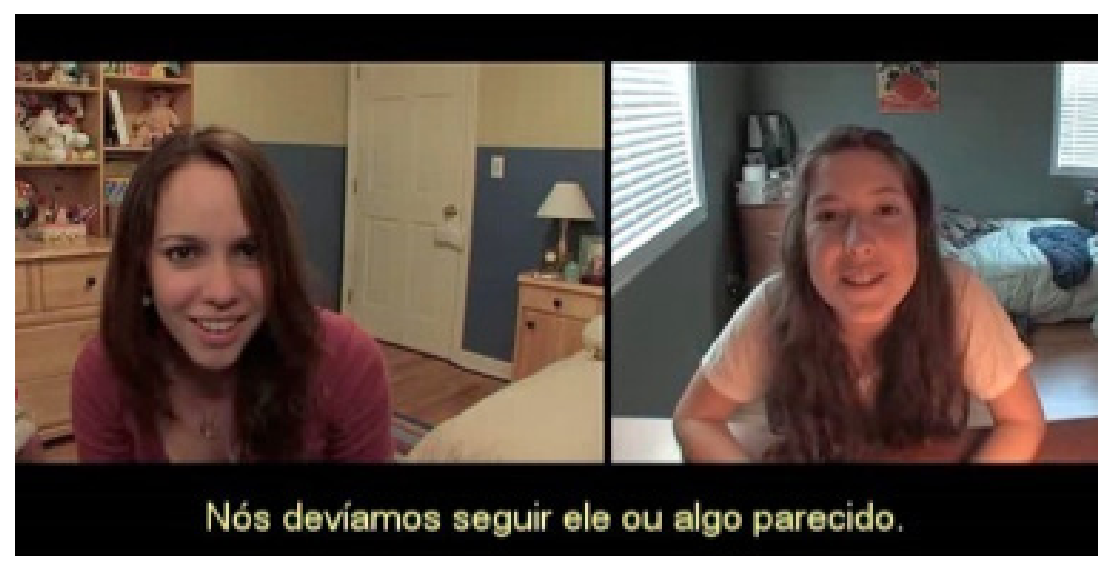

Figura 46. Megan is Missing. Teleconferência entre Megan e sua amiga a respeito de Josh, seu novo amigo virtual. 
conversam com Josh. Megan marca um encontro com ele atrás da lanchonete. Não volta desse encontro. Os jornais televisivos revelam uma filmagem de câmera de segurança posicionada atrás da lanchonete do encontro onde Megan é vista pela última vez sendo abordada por um homem, que a puxa pelo braço. É impossível identificá-lo pela filmagem, provavelmente este sabia da existência da câmera.

Amy retoma o diálogo com Josh após o incidente, e pergunta a ele se ele fez algo com ela ou sabe de seu paradeiro. Josh desconversa fazendo piada da inocência de Amy. Esta revela aos noticiários a relação que Megan estava mantendo com esse skatista que conheceu na internet. Amy faz de seu video-diário um veículo para investigar seu desaparecimento e relembrar sua amiga. Josh ameaça Amy, repreendendo-a por mencioná-lo às autoridades.

Em uma das filmagens de Amy, onde ela esconde seu ursinho de pelúcia favorito, debaixo de uma ponte em um parque, um vulto aparece atrás das árvores. Ele fica parado lá até o fim da tomada da câmera de Amy. Ao completarem 3 semanas do desaparecimento de Megan, Amy volta lá, e sua câmera registra um braço de homem que procura segurá-la. A explicação vem pelo telejornal: Amy também foi sequestrada, provavelmente pelo mesmo raptor.
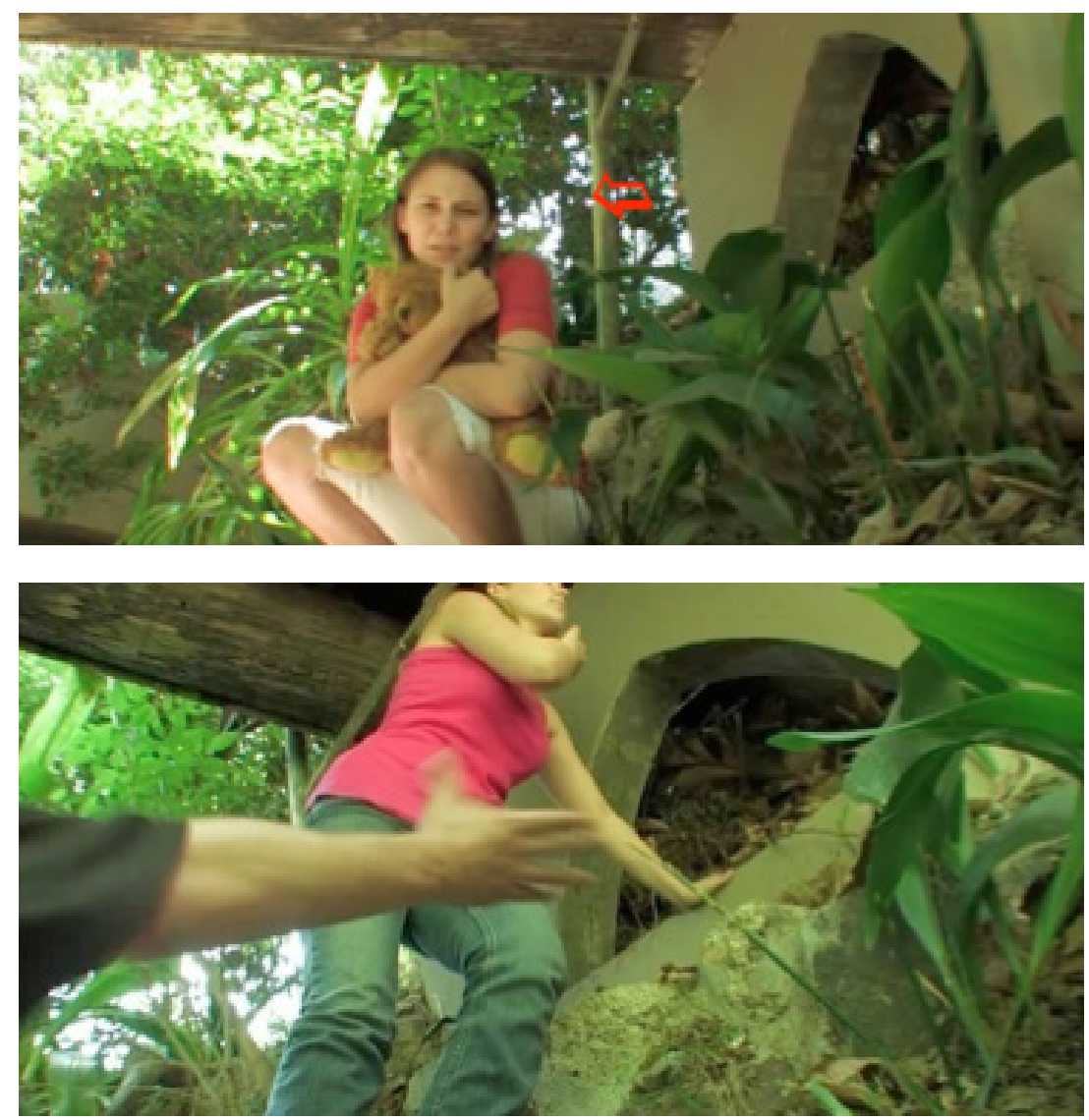

Figuras 47 e 48. Megan is Missing. Indicação minha do vulto do raptor atrás das folhagens e momento do ataque a Amy. POV da handicam de Amy, de dias diferentes. 
É curioso que o raptor nunca apareça completamente nas diversas oportunidades em que agiu, onde manteve posicionamento estratégico perante as câmeras. Nesta última, a imagem congela no gesto dele, privando o espectador da reação de Amy. Sua câmera de vídeo foi encontrada no parque, deixada pelo criminoso, contendo uma filmagem de mais de 20 min feita por ele, mostrando o suplício de Amy em seu cativeiro.

Se o filme até aqui procurava alertar a sociedade para os perigos de gente mal intencionada na internet, seu tom muda para uma descrição cruel e violenta do procedimento com as vítimas: Amy é estuprada, mantida acorrentada somente com a roupa de baixo, e o raptor mostra para ela o cadáver de sua amiga, escondido em um barril de plástico. Ele cava um buraco, apesar dos protestos e desesperadas promessas de Amy de amor e submissão. Amy sabe que o criminoso quer submetê-la à sua vontade, e ela roga a ele que a liberte, dizendo amá-lo, e insistindo em chamá-lo de Josh. Parece um blefe da parte dela, motivado pelo desespero, ou sua inocência em tentar mudar a atitude de seu algoz, e o filme explora a ambiguidade dramática dela implorando o amor dele enquanto ele friamente enterra o barril com ela dentro, cujos gritos vão sendo silenciados a cada punhado de terra acrescentado.

O epílogo mantêm a crueldade e ironia, ao mostrar as duas conversando sobre o futuro e sobre encontrar o cara certo para elas, como o fazem as meninas adolescentes, contrastando com a atitude de objetificação sexual das mulheres tomada pelos homens.

\section{4. Symbiopsychotaxiplasm}

Symbiopsychotaxiplasm - Take One foi produzido e dirigido por William Greaves em 1968 e ficou sem lançamento por mais de 20 anos até que em 1991 foi redescoberto numa retrospectiva do diretor pelo Brooklyn Museum.

O filme é uma espécie de documentário experimental sobre a filmagem de um núcleo dramático entitulado “Over the Cliff”, onde trabalham paralelamente três equipes de filmagem, com três ou possivelmente quatro câmeras: uma equipe voltada à encenação do drama, com uma câmera na mão do diretor, e outra com seu cinegrafista, que algumas vezes se dividem em cada um dos atores, marido e mulher; uma documentando a equipe de filmagem; e uma terceira registrando tudo o que pode, atores, diretor, a primeira equipe, a segunda equipe, bastidores, conversas e comentários dentro e fora do set de filmagens, observadores, etc. Assim, são criadas duas instâncias narrativas, uma dentro da diegese do filme, outra fazendo seu making-off, simultaneamente. 
Fundamentado na estética do cinéma vérité que se pauta pela eliminação das barreiras técnicas (grandes equipes, uso de cenários em estúdio, câmeras em tripés e traquitanas, parque de luz, figurino, maquiagem, etc.), de procedimento (roteirização, atuação, direção), e estruturais (gêneros tradicionais de melodrama, comédia, ocultação do dispositivo), que distanciam o assunto do público espectador.

Para isso, a encenação da discussão de casal se torna um pano de fundo onde a realização de uma rebelião em torno do filme se torna o motivo principal. Rebelião contra a forma tradicional de se filmar, nos idos rebeldes de 1968.

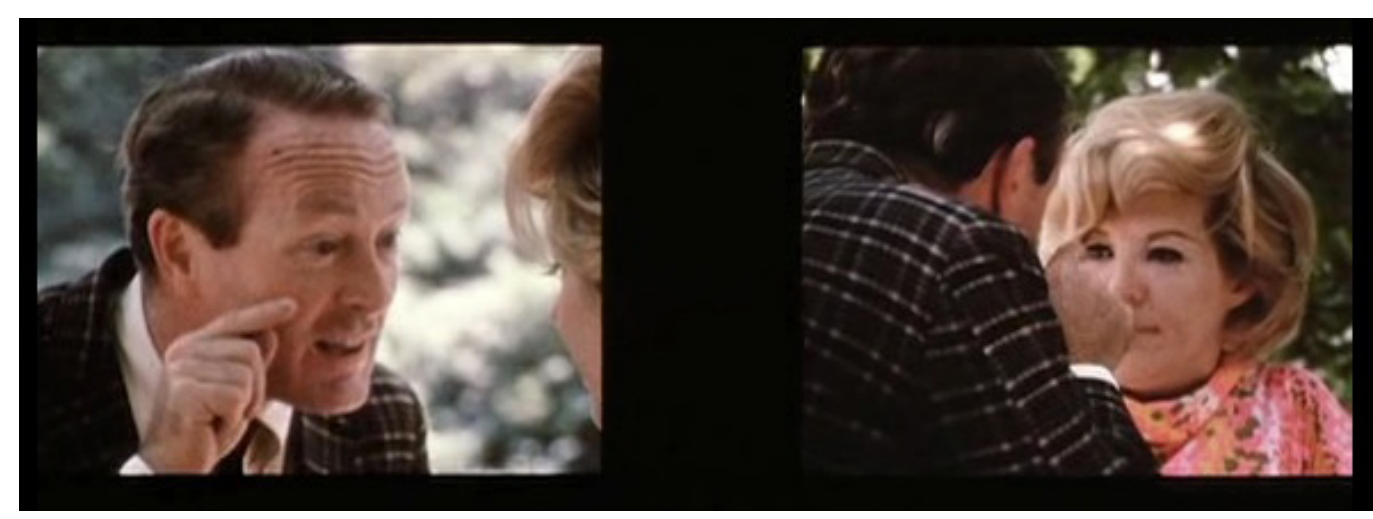

Figura 49. Campo e contra-campo simultâneos por divisão de tela no filme Symbiopsychotaxiplasm.

O filme recorre à divisão em duas ou três telas dentro do quadro, por vezes, para revelar a simultaneidade dos pontos de vista múltiplos. O drama diegético versa sobre um casal em crise discutindo a relação, e é representado por cinco pares de atores diferentes, contribuindo para o aspecto geral de sobrecarga e indecisão que compõe o filme. Atores e equipe são flagrados em suas discussões sobre o andamento conturbado do filme, a desorientação do trabalho de direção, a banalidade dos diálogos encenados, e a equipe passa noites em claro discutindo a possibilidade de salvar o filme. Todo este material documental sobre o filme é alternado com sequências do trabalho no set, obsessivamente retomado, que o diretor pretende que se torne um longo plano-sequência ideal.

Longos planos-sequência, tremidas de câmera, perdas de foco, variações de exposição fotográfica da película, comentários metalinguísticos, pontas pretas de negativo, apreciações e fofocas de bastidores, etc., tudo isso é a matéria de construção deste filme, um filme reflexivo sobre o fazer fílmico no que tem de promessa e de frustração, de revelado e oculto, no que ele tem de planejado e de improvisado. O jazz da trilha sonora reforça essa vivacidade lúdica do improviso. 
Revela a feitura de um filme como um lugar de tensão criativa entre uma visão individual e o empreendimento coletivo. Se o diretor Bill Greaves aparece inicialmente como indeciso e levado pelos acontecimentos e situações que fogem à seu controle, depois percebemos que ele não é tão ingênuo quanto parece, e que talvez seja o grande condutor desse desvio todo. Mas e se Greaves decidir incluir tudo o que especulam sobre ele no filme? "Seria a maior decepção de todos os tempos" diz alguém. Será meramente dele a autoria do filme? Mas se o filme é da autoria de todos os envolvidos, existiria um projeto original? Como controlar a improvisação? "Não me levem a sério", diz o diretor no início do filme.

O tonos crescente da desconfiança da equipe em relação ao diretor torna-o alvo de crítica: uma equipe multi-étnica liderada (incompetentemente, dirão alguns) por um afro-americano, encarnando as contradições de um modo convencional de produção fílmica, tematizando a homossexualidade, o aborto, a guerra do Vietnã (você está matando meus bebês um após o outro), tornando o processo permeável às pessoas.

Willian Greaves procura em Symbiopsychotaxiplasm retratar a sexualidade implicada na relação entre seres humanos. A sequência de abertura com os créditos iniciais do filme retrata um ciclo de vida onde as pessoas se conhecem, se relacionam (sexualmente), geram filhos que crescem e se relacionam e se reproduzem e perfazem novos ciclos. Através de diversos visitantes do Central Park, Greaves encadeia estas atrações, que ditam o subtexto da trama do filme que estão a fazer, que a trilha sonora tensiona ao conjugar o jazz à microfonia.

Como num relacionamento entre seres humanos, por um lado existe o planejamento de elaboração conjunta e de outro o lado fortuito de como isso acaba acontecendo. Existe o investimento irracional do desejo, a ilusão da objetividade, do controle, da estabilidade ao mesmo tempo em que a vida desfia e desfila sua trama complexa de produção e reprodução dela mesma.

A sequência inicial do filme parte do princípio de transparência do cinema narrativo e vai progressivamente revelando seu dispositivo. Os papéis trocam de atores, os raccords já não fluem tão bem, o regime de campo e contracampo passa a atuar dentro do mesmo quadro através do procedimento de split screen, o feedback sonoro se revela intra e extradiegético, o conjunto passa a não ser tão homogêneo quanto parecia.

O jazz como jogo de improvisação requer um tema, uma estrutura e variação sobre eles, além de um mood e um feeling (fatores emocionais).

Em Symbiopsychotaxiplasm o tema é a relação, em seus múltiplos aspectos de coletividade, de relação a dois, de relação com o imprevisto, com a capacidade de extrair do fluxo do mundo sua impressão viva no filme. O mood aqui é abertura, improviso; o feeling é fazer do erro um erro significante. A conjugação jazz e microfonia aproxima ruído e expressão, erro e sentido. 
Sua estrutura jazzística também abre espaço para uma polifonia ou uma polivisão, onde cada uma das vozes e visões ganha relevo sobre as outras até ceder sua vez, ou mesmo trabalham em paralelo. A variação de atores sobre o mesmo tema, a variação de abordagens ao mesmo filme, a heterogeneidade das opiniões sobre o diretor, tudo isso é uma grande improvisação.

A direção é uma regência desses núcleos improvisadores, agenciando o espaço comum de contribuição e autonomia.

A presença das câmeras e da equipe é provocadora do processo de improvisação. O filme não tem um roteiro a ser seguido, o que importa é o acontecimento que a situação de filmagem desencadeia. $\mathrm{O}$ acontecimento fílmico só pode ser suscitado pela disposição do aparato técnico e humano. 


\section{Conclusão}

Convergem dois aspectos ao ponto de vista subjetivo. Seus aspectos propriamente imagéticos e sonoros, e o aspecto contextual narrativo. Procurei deter-me em cada um deles para relacioná-los e exemplificar suas singularidades.

O ponto de vista subjetivo é caracterizado pelo contexto narrativo mas incorpora elementos propriamente imagéticos e sonoros, bem como enunciativos e pertinentes aos atos de fala do sujeito que o suporta.

No nosso entender, o ponto de vista subjetivo, ao configurar a narrativa segundo um determinado aspecto, não implica uma interlocução direta com um destinatário, mas requer uma participação do leitor ou espectador no próprio modo de leitura, percepção ou entendimento, ou não seria reconhecido como tal. Defendo que o POV subjetivo apresenta elementos e configurações propriamente imagéticas que ajudam-no distinguí-lo de outros pontos de vista não subjetivos, amparados pelo contexto narrativo que o envolve. Deste modo, o aspecto relacional determinado narrativamente, como explicita com razão Jacques Aumont, implicaria para a materialidade fílmica elementos e coordenadas que ajudariam a configurar subjetividade do ponto de vista.

A câmera subjetiva constrói uma propriocepção, uma ancoragem diegética, uma sensorialidade imersiva que se diferencia da identificação objetiva com a câmera, no discurso direto mais corrente. Em filmes como O escafandro e a Borboleta, de Julian Schnabel (2007), ou Enter the void de Gaspar Noé (2009), estabelece-se um vínculo de personificação da câmera que reflete os estados corporais da personagem. Mais que metáforas do olho da câmera, trata-se da sensorialidade do corpo-câmera regendo a lógica da consciência-câmera coalescendo na materialidade da câmera subjetiva.

Os usos contemporâneos do ponto de vista subjetivo reforçam e expandem o conceito tradicional da câmera subjetiva, proporcionando-lhe novas conotações advindas de novas tecnologias, da disseminação de câmeras e gravadores e da democratização do acesso a esses dispositivos, bem como da ostensividade da gravação e do registro audiovisual nos espaços sociais. Novas configurações narrativas, imagéticas e sonoras, que problematizam e expandem as vinculações antropomórficas comumente associadas à câmera subjetiva, são incorporadas e transformam as séries culturais nas quais o cinema se insere.

O uso sistemático da câmera subjetiva, além de romper com a normatividade da teoria de que não se sustenta como recurso narrativo sistemático, fomenta a inteligência de novas formas 
de emprego do recurso e suscita novas teorias que a desenvolvem. Outras e novas figuras de subjetividade surgem de outros meios e com outros fins, nem sempre dispostos a trabalhar (o ilusionismo ou a impressão de realidade) em uma chave verídica, quer se trate de ficção ou de documentário. Os lugares instáveis e transitórios de uma borrada zona de fronteiras móveis entre a mimesis e a invenção são propostos por novos hibridismos e novas formas, que se prestam a formação de vetores e forças que deslocam essas definições afixadas ou mesmo as suprimem, mas que, por sua vez, são passíveis de novos conceitos e catalogações. Os mockumentaries, por exemplo, falsos documentários, podem ser agrupados em uma dessas novas categorias, que se impõem por um quórum de representantes e por uma história fundadora. A figura do first person shot é outro exemplo na configuração de filmes que dispensam a narratividade como condutora de seus encadeamentos, orientando-os pela continuidade do movimento. O cinema de fluxo dilui os vínculos narrativos em prol de sensorialidades. A narratividade acaba cedendo vez para um papel cada vez mais importante da sensibilidade, da temporalidade, da descrição subjetivada, das materialidades puramente ópticas, sonoras, e cinéticas da audiovisualidade.

O emprego do ponto de vista subjetivo fomenta a abordagem singular do indivíduo, com sua parcialidade que não é necessariamente restritiva, e que, pelo contrário, pode dotar de uma riqueza vivencial o tema tratado. A possibilidade de assumir o seu ponto de vista liberta o autor de formas convencionais de discurso atreladas à responsabilidade de dar conta ou esgotar seu tema. A isto se acrescenta a importância testemunhal e a renovação de linguagem. É claro que isto não é uma regra, e vimos como determinadas formas repetitivas e estéreis também se apossam do ponto de vista subjetivo.

Isto reflete-se nas obras audiovisuais com as quais este trabalho lidou, oferecendo uma pequena amostra e uma abordagem parcial. Filmes que inserem câmeras e o próprio processo de realização em seu conteúdo e adquirem conformações próprias advindas desta inserção multiplicam-se e estabelecem parâmetros para novas produções, ampliando gêneros e revelando novos realizadores. 


\section{Referências ${ }^{75}$}

ABBAGNANO, Nicola. Dicionário de filosofia. Tradução da primeira edição coordenada e revista por Alfredo Bosi, revisão da tradução e tradução de novos textos de Ivone Castilho Benedetti. 5. ed. São Paulo: Martins Fontes, 2007.

AGAMBEN, Giorgio. O que é um dispositivo?, In: O que é o contemporâneo? e outros ensaios. Trad. Vinícius Nicastro Honesko. Chapecó: Argos, 2009.

AUMONT, Jacques. O olho interminável: cinema e pintura. Trad. Eloísa Araújo Ribeiro. 2. ed. São Paulo: Cosac Naify, 2011.

AUMONT, Jacques. A imagem. Trad. Estela dos Santos Abreu, Cláudio C. Santoro. 16. ed. Campinas: Papirus, 2012.

BAUDRY, Jean-Louis. "Cinema: Efeitos ideológicos produzidos pelo aparelho de base” (1970). In: XAVIER, Ismail. (Org.) A experiência do cinema: antologia. Trad. Vinícius Dantas. Rio de Janeiro: Graal; Embrafilme, 1983.

BERGSON, Henri. Matéria e Memória: Ensaio sobre a relação do corpo com o espírito. Trad. Paulo Neves. 2. ed. São Paulo: Martins Fontes, 1999. (coleção Tópicos)

BRANIGAN, Edward. Point of view in the cinema: a theory of narration and subjectivity in classical film. Berlin: Mouton Publishers, 1984.

BRANIGAN, Edward. Projecting a Camera: Language-Games in Film Theory. London, New York: Routledge, 2006.

CHION, Michel. A Audiovisão: som e imagem no cinema. Trad. Pedro Elói Duarte. Lisboa: Texto \& Grafia, Lda., 2011.

CASETTI, Francesco. El film y su espectador. Trad. Anna Giordano Gramegna. Madrid: Ediciones Catedra, 1989.

CASETTI, Francesco. The eye of the century: Film, experience, modernity. Trad. Erin Larkin e Jennifer Pranolo. New York: Columbia University Press, 2008.

CHIAPPINI, Ligia. O foco narrativo. 4. ed. São Paulo: Ática, 1989. (série Princípios)

75 De acordo com a Associação Brasileira de Normas Técnicas. NBR 6023. 
COUCHOT, Edmond. A tecnologia na arte: da fotografia à realidade virtual. Trad. Sandra Rey. Porto Alegre: Editora da UFRGS, 2003.

CRARY, Jonathan. Técnicas do Observador. Trad. Verrah Chamma. Rio de Janeiro: Contraponto, 2012.

DELEUZE, Gilles. A imagem-movimento. Trad. Stella Senra. São Paulo: Brasiliense, 1985.

DELEUZE, Gilles. A imagem-tempo. Trad. Eloísa de Araújo Ribeiro. São Paulo: Brasiliense, 2011.

DELEUZE, Gilles. Conversações. Trad. Peter Pál Pelbart. Rio de Janeiro: Editora 34, 1992.

EUGENI, Ruggero. First person shot. Technology and new forms of subjectivity in post-cinema landscape. Disponível em: <https://www.academia.edu/2575640/First_person_shot._Technology_ and_New_Forms_of_Subjectivity_in_Post-cinema_Landscape >. Acesso em 22 ago. 2015.

GALLOWAY, Alexander R. Gaming: essays on alghorithmic culture. London, Minneapolis: University of Minnesota Press, 2006. (Eletronics mediations)

GAUDREAULT, André; JOST, François. A narrativa cinematográfica. Brasília: UnB, 2009.

GAUDREAULT, André; MARION, Philippe. O fim do cinema?: uma mídia em crise na era digital. Trad. Christian Pierre Kasper. Campinas: Papirus, 2016.

HOCKNEY, David. David Hockney e o Conhecimento Secreto. Documentário. Disponível em: $<$ https://www.youtube.com/watch?v=7W0AKH7pWZo>. Acesso em 02 jul. 2016.

ISHERWOOD, Christopher. Goodbye to Berlin. New York: New Directions, 2012.

MACHADO, Arlindo. O sujeito na tela. São Paulo: Paulus, 2007.

MACHADO, Arlindo. Pré-cinemas e pós cinemas. $5^{\text {a }}$ ed. Campinas: Papirus, 2008.

MURCH, Walter. Num piscar de olhos: a edição de filmes sob a ótica de um mestre. Trad. Juliana Lins. Rio de Janeiro: Jorge Zahar, 2004.

NICHOLS, Bill. Introdução ao Documentário. Trad. Mônica Saddy Martins. 5. ed. Campinas: Papirus, 2005.

ODIN, Roger. De la fiction. Bruxelas: De Boeck Supérieur, 2000.

PARENTE, André. Narrativa e modernidade: Os cinemas não-narrativos do pós-guerra. Campinas: Papirus, 2000. 
PASOLINI, Pier Paolo. Empirismo herege. Lisboa, Portugal: Assírio e Alvim, 1982.

PENAFRIA, Manuela; MARTINS, Índia Mara. Org. Estéticas do Digital - Cinema e Tecnologia. Covilhã, Portugal: Livros LabCom, 2007.

PERKINSON, Justin. Random Stop - Behind the Scenes. Acessado em 19/08/2016: https:// vimeo.com/100157873>. Acesso em 19/08/2016.

PUCCI JR., Renato Luiz. O equilibrio das estrelas: filosofia e imagens no cinema de Walter Hugo Khouri. $1^{\mathrm{a}}$ ed. São Paulo: Annablume/Fapesp, 2001.

QUENDLER, Christian. Subjective Cameras Locked-in and Out-of-Body. Image [\&] Narrative, v. 15, n. 1, 2014. Acessado em 15/01/2015: http://www.imageandnarrative.be/index.php/imagenarrative/issue/view/37

RAMOS, Fernão Pessoa. A imagem-câmera. Campinas, SP: Papirus, 2012.

RICOEUR, Paul. O si-mesmo como outro. Trad. Ivone C. Benedetti. $1^{\text {a }}$ ed. São Paulo, SP: WMF Martins Fontes, 2014.

RICOEUR, Paul. Tempo e Narrativa. Vol. II. Trad. Márcia Valéria Martinez de Aguiar. 1a ed. São Paulo: Editora WMF Martins Fontes, 2010.

SCHMERKIN, Nicolas. Enter The Void - Pressbook Interview of Gaspar Noé (Pressbook 19/05/2009). Disponível em: <http://encodeur.movidone.com/getimage/6LidSK8hWIE8cY23meWOGDmL24pajiaDNld8WYX6GaAkJOUxG-RgupR_VBLv1AVNwbS0qHWmG1YQh3jNGq-0cHVjuD_of4R5RVYV5JLOPa62EKRcWBGqc_wKQxz9vIvuFfjDjLKRA7pfd2WmuswhcjXYrI9xpDvOVf9qvDegIe0-_cEkFevGwaSd9s2FexISrS6_GyLJrVH6KyjH1oSNUAPZ>. Acesso em: 22 ago. 2016.

SCHNITMAN, Dora Fried. et al. Org. Nuevos Paradigmas, Cultura y Subjetividad. Buenos Aires: Paidós, 1998.

TITÉ, Florent. Technique et esthétique de la caméra subjective. Mémoire de fin d'études et de recherche. ENS Louis Lumière, 2011.

XAVIER, Ismail. Org. A experiência do cinema: antologia. Trad. Vinícius Dantas. 1a ed. Rio de Janeiro, RJ: Graal: Embrafilme, 1983.

XAVIER, Ismail. O discurso cinematográfico: a opacidade e a transparência. $2^{\mathrm{a}}$ ed,. São Paulo: Paz e Terra, 2012. 


\section{Filmografia}

Filmes analisados

A Dama do Lago (Lady in the Lake), 1947 - Dir. Robert Montgomery

Viagem Alucinante (Enter the Void), 2009 - Dir. Gaspar Noé

Hardcore: Missão Extrema (Hardcore Henry), 2015 - Dir. Ilya Naishuller

Holocausto Canibal (Cannibal Holocaust), 1980 - Dir. Ruggero Deodato

La femme défendue, 1997 - Dir. Philippe Harel

Maníaco (Maniac), 2012 - Dir. Franck Khalfoun

Megan is Missing, 2011 - Dir. Michael Goi

O escafandro e a Borboleta (Le Scaphandre et le papillon), 2007 - Dir. Julian Schnabel O prisioneiro do passado (Dark passage), 1947 - Dir. Delmer Daves

A Tortura do Medo (Peeping Tom), 1960 - Dir. Michael Powell

Random Stop, 2014 - Dir. Benjamim Arfmann

Symbiopsychotaxiplasm, 1968 - Dir. William Greaves

\section{Filmes comentados}

A bruxa de blair (The Blair Witch Project), 1999 - Dir. Daniel Myrick, Eduardo Sánchez Como visto por um telescópio (As seen through a telescope), 1900 - Dir. George Albert Smith Eros, o deus do amor, 1981 - Dir. Walter Hugo Khouri

Janela indiscreta (Rear Window), 1954 - Dir. Alfred Hitchcock

Mônica e o desejo (Sommaren Med Monika), 1953 - Dir. Ingmar Bergman O processo de Joana D'Arc (Procès de Jeanne D'Arc), 1962 - Dir. Robert Bresson

Quero ser John Malkovich (Being John Malkovich), 1999 - Dir. Spike Jonze

VHS 2, 2013 - Dir. Simon Barrett e outros 
Filmes citados - câmera subjetiva e câmera intradiegética

A primeira noite de um homem (The Graduate), 1967 - Dir. Mike Nichols Infectado (Afflicted), 2013 - Dirs. Derek Lee e Clif Prowse Estranhos Prazeres (Strange Days), 1995 - Dir. Kathryn Bigelow Guerra Sem Cortes, (Redacted), 2007 - Dir. Brian de Palma Grandma's Reading Glass, 1900 - Dir. George Albert Smith Marcados para Morrer (End of Watch), 2012 - Dir. David Ayer O exterminador do futuro, (The Terminator), 1984 - Dir. James Cameron O médico e o monstro (Dr. Jekyll and Mr. Hyde), 1931 - Dir. Rouben Mamoulian RoboCop - O policial do futuro (Robocop), 1987 - Dir. Paul Verhoeven Unfriended (Cybernatural), 2014 - Dir. Levan Gabriadze

\section{Outros filmes citados}

Motorista de táxi (Taxi driver), 1976 - Dir. Martin Scorsese

2001, Uma odisséia no espaço (2001, A space odissey), 1968 - Dir. Stanley Kubrick 